\title{
Recent advances in the gold-catalyzed additions to C-C multiple bonds
}

\author{
He Huang, Yu Zhou and Hong Liu*
}

\section{Review}

\section{Address:}

State Key Laboratory of Drug Research, Shanghai Institute of Materia

Medica, Chinese Academy of Sciences, Shanghai 201203, China

\section{Email:}

He Huang - hhuang@mail.shcnc.ac.cn; Yu Zhou -

zhouyu@mail.shcnc.ac.cn; Hong Liu* - hliu@mail.shcnc.ac.cn

* Corresponding author

Keywords:

asymmetric addition; catalysis; gold; C-C multiple bonds; tandem reaction

\author{
Beilstein J. Org. Chem. 2011, 7, 897-936. \\ doi:10.3762/bjoc. 7.103 \\ Received: 31 March 2011 \\ Accepted: 06 June 2011 \\ Published: 04 July 2011 \\ This article is part of the Thematic Series "Gold catalysis for organic \\ synthesis". \\ Guest Editor: F. D. Toste \\ (C) 2011 Huang et al; licensee Beilstein-Institut. \\ License and terms: see end of document.
}

\begin{abstract}
$\mathrm{C}-\mathrm{O}, \mathrm{C}-\mathrm{N}$ and $\mathrm{C}-\mathrm{C}$ bonds are the most widespread types of bonds in nature, and are the cornerstone of most organic compounds, ranging from pharmaceuticals and agrochemicals to advanced materials and polymers. Cationic gold acts as a soft and carbophilic Lewis acid and is considered one of the most powerful activators of $\mathrm{C}-\mathrm{C}$ multiple bonds. Consequently, gold-catalysis plays an important role in the development of new strategies to form these bonds in more convenient ways. In this review, we highlight recent advances in the gold-catalyzed chemistry of addition of $\mathrm{X}-\mathrm{H}(\mathrm{X}=\mathrm{O}, \mathrm{N}, \mathrm{C})$ bonds to $\mathrm{C}-\mathrm{C}$ multiple bonds, tandem reactions, and asymmetric additions. This review covers gold-catalyzed organic reactions published from 2008 to the present.
\end{abstract}

\section{Review}

\section{Introduction}

Gold-catalyzed reactions have emerged as a powerful synthetic tool in modern organic synthesis. This past decade has been the boom time for homogeneous gold catalysis, which was rather limited in organic synthesis until the advantages of gold complexes as catalysts were discovered [1]. In comparison to other transition-metal catalysts, most gold-catalyzed reactions are atom-economic, remarkably mild with regard to reaction conditions, and most importantly, have a different reaction scope [2-4].
One of the most important fundamental reactions in goldcatalyzed synthesis is the addition of $\mathrm{X}-\mathrm{H}(\mathrm{X}=\mathrm{O}, \mathrm{N}, \mathrm{C})$ bonds to $\mathrm{C}-\mathrm{C}$ multiple bonds, which features diverse functional group tolerance and the easy formation of carbon-carbon and carbon-heteroatom bonds $[1,4,5]$. Furthermore, the rapid growing area of tandem reactions has allowed chemists to assemble diverse complex molecular frameworks more conveniently. Although various research efforts have led to goldcatalyzed addition reactions, the area of asymmetric addition 
has only recently been pioneered. Currently, a broad range of chiral gold catalysts (or gold combined with chiral ligands) has been developed and screened. However, only limited success has been achieved. The most notable example is the chiral BIPHEP-based catalyst, which has been successfully employed in several asymmetric cycloadditions.

Several early reviews have summarized well the progress of gold-catalyzed reactions up to 2008 [6-16]. Since then, the expansion of this field has continued unabated as evidenced by more than 500 publications to be found in the literature. Herein, we summarize the new research efforts that cover several aspects of gold-catalyzed additions to unsaturated bonds: (i) $\mathrm{X}-\mathrm{H}(\mathrm{X}=\mathrm{O}, \mathrm{N}, \mathrm{C})$ bonds to $\mathrm{C}-\mathrm{C}$ multiple bonds; (ii) tandem reactions; and (iii) gold-catalyzed asymmetric additions. The literature published from 2008 up to the February of 2011 is covered. Only the most important recent studies have been selected to demonstrate the significance of gold catalysis.

\section{Gold-catalyzed C-O bond formations}

The carbon-oxygen bond is one of the most widespread types of bonds in nature. Gold catalytic addition of oxygen nucleophiles to electronically non-activated $\mathrm{C}-\mathrm{C}$ multiple bonds represents an attractive approach to the synthesis of functionalized ethers and ketones. In particular, the intramolecular addition of oxygen nucleophile to $\mathrm{C}-\mathrm{C}$ multiple bonds has become a very effective tool in the synthesis of oxygen heterocycles from readily available starting materials [11].

\subsection{Alcohols, phenols and epoxides as nucleophiles}

In general, dihydrofuran analogs can be constructed from alkynes by palladium-catalyzed intramolecular hydroalkoxylation reactions. However, the more common way to synthesize dihydrofurans is the gold catalyzed cyclization of vinyl allenols [17]. For instance, hydroxyallenic esters 1 can be selectively transformed into 2-alkyl- and 2-aryl-3-ethoxycarbonyl-2,5dihydrofurans 2 by $\mathrm{Ph}_{3} \mathrm{PAuCl}$ and AgOTf through intramolecular hydroalkoxylation via a 5-endo mode [18]. Gold(III) chloride in catalytic amounts activates 3,4,6-tri- $O$-acetyl-D-glucal, 3,4,6-tri- $O$-acetyl-D-galactal, and 3,4-di- $O$-acetyl-L-rhamnal 3 efficiently. The activated species can be employed in the Ferrier reaction with different nucleophiles at ambient conditions to yield the unsaturated derivatives 4 (Scheme 1) [19].

The intramolecular addition of a hydroxy group to a carbon-carbon triple bond is an effective strategy to construct furan analogues. Du et al. reported a highly efficient Au-catalyzed cyclization of $(Z)$-enynols that proceeded under mild reaction conditions. This methodology provided rapid access to substituted furans 6 and stereo-defined ( $Z$ )-5-ylidene2,5-dihydrofurans 7 in a regioselective manner from suitably

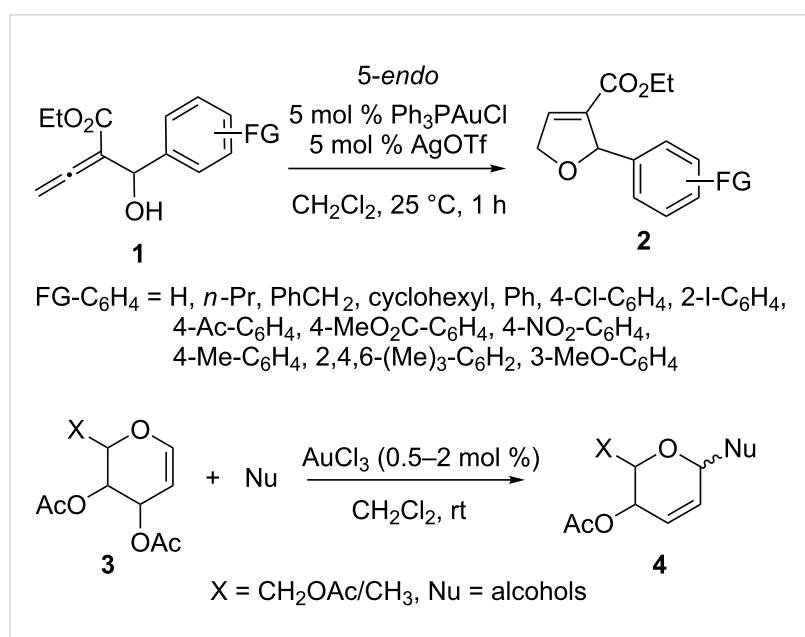

Scheme 1: Gold-catalyzed addition of alcohols.

substituted (Z)-2-en-4-yn-1-ols 5 [20]. A similar strategy has been applied to an efficient formation of substituted furans 9 through gold-catalyzed selective cyclization of enyne-1,6-diols 8 [21]. Nucleophilic attack of the hydroxy oxygen atom on 1-position to a gold-coordinated $\mathrm{C}-\mathrm{C}$ triple bond formed the vinyl-gold complex. Surprisingly, no other cyclic compound formed by nucleophilic attack of the hydroxy oxygen atom on C-6-position to a gold-coordinated $\mathrm{C}-\mathrm{C}$ triple bond was formed. A new efficient route to furans $\mathbf{1 1}$ by gold-catalyzed intramolecular nucleophilic attack of readily available heteroatom-substituted propargyl alcohols $\mathbf{1 0}$ has been developed by Aponick and co-workers [22]. For the formation of tetrahydropyran analogs 13 and 15, the gold(I)-catalyzed cyclization of monoallylic diols 12 and $\mathbf{1 4}$ is an efficient method (Scheme 2) [23,24].

In addition to common organic solvents, an attractive alternative is the use of ionic liquids as the reaction solvent, which often affords inexpensive, recyclable (and therefore environmentally benign), and sustainable catalyst systems. For example, Aksin et al. demonstrated that ionic liquids were highly suitable reaction media for the gold-catalyzed cycloisomerization of $\alpha$-hydroxyallenes 16 to 2,5-dihydrofurans 17 (Scheme 3) [25]. The best system was found to be $\mathrm{AuBr}_{3}$ in $[\mathrm{BMIM}]\left[\mathrm{PF}_{6}\right]$. The cycloisomerization of various alkyl- or arylsubstituted $\alpha$-hydroxyallenes gave corresponding 2,5-dihydrofuran with complete axis-to-center chirality transfer.

Rüttinger et al. reported a gold-catalyzed synthetic route for the preparation of enynes (Scheme 4) [26]. The gold-catalyzed cyclization provided the corresponding exo-enol ethers 19 in moderate to high yield with complete regioselectivity. By contrast, Wilckens et al. reported the gold-catalyzed endocyclizations of 1,4-diynes $\mathbf{2 0}$ to seven-membered ring heterocycles 21 [27]. The cyclization occurs exclusively in an endo- 
<smiles>[R]C#CC([R])=C([R])[R]([R])([H])C</smiles>

cat. $\mathrm{AuCl}_{3}$ or $\mathrm{PPh}_{3} \mathrm{AuOTf}$ cyclization

$\mathrm{R}^{1}=\mathrm{H}, \mathrm{CH}_{3}$

$\mathrm{R}^{2}, \mathrm{R}^{5}=\mathrm{Ph}, 4-\mathrm{MeC}_{6} \mathrm{H}_{4}, 4-\mathrm{MeOC}_{6} \mathrm{H}_{4}, 4-\mathrm{CF}_{3} \mathrm{C}_{6} \mathrm{H}_{4}, 4-\mathrm{ClC}_{6} \mathrm{H}_{4}, \mathrm{Pr}, \mathrm{Bu}$ $\mathrm{R}^{3}, \mathrm{R}^{4}=\mathrm{CH}_{3}, \mathrm{Pr}, \mathrm{Bu}, \mathrm{Et}, \mathrm{Ph}$<smiles>C=CCC/C=C(\C#CCC(O)c1ccccc1)C(O)c1ccccc1</smiles>

8<smiles>[R]Cc1oc([R])c([R])c1[R]</smiles>

or<smiles>[R]C=C1OC([R])([R])C([R])=C1[R]</smiles>

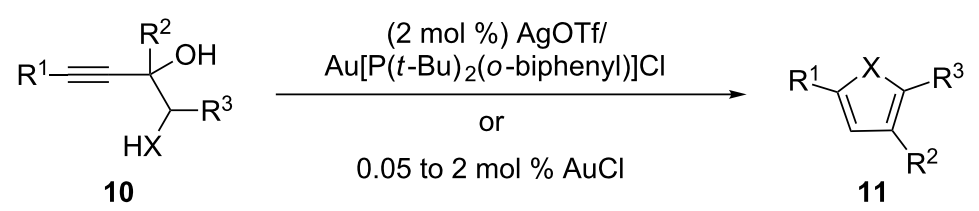

$X=O, N R, S$

$\mathrm{R}^{2}, \mathrm{R}^{3}=\mathrm{H}, \mathrm{CH}_{3}$, cyclohexyl<smiles>[R]C(O)CC=CC=CC(C)O</smiles>

12<smiles>[R]C=CC1[R17]CCCC1</smiles>

$79-99 \%$ yield

$\mathrm{R}^{1}=\mathrm{H}, \mathrm{CH}_{3}, n-\mathrm{Hex}, \mathrm{EtOCOCH} \mathrm{H}_{2}$ $\mathrm{R}^{2}=\mathrm{H}, n-\mathrm{Hex}$<smiles>[R]C(CO)N([13CH3])C/C=C/CO</smiles><smiles>CC(=O)c1ccccc1</smiles><smiles>[R]C1COC(C=C)CN1[SiH3]</smiles>

15<smiles>[R]C=C([Y4])C(O)CO[R]</smiles>

16<smiles>[R]OC1O[C@H]([R])C=C1C</smiles>

17
$\mathrm{R}^{1}=\mathrm{Me}, n-\mathrm{Bu}, \mathrm{iPr}, t-\mathrm{Bu}, \mathrm{Ph}, 2-\mathrm{MeOC}_{6} \mathrm{H}_{4}$ $\mathrm{R}^{2}=\mathrm{TBS}, \mathrm{Bn}$

Scheme 3: Ionic liquids as the solvent in gold-catalyzed cycloaddition. fashion under mild conditions and provides access to dihydrodioxepines and tetrahydrooxazepines.

The dioxabicyclo[4.2.1] ketal $\mathbf{2 3}$ and its further transformation product tetrahydropyran $\mathbf{2 4}$ were produced by an efficient gold(I) chloride catalyzed cycloisomerization of 2-alkynyl-1,5diol 22 [28]. A plausible mechanism for the gold-catalyzed transformation of dioxabicyclo[4.2.1]ketal 25 to tetrahydropyran $\mathbf{3 1}$ is outlined in Scheme 5. The gold catalyst activates one of the oxygen atoms to form the intermediates $\mathbf{2 6}$ or $\mathbf{2 7}$, 

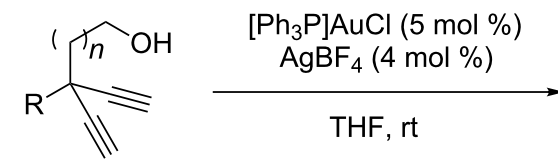

18

$\mathrm{R}=\mathrm{Ar}$, benzyl, cyclohexyl

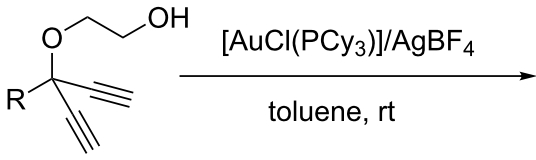

20

$\mathrm{R}=\mathrm{Ar}, \mathrm{PhCH}_{2} \mathrm{CH}_{2}$

Scheme 4: Gold-catalyzed cycloaddition of diynes.

which then rearrange to yield the oxonium intermediates $\mathbf{2 8}$ or 29, respectively.

Gold(I)-catalyzed intramolecular cyclization of monopropargylic triols $\mathbf{3 2}$ has been reported to be a novel and mild ap- proach [29] for producing olefin-containing spiroketals 33 (and enantiomer) in excellent yields (Scheme 6). A range of variously substituted triols was prepared which were cyclized to give substituted 5- and 6-membered ring spiroketals. Similarly, the synthesis of the bisbenz-annelated spiroketal core $\mathbf{3 5}$ of natural bioactive rubromycins via a gold-catalyzed double intramolecular hydroalkoxylation was reported by Zhang and co-workers [30]. A tandem cyclization mechanism was proposed by the authors.

The first example of gold-catalyzed ring-opening addition of cyclopropenes has been developed by Lee's group [31,32]. The reaction of alkyl-disubstituted cyclopropene $\mathbf{3 6}$ with a series of alcohols generated the corresponding tert-allylic ethers 37 with high regioselectivity. Gold(I) catalysts were found to be unique and superior in terms of reactivity and regioselectivity. A notable observation in some of these studies is that gold(I) catalyzed rearrangement to furanones $\mathbf{3 9}$ and indenes $\mathbf{4 0}$ is observed upon introduction of ester and phenyl substituents on the cyclopropene (Scheme 7). AuPR $\mathrm{NTf}_{2}$ complexes $\left(\mathrm{PR}_{3}=\right.$ 41-45) are selective catalysts for the intermolecular<smiles>[R1]C#CC([R2])(CCC([R4])O)C([R])O</smiles>

22

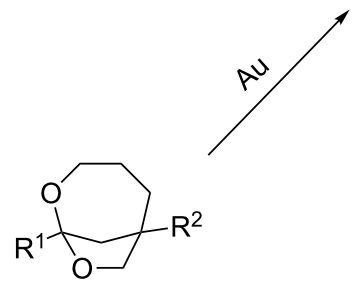

25

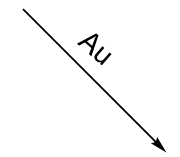

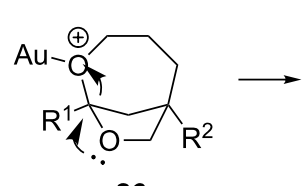

26
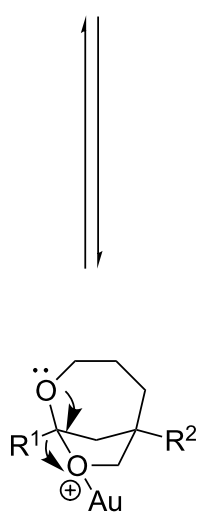

27<smiles>[R]C1CCC2([R])CC([R])(CC2[R])O1</smiles>

23

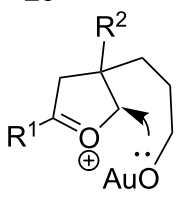

28<smiles>[R]C(=O)CC1([R])CCCOC1</smiles>

30

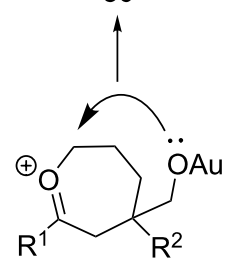

29 or<smiles>[R1]C(=O)CC1([R])CCC([R])OC1[R]</smiles>

24

$R^{1}, R^{2}=A r$, alkyl 


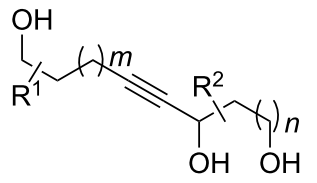

32

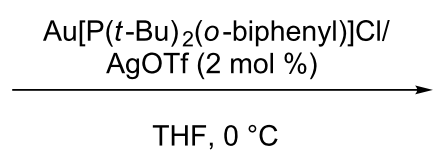

$\mathrm{THF}, 0{ }^{\circ} \mathrm{C}$

$\mathrm{R}^{1}=\mathrm{H}, \mathrm{Ph}$, cyclohexyl

$\mathrm{R}^{2}=\mathrm{H}, \mathrm{Me}$

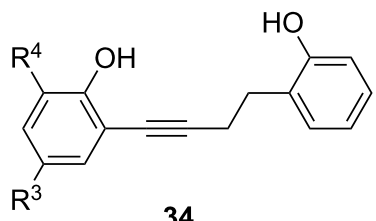

34

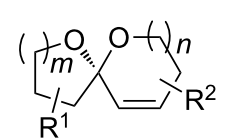

33

$\mathrm{R}^{3}=\mathrm{H}, \mathrm{Me}, t-\mathrm{Bu}, \mathrm{COMe}, \mathrm{Cl}, \mathrm{Ph}$

$\mathrm{R}^{4}=\mathrm{H}, \mathrm{OMe}$

Scheme 6: Gold-catalyzed cycloaddition of glycols and dihydroxy compounds.

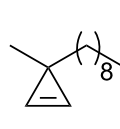

36

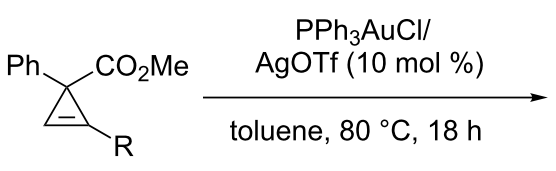

38

$\mathrm{R}=\mathrm{H}, \mathrm{TMS}, \mathrm{Ar}$

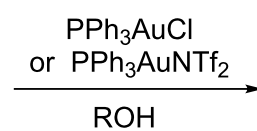<smiles>[R]C(C)(C=C)[GeH2]C</smiles>

37
Regioselective

$\mathrm{R}=$ alkyl, benzyl<smiles>[R]C1=C(c2ccccc2)C(=O)OC1</smiles><smiles>[R]C1=C(C(C)=O)c2ccccc2C1[R]</smiles>

$40,20 \%$

Scheme 7: Gold-catalyzed ring-opening of cyclopropenes.

hydroalkoxylation of electron-poor alkynes of type $\mathrm{R}-\mathrm{C} \equiv \mathrm{C}-\mathrm{EWG}$ and dimethyl acetylenedicarboxylate [33]. In reactions of phenylacetylene the ratio of vinyl ether 47 to ketal 48 can be controlled by the choice of catalyst (Scheme 8).
The gold-catalyzed intramolecular 6-endo-dig cyclization of $\beta$-hydroxy- $\alpha, \alpha$-difluoroynones $\mathbf{5 0}$ under mild conditions has been developed (Scheme 9) [34]. The result indicated that gold catalysis is compatible with electrophilic fluorinating reagents.

$$
\begin{aligned}
& \mathrm{R}^{1}=\mathrm{R}^{2} \frac{\mathrm{AuPR}_{3} \mathrm{NTf}_{2}}{\operatorname{dry~} \mathrm{CH}_{2} \mathrm{Cl}_{2}, \mathrm{rt}, 24 \mathrm{~h}} \\
& \mathrm{R}^{1} \mathrm{OR}^{3} \\
& 47 \\
& \mathrm{R}_{\mathrm{R}^{1}{ }_{48}}^{\mathrm{OR}^{3}} \mathrm{R}^{2}+\mathrm{R}_{49}^{1} \stackrel{\mathrm{O}}{\mathrm{R}^{2}} \\
& \mathrm{R}^{1}=\mathrm{Ph}, \mathrm{ClC}_{6} \mathrm{H}_{4}, \mathrm{PhOC}_{6} \mathrm{H}_{4}, \mathrm{C}_{6} \mathrm{H}_{13} \\
& \mathrm{R}^{2}=\mathrm{H}, n-\mathrm{Bu}, \mathrm{Ph} \\
& \mathrm{R}^{3}=\mathrm{Me}, \mathrm{iPr}, n-\mathrm{Bu}
\end{aligned}
$$<smiles>FC(F)(F)c1cc(C(F)(F)F)c(C(F)(F)F)c(C(F)(F)F)c1</smiles>

42<smiles>CN(C)c1ccccc1-c1ccccc1P(C)(=O)c1ccccc1</smiles>

43<smiles>COc1cccc(OC)c1-c1ccccc1P(O)O</smiles>

44<smiles>CC(C)(C)PC1CCCCC1</smiles>

45

Scheme 8: Gold-catalyzed intermolecular hydroalkoxylation of alkynes. $\mathrm{PR}_{3}=\mathbf{4 1 - 4 5}$. 
<smiles>[R]C#CC(=O)C(F)(F)C([R])O</smiles>

50

A: $5 \mathrm{~mol} \% \mathrm{AuCl}, 1.2$ equiv NIS, acetone B: $5 \mathrm{~mol} \% \mathrm{AuCl}, 1.2$ equiv NBX, $\mathrm{CH}_{2} \mathrm{Cl}_{2}$

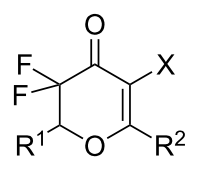

51

$X=1$ $\mathrm{X}=\mathrm{Br}$

$\mathrm{R}^{1}=\mathrm{Ph}, 4-\mathrm{CF}_{3} \mathrm{C}_{6} \mathrm{H}_{4}, 4-\mathrm{MeOC}_{6} \mathrm{H}_{4}$, cyclohexyl, $\mathrm{BnOCH}_{2}$, $\mathrm{PhCH}_{2} \mathrm{CH}_{2}$

$\mathrm{R}^{2}=\mathrm{Ph}, n-\mathrm{Pr}, \mathrm{SiMe}_{3}, \mathrm{Me}, \mathrm{Et}, \mathrm{H}$

Scheme 9: Gold-catalyzed intramolecular 6-endo-dig cyclization of $\beta$-hydroxy-a, $\alpha$-difluoroynones.

Furthermore, it is possible to couple the 6-endo-dig cyclization with iodination and bromination of the presumed vinyl-gold intermediate. However, attempted alkoxychlorination with $\mathrm{N}$-chlorosuccinimide failed. Intermolecular hydroalkoxylation of non-activated olefins catalyzed by the combination of gold(I) and electron deficient phosphine ligands has been developed [35]. Gold-catalyzed hydroalkoxylations of non-activated olefins $\mathbf{5 2}$ and simple aliphatic alcohols $\mathbf{5 3}$ gave unsatisfactory results. However, a significant improvement of reaction efficiency was observed by employing alcohol substrates bearing coordination functionalities. In addition, the catalyst system with electron deficient phosphines was also found to catalyze the desired reaction effectively (Scheme 10).

An efficient approach [36] for the preparation of unsymmetrical ethers from alcohols has been developed by utilizing

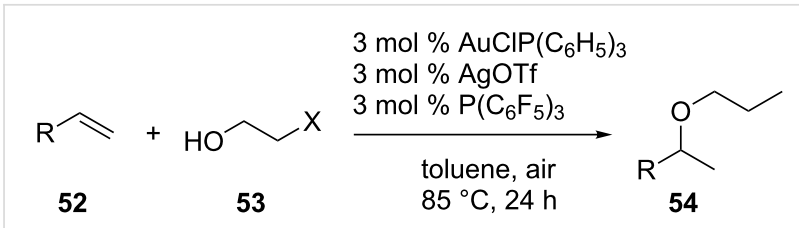

$\mathrm{X}=$ halogen or alkoxy

up to $97 \%$

Scheme 10: Gold-catalyzed intermolecular hydroalkoxylation of nonactivated olefins.

$\mathrm{NaAuCl}_{4}$. The benzylic and secondary alcohols (55 and 58) worked well under mild conditions with low catalyst loading (Scheme 11). The chiral benzyl alcohol $\mathbf{6 0}$ gave racemic ether 61, which suggested the intermediacy of a carbocation.

Ye et al. reported an expedient gold-catalyzed synthesis of dihydrofuran-3-ones 63, in which terminal alkynes 62 were used as equivalents of $\alpha$-diazo ketones to generate $\alpha$-oxo gold carbenes (Scheme 12) [37]. The $\alpha$-oxo gold carbenes were produced via gold-catalyzed intermolecular oxidation of $\mathbf{6 2}$. This provides

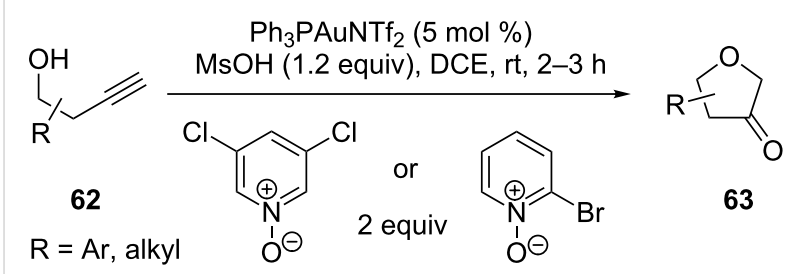

Scheme 12: Expedient synthesis of dihydrofuran-3-ones.

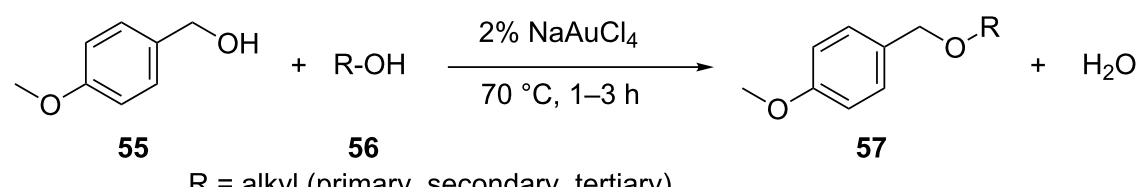

$\mathrm{R}=$ alkyl (primary, secondary, tertiary)<smiles>OC1CCc2ccccc21</smiles>

58

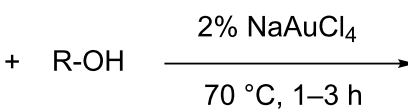

56<smiles>[R]OC1CCc2ccccc21</smiles>

59<smiles>CC(C)O[C@H]1CCc2ccccc21</smiles>

$( \pm)-61$ 
improved synthetic flexibility in comparison with the intramolecular strategy and offers a safe and economical alternative to those based on diazo substrates.

A catalytic approach to functionalized divinyl ketones through a gold-catalyzed rearrangement of (3-acyloxyprop-1ynyl)oxiranes 64 has also been developed [38]. The reaction proceeds via rearrangement of (3-acyloxyprop-1-ynyl)oxiranes to acyloxydivinyl ketones, migration of the adjacent acyloxy group, as well as cycloreversion of oxetene and provides easy access to a variety of acyloxyl divinyl ketones $\mathbf{6 5}$ (Scheme 13).

A number of interesting gold-catalyzed glycosylations have appeared in recent years. $\mathrm{Ph}_{3} \mathrm{PAuOTf}$ is reported to be a superior catalyst (yield increases by $>20 \%$ ) compared to convention-

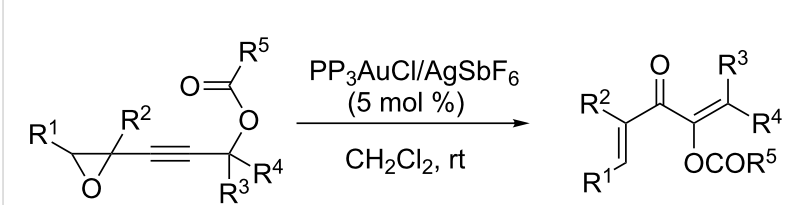

64

65

$\mathrm{R}^{3}, \mathrm{R}^{4}=\mathrm{H}, \mathrm{Ar}$, alkyl

Scheme 13: Catalytic approach to functionalized divinyl ketones.

ally used $\mathrm{ZnCl}_{2}$ for the well-established glycosylation reaction with 1,2-anhydrosugars 66 as donors (Scheme 14) [39]. The gold(I)-catalyzed reaction of 2,3,4,6-tetra- $O$-acetyl- $\alpha$-D-galactopyranosyl trichloroacetimidate $(\mathbf{6 8})$ with alcohols gave

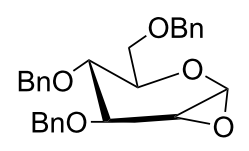

66 $\mathrm{R}=$ alkyl<smiles>CC(=O)OCC1OC(OC(=N)C(Cl)(Cl)Cl)C(OC(C)=O)C1OC(C)(C)C</smiles>

$\mathrm{R}=$ alkyl, $\mathrm{Ar}$
$\mathrm{ROH}$ ( 1.5 equiv)

$\mathrm{Ph}_{3}$ PAuOTf (0.1 equiv)

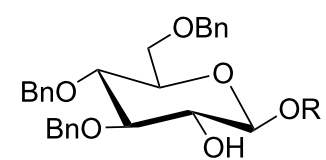

67

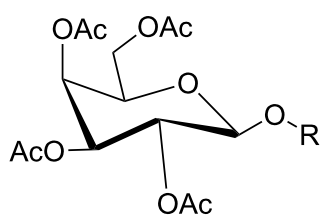

69

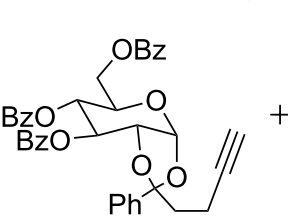

70

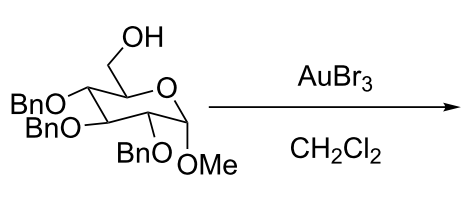

71

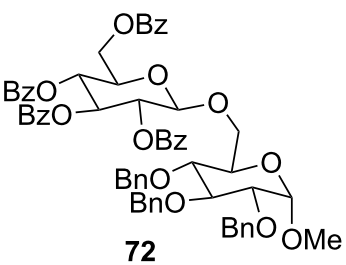<smiles>CCCCOC(=O)c1ccccc1C#C[C@H]1OCCC[C@H]1O</smiles>

73

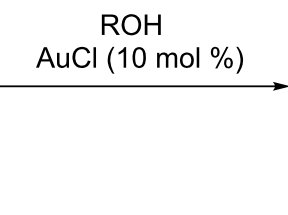

HOR

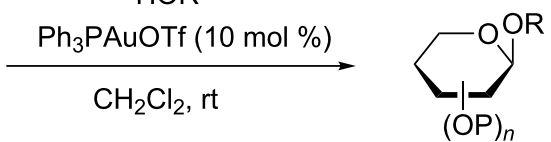

74

$\mathrm{R}=$ glucose $-6-\mathrm{OH}$ derivative and glucose- $4-\mathrm{OH}$ derivative

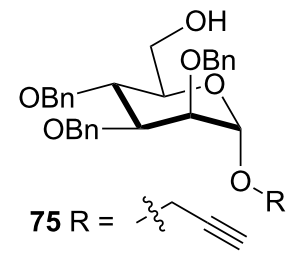

$77 \mathrm{R}=\mathrm{Me}$

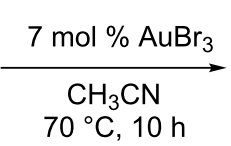

$70^{\circ} \mathrm{C}, 10 \mathrm{~h}$

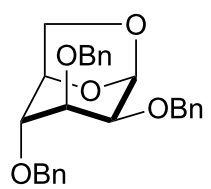

76: $71 \%$ from 76

78: $62 \%$ from 78 
$\beta$-galactosides 69 stereoselectively and in much higher yields compared to those obtained with 2,3,4,6-tetra- $O$-acetyl- $\alpha$-Dgalactopyranosyl bromide [40]. Subsequently, a method to activate the propargyl 1,2-orthoesters $\mathbf{7 0}$ selectively in the presence of propargyl glycosides and propargyl ethers was developed [41]. Recently, Li et al. reported the gold(I)-catalyzed glycosylation with glycosyl ortho-alkynylbenzoates $\mathbf{7 3}$ as donors [42] This glycosylation protocol was used in an efficient synthesis of a cyclic triterpene tetrasaccharide 74, which demonstrated its versatility and efficacy. Another study [43] showed that 1,6anhydro sugars $\mathbf{7 6}$ and $\mathbf{7 8}$ could be synthesized by utilizing salient features of gold-catalyzed glycosidations.

\subsection{Aldehydes and ketones as nucleophiles}

Different oxygen heterocycles can be obtained from the goldcatalyzed cyclization of alk-4-yn-1-ones $\mathbf{7 9}$ depending on the substitution pattern in the substrate and the reaction solvent. Thus, alkynones with one substituent at C-3 undergo a 5-exodig cycloisomerization to yield substituted furans $\mathbf{8 1}$, whilst substrates bearing two substituents at C-3 undergo a 6 -endo-dig cyclization to give $4 H$-pyrans $\mathbf{8 2}$. By contrast, alkylidene/ benzylidene-substituted tetrahydrofuranyl ethers $\mathbf{8 0}$ are formed in a tandem nucleophilic addition/cycloisomerization in alcoholic solvents [44]. Similarly, Belot et al. reported a goldcatalyzed cyclization which led to nitro-substituted tetrahydrofuranyl ethers 84 (Scheme 15) [45].

Liu et al. have developed a facile synthesis of benzochromanes $\mathbf{8 6}$ and benzobicycloacetals $\mathbf{8 7}$ from the gold-catalyzed cascade annulations of 2-(ynol)aryl aldehydes 85 [46]. Benzochro- manes were obtained when $\mathrm{AuCl}_{3}$ was employed as the catalyst, whereas benzobicyclo[5.3.1] acetals 87 were produced when triazole-gold was employed as the catalyst. With alcohol nucleophiles, gold(I)-catalyzed cyclization of $o$-alkynyl benzaldehyde $\mathbf{8 8}$ and benzaldimine-chromium complexes gave stereoselectively 1 -anti-functionalized heterocycle chromium complexes 89 (Scheme 16) [47]. This made the methodology useful for the synthesis of enantiomerically pure trans- and cis1,3-dimethylisochromans starting from a single planar chiral chromium complex.

\subsection{Carboxylates as nucleophiles}

Seraya has reported the gold-catalyzed rearrangement of cyclopropenylmethyl acetates as a route to $(Z)$-acetoxydienes [48]. Thus, treatment of 4-nitrobenzaldehyde derived cyclopropene 90 with a catalytic amount of $\mathrm{PPh}_{3} \mathrm{AuNTf}_{2}$ in DCM led to quantitative formation of acetoxy diene 91 with a $4: 1 Z: E$ selectivity within $5 \mathrm{~min}$ at $-50{ }^{\circ} \mathrm{C}$. Wang et al. developed an efficient method for the preparation of polysubstituted C-vinyl butyrolactones through a gold-catalyzed highly diastereoselective cyclization of malonate substituted allylic acetates [49]. As an example, treatment of syn-4-acetoxycyclohexenyl malonate 92 with a catalytic amount of $\mathrm{AuPPh}_{3} \mathrm{Cl} / \mathrm{AgSbF}_{6}$ in DCE at $70{ }^{\circ} \mathrm{C}$ for $3 \mathrm{~h}$ led to the isolation of 3,4-anti-4,5-syn-3-methoxycarbonyltetrahydrobenzobutyrolactone $\mathbf{9 3}$ in $80 \%$ yield. The possible intermediate is shown in Scheme 17. Using the $\mathrm{AuPPh}_{3} \mathrm{Cl} / \mathrm{AgOTf}$ system as the equivalent of $\mathrm{AuPPh}_{3} \mathrm{OTf}$, Liu et al. found that the in situ generated cationic $\mathrm{Au}(\mathrm{I})$ reagent reacted with ethyl $\alpha$-methyl- $\gamma$-cyclohexyl allenoate in dichloromethane at room temperature to form the gold complex<smiles>[R]Cc1oc([R])cc1[R1]</smiles><smiles>CC(C)C(C=O)C(C#Cc1ccccc1)C[N+](=O)[O-]</smiles>

$\mathrm{PPh}_{3} \mathrm{AuCl}(5 \mathrm{~mol} \%)$ $\mathrm{AgBF}_{4}(5 \mathrm{~mol} \%)$ $p-\mathrm{TsOH}(10 \mathrm{~mol} \%)$

$\mathrm{EtOH}(1.2$ equiv) $\mathrm{CHCl}_{3}, 0^{\circ} \mathrm{C}, 81 \%$<smiles>CCOC1O/C(=C\c2ccccc2)C(C[N+](=O)[O-])[C@H]1C(C)C</smiles>

d. r. (cis/trans): 96:4 


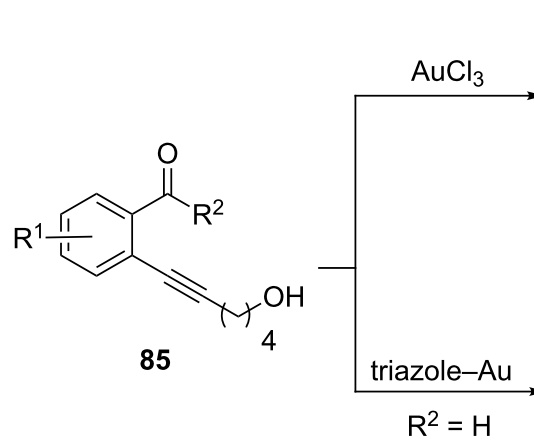

$\mathrm{R}^{1}=\mathrm{H}, 4-\mathrm{Me}, 5-\mathrm{Me}, 4,5-(\mathrm{MeO})_{2}, 5-\mathrm{F}$ $\mathrm{R}^{2}=\mathrm{H}, \mathrm{Me}, \mathrm{OMe}, \mathrm{Ph}$<smiles>[R16][R1]1ccc2cc3c(c([R])c2c1)CCCO3</smiles><smiles>[R1]1ccc2c(c1)C=C1CCCCOC2O1</smiles>

87<smiles>[R]C#Cc1c(C=O)cccc1C(=O)OCC</smiles>

88<smiles>[R1]OC1OC([R])=Cc2cc(Cl)ccc21</smiles>

89

$\mathrm{R}^{1}=\mathrm{H}, \mathrm{Me}, n-\mathrm{Bu}, \mathrm{SiMe}_{3}, \mathrm{Ph}$

$\mathrm{R}^{2}=\mathrm{Me}, \mathrm{iPr}, \mathrm{CH}_{2}=\mathrm{CHCH}_{2}, \mathrm{CH} \equiv \mathrm{CCH}_{2}$

Scheme 16: Gold-catalyzed annulations of 2-(ynol)aryl aldehydes and o-alkynyl benzaldehydes.

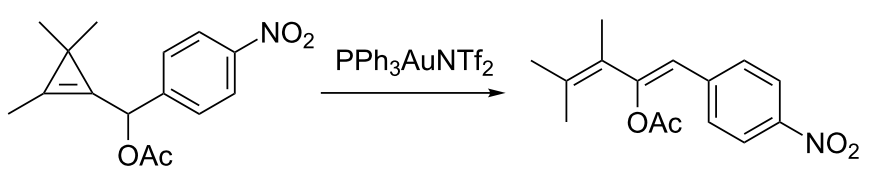

90

91

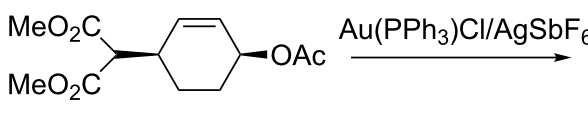

92

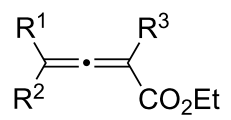

94

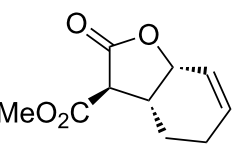

93
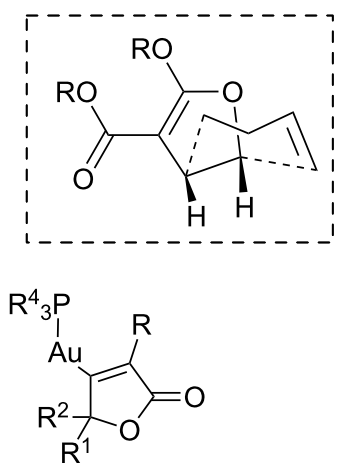

96

$\mathrm{R}^{1}=\mathrm{Me}, \mathrm{iPr}$, aryl

$\mathrm{R}^{2}, \mathrm{R}^{3}=\mathrm{H}, \mathrm{Me}$

$\mathrm{R}^{4}=\mathrm{C}_{6} \mathrm{H}_{5}, \mathrm{CH}_{3} \mathrm{C}_{6} \mathrm{H}_{4}$, cyclohexyl

Scheme 17: Gold-catalyzed addition of carboxylates.

96 in $85 \%$ yield (Scheme 17) [50]. This result could provide the experimental evidence required to support the postulated mechanism of Au-catalyzed reactions.
Dual-catalyzed rearrangement reactions have been reported by Shi and co-workers for the preparation of substituted butenolides $\mathbf{1 0 1}$ and isocoumarins [51]. In this study, the authors 
employed a carbophilic Lewis acidic $\mathrm{Au}(\mathrm{I})$ catalyst to catalyze the cross-coupling reactivity of a second Lewis basic Pd catalyst in order to functionalize vinyl-gold intermediates arising from intramolecular substrate rearrangements (Scheme 18).

\subsection{Propargylic alcohols and propargylic carboxy- late rearrangements}

Pennell et al. reported Meyer-Schuster rearrangements of propargylic alcohols $\mathbf{1 0 2}$ at room temperature in toluene with 1-2 $\mathrm{mol} \% \mathrm{PPh}_{3} \mathrm{AuNTf}_{2}$, in the presence of 0.2 equiv of 4-methoxyphenylboronic acid or 1 equiv of methanol [52].
Mechanistically, it was proposed that the enones $\mathbf{1 0 3}$ were produced through two pathways (Scheme 19).

The gold(I)-catalyzed rearrangement of propargylic tert-butyl carbonates gave diversely substituted 4-alkylidene-1,3-dioxolan-2-ones 115 [53]. For example, treatment of propargylic tertbutyl carbonate 114 with $1 \mathrm{~mol} \% \mathrm{PPh}_{3} \mathrm{AuNTf}_{2}$ in $\mathrm{CH}_{2} \mathrm{Cl}_{2}$ at room temperature led to isolation of the cyclic carbonate in $83 \%$ yield. Syntheses of oxetan-3-ones typically demand multiple synthetic steps and/or highly functionalized substrates. Alternatively, Ye et al. [54] developed a practical gold-catalyzed

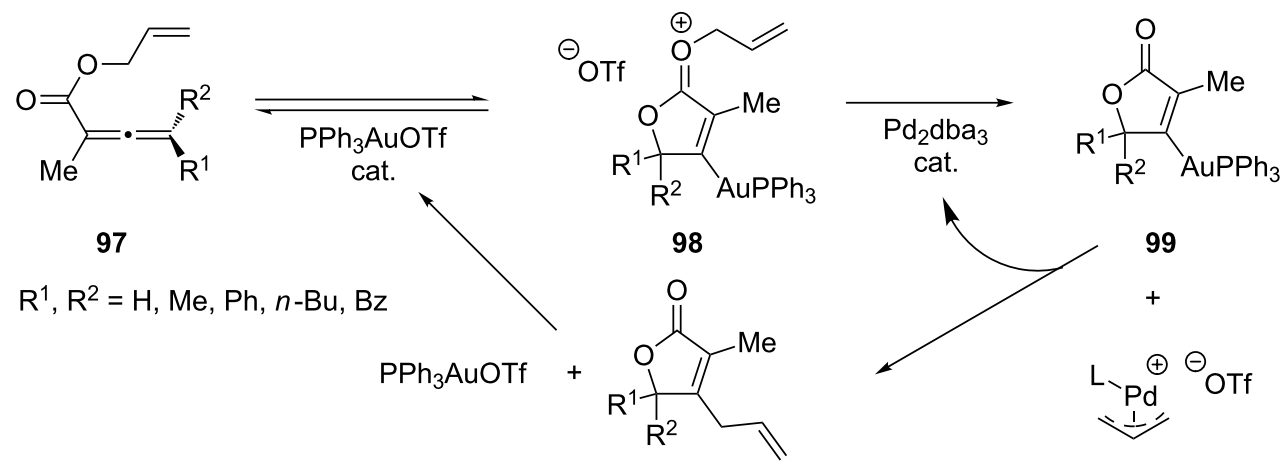

101

100

Scheme 18: Dual-catalyzed rearrangement reaction of allenoates.
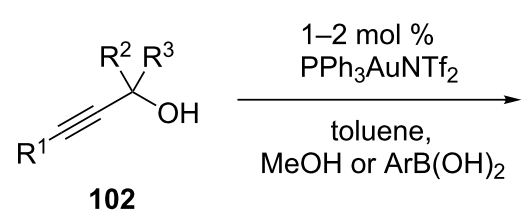

$\mathrm{R}^{1}=n-\mathrm{Bu}$,

$\mathrm{R}^{2}, \mathrm{R}^{3}=\mathrm{Me}, \mathrm{Et}, t-\mathrm{Bu}, \mathrm{iPr}$

105<smiles>[R]C#CC([R1])OOC(=O)OCC</smiles><smiles>[R]C(=O)C=C([R])[R]</smiles>

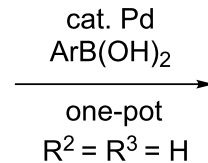

$\prod_{0}^{\mathrm{Ar}} \mathrm{T}^{1}$

104<smiles>[R]C(OB(O)[Ge])C([R])([Ge])[Ge]</smiles>

107<smiles></smiles>

111 
one-step synthesis of oxetan-3-ones $\mathbf{1 1 7}$ and $\mathbf{1 1 9}$ from readily available propargylic alcohols $\mathbf{1 1 6}$ and $\mathbf{1 1 8}$. Since chiral propargylic alcohols are readily available, this methodology provides easy access to chiral oxetan-3-ones. For example, the reaction of enantiomerically enriched secondary propargyl alcohols led to the chiral oxetan-3-one with no apparent racemization (Scheme 20).

\section{Gold-catalyzed C-N bond formations}

Many organic compounds containing nitrogen exhibit important biological and pharmaceutical properties. As with goldcatalyzed $\mathrm{C}-\mathrm{O}$ bond formation, the directly catalytic addition of a nitrogen nucleophile to a $\mathrm{C}-\mathrm{C}$ multiple bond represents an attractive approach to the formation of $\mathrm{C}-\mathrm{N}$ bonds [55]. This is a direct and efficient procedure for the synthesis of nitrogen containing compounds of industrial importance.

\subsection{Alkyl- and aromatic amines as nucleophiles}

Imines and oximes are versatile synthetic intermediates for the preparation of dyes, pharmaceuticals, and agricultural chemicals. Sun et al. have reported a multi-task Au/hydroxyapatite reagent for the heterogeneous catalyzed oxidation of alcohols and amines to imines or oximes [56]. $\mathrm{N}$-alkylation of primary amines is an important reaction in organic synthesis. He et al. developed an efficient gold-catalyzed one-pot selective $\mathrm{N}$-alkylation of amines with alcohols [57]. In their study, gold nanoparticles supported on titania act as an efficient heterogeneous catalyst for the reaction to give the $\mathrm{N}$-alkylated amines in excellent yields (Scheme 21).

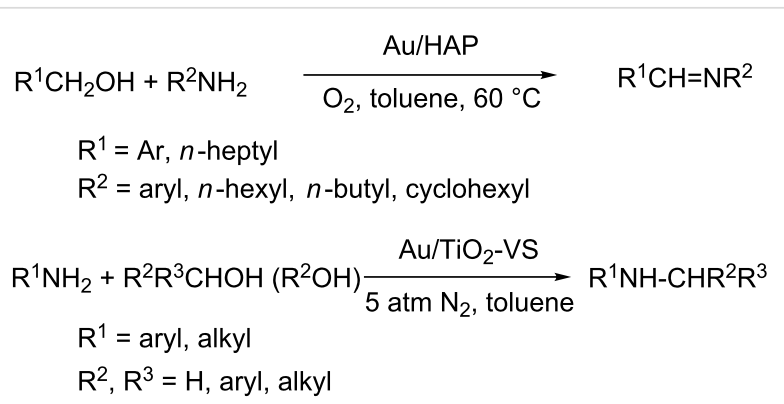

Scheme 21: Gold-catalyzed synthesis of imines and amine alkylation.

Zeng and co-workers reported that cationic gold(I) complexes promote the addition of all types of non-tertiary amines 120 to a variety of allenes $\mathbf{1 2 1}$ to afford allylic amines $\mathbf{1 2 2}$ in good to excellent yields [58]. Importantly, the Markovnikov adduct was obtained in all cases. A similar Markovnikov hydroamination [59] could also be achieved via an intermolecular hydroamination of allenamides $\mathbf{1 2 3}$ with arylamines under mild $\mathrm{AuPPh}_{3} \mathrm{OTf}$ catalysis conditions to furnish allylamino $(E)$ enamides stereoselectively (Scheme 22).

Hesp and co-workers have identified a gold pre-catalyst 125 featuring a $\mathrm{P}, \mathrm{N}-$ ligand that has significantly extended the substrate scope and synthetic utility of alkyne hydroamination [60]. The hydroamination of unsymmetrical internal aryl acetylenes $\mathbf{1 2 6}$ with dialkylamines $\mathbf{1 2 7}$ has been achieved with synthetically useful regioselectivities. In addition to intermolecular addition, Mukherjee and Widenhoefer recently reported a gold(I)(2-biphenyl) $\mathrm{Cy}_{2} \mathrm{AuNTf}_{2}(5 \mathrm{~mol} \%)$ 


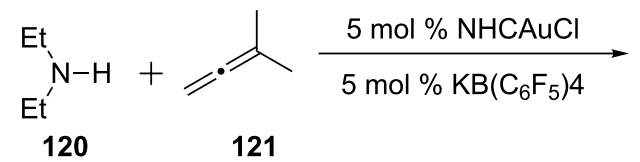<smiles>CCCl</smiles><smiles>CCN(C)C=C(C)C</smiles>

122

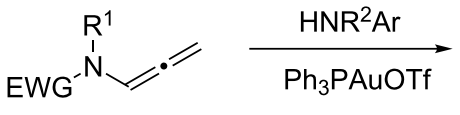

123<smiles>[R1]N(C)O[Na]</smiles>

124

$$
\mathrm{R}^{1}=\text { alkyl } \quad \mathrm{R}^{2}=\mathrm{Ar}
$$

Allylamino E-enamides

catalyzed intramolecular amination of allylic alcohols $\mathbf{1 3 0}$ with alkylamines (Scheme 23) [61].

\subsection{Imines as nucleophiles}

Gold-catalyzed cyclizations of $O$-propioloyl oximes via $\mathrm{C}-\mathrm{N}$ bond formation followed by arylidene group transfer were developed as a method for the preparation of 4-arylidene isoxazol-5(4H)-ones [62]. For example, $(E)$-benzaldehyde $O$-3phenylpropioloyl oxime 132 was reacted in acetonitrile at $25{ }^{\circ} \mathrm{C}$ in the presence of $\mathrm{AuPPh}_{3} \mathrm{NTf}_{2}$ ( $5 \mathrm{~mol} \%$ ) to give 4-benzylidene-3-phenylisoxazol-5(4H)-one $\mathbf{1 3 3}$ in 90\% yield. An efficient synthesis of multi-substituted $N$-aminopyrroles 135 via
gold(I)-catalyzed cyclization of $\beta$-allenylhydrazones $\mathbf{1 3 4}$ was developed by Benedetti and co-workers (Scheme 24) [63]. This intramolecular cyclization method can be applied to both alkylor aryl-substituted allenes and involves mild conditions and short reaction times.

\subsection{Amides, sulfamides and ureas as nucleophiles}

Using $\mathrm{AuPPh}_{3} \mathrm{Cl} / \mathrm{Ag}_{2} \mathrm{CO}_{3}$-catalyzed 5-endo-dig cyclization in water under microwave irradiation, our group developed a fast and green route to prepare indole-1-carboxamides $\mathbf{1 3 7}$ from $N$ '-substituted $N$-(2-alkynylphenyl)ureas 136 (Scheme 25) [64]. A variety of functional groups including $N^{\prime}$-aryl, alkyl, hetero-

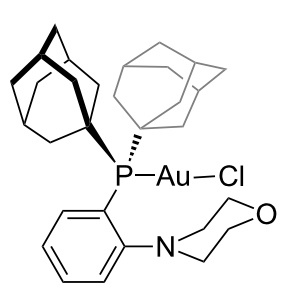

125

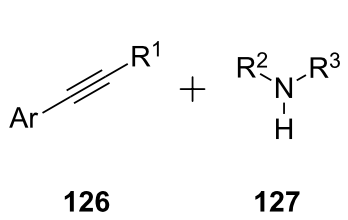

$\mathrm{R}^{1}=\mathrm{Ar}$

$\mathrm{R}^{2}, \mathrm{R}^{3}=\mathrm{Me}$, iPr, morpholine<smiles>C[C@@H](O)/C=C\CCCCNCc1ccccc1</smiles>

130

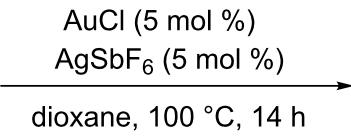

dioxane, $100{ }^{\circ} \mathrm{C}, 14 \mathrm{~h}$

$(R, Z)-12($ ee $=96 \%)$<smiles>[R]C(=[V])N([R])[R]</smiles>

128

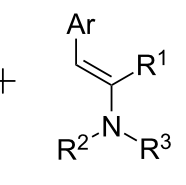

129<smiles>C/C=C/[C@H]1CCCCN1Cc1ccccc1</smiles>

131

$(R, E)-13($ ee $=96 \%)$

Scheme 23: Gold-catalyzed inter- and intramolecular amination of alkynes and alkenes. 


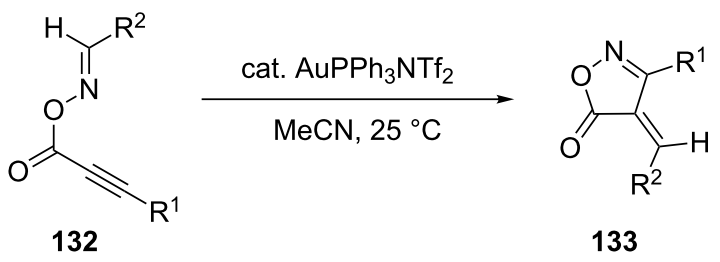

$\mathrm{R}^{1}=p-\mathrm{OMeC}_{6} \mathrm{H}_{4}, p-\mathrm{CF}_{3} \mathrm{C}_{6} \mathrm{H}_{4}, n-\mathrm{Pr}$, cyclohexyl, $t-\mathrm{Bu}, \mathrm{Ph}, p-\mathrm{MeC}_{6} \mathrm{H}_{4}$ $\mathrm{R}^{2}=\mathrm{Ph}, p-\mathrm{OMeC}_{6} \mathrm{H}_{4}, p-\mathrm{ClC}_{6} \mathrm{H}_{4}, p-\mathrm{CF}_{3} \mathrm{C}_{6} \mathrm{H}_{4}, p-\mathrm{MeC}_{6} \mathrm{H}_{4}, \mathrm{Me}$<smiles>[R]C=CC([R1])C=NN</smiles>

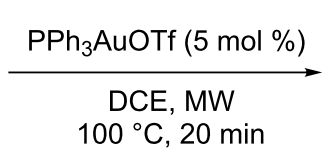<smiles>[R1]Cc1cc([R])c(N[Z17])n1[R]</smiles>

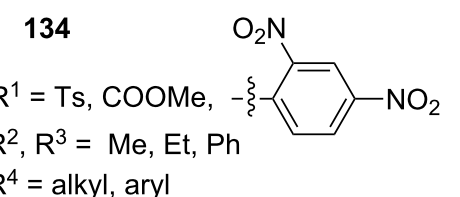

135

Scheme 24: Gold-catalyzed cycloisomerization of $O$-propioloyl oximes and $\beta$-allenylhydrazones.

cyclic, various $N$-substituted-2-ethynylphenyl and $N$-(2ethynylpyridin-3-yl)ureas, are tolerated and gives moderate to high yields of the desired products.
In another study [65], bicyclic imidazolidin-2-ones 139 were obtained via gold(I)-catalyzed intramolecular dihydroamination of allenes with $N, N^{\prime}$-disubstituted ureas $\mathbf{1 3 8}$. Iglesias et al.<smiles>[R]NC(=O)Nc1ccccc1C#C</smiles>

136 $\mathrm{R}=\mathrm{alkyl}, \mathrm{Ar}$<smiles>C=C=CCCC(CNC(=O)NBr)(c1ccccc1)c1ccccc1</smiles>

138<smiles>C=CCC(C)(C)CNC(=O)N[O+]</smiles>

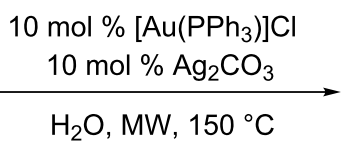

$\mathrm{H}_{2} \mathrm{O}, \mathrm{MW}, 150^{\circ} \mathrm{C}$
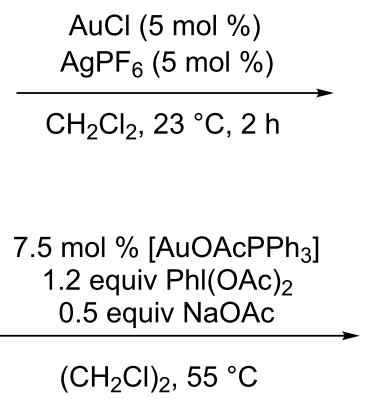

$\left(\mathrm{CH}_{2} \mathrm{Cl}\right)_{2}, 55^{\circ} \mathrm{C}$

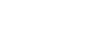<smiles>[R]NC(=O)n1ccc2ccccc21</smiles>

137<smiles>O=C1N([Al])[CH][C@H]2CCC(c3ccccc3)(c3ccccc3)CN12</smiles>

139<smiles>CC1(C)CC2C[N+](=O)C(=O)N2C1</smiles><smiles>C[C@H]1NC(=O)N1C</smiles>

142

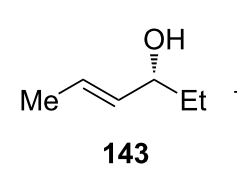

$96 \%$ ee

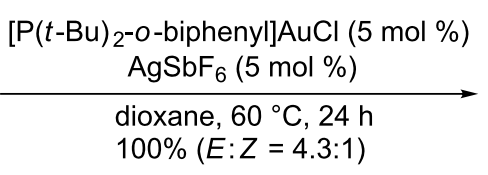

dioxane, $60^{\circ} \mathrm{C}, 24 \mathrm{~h}$

$100 \%(E: Z=4.3: 1)$

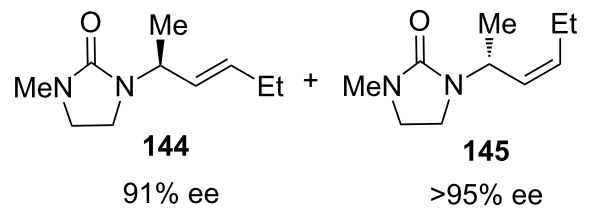

Scheme 25: Intra- and intermolecular amination with ureas. 
reported a complimentary diamination of alkenes $\mathbf{1 4 0}$ with homogeneous gold catalysts [66]. The key step is an intramolecular alkyl-nitrogen bond formation from a gold(III) intermediate. Besides the intramolecular addition of ureas, Widenhoefer's group reported a gold(I)-catalyzed intermolecular amination of allylic alcohols 143 with cyclic ureas 142 (Scheme 25) [67].

Gold-catalyzed reactions of ortho-alkynyl- $N$-sulfonylanilines 146 produced the corresponding 3-sulfonylindoles in good to high yields (Scheme 26). Nakamura and co-workers synthesized 3-mesyl-1-methyl-2-propylindole 147, 3-mesyl-1-methyl2-phenylindole 148, and 3-mesyl-1-methylindole 149 from $\mathrm{N}$-mesyl- $\mathrm{N}$-methyl-2-(1-pentynyl)aniline, $\mathrm{N}$-mesyl- $\mathrm{N}$-methyl-2(phenylethynyl)aniline, and 2-ethynyl- $N$-mesyl- $N$-ethylaniline in moderate to high yield with $\mathrm{AuBr}_{3}$ as the catalyst [68]. Surmont and co-workers later explored a similar strategy for the synthesis of 2-aryl-3-fluoropyrroles 151 [69]. Gouault et al. reported a gold-catalyzed approach to synthesize substituted pyrrolin-4-ones 153 from 1-aminobut-3-yn-2-one analogs 152 under mild conditions [70]. The use of gold(III) oxide as catalyst allows moderate to total stereo control during the cyclization.
Huang et al. has developed an efficient gold-catalyzed method to access piperidinyl enol esters 155 and piperidinyl ketones 156 under mild reaction conditions from $\varepsilon-N$-protected propargylic esters 154 [71]. This intramolecular piperidine cyclization methodology shows different reactivity and substrate applicability compared with the former intermolecular nucleophilic addition. The mechanism speculated by the authors involves a goldcatalyzed intramolecular rearrangement followed by nucleophilic attack of the Boc-protected nitrogen atom. A similar method to synthesize the 2-vinylpiperidin-3-ol 158 by a highly stereoselective gold-catalyzed allene cyclization has been reported (Scheme 27) [72].

The ring expansion of cyclopropane derivatives provides a powerful method to construct synthetically useful fourmembered carbocycles. Ye et al. reported a new type of gold(I)catalyzed ring expansion of an non-activated alkynylcyclopropane/sulfonamide to obtain (E)-2-alkylidenecyclobutanamines [73]. For example, treatment of alkynylcyclopropane 159 with $\mathrm{TsNH}_{2}$ and $5 \mathrm{~mol} \% \mathrm{PPh}_{3} \mathrm{AuCl} / 5 \mathrm{~mol} \%$ AgOTf in dichloroethane at $80{ }^{\circ} \mathrm{C}$ gave alkylidenecyclobutanamine 160 in $65 \%$ yield as a single olefin isomer (Scheme 28 ).

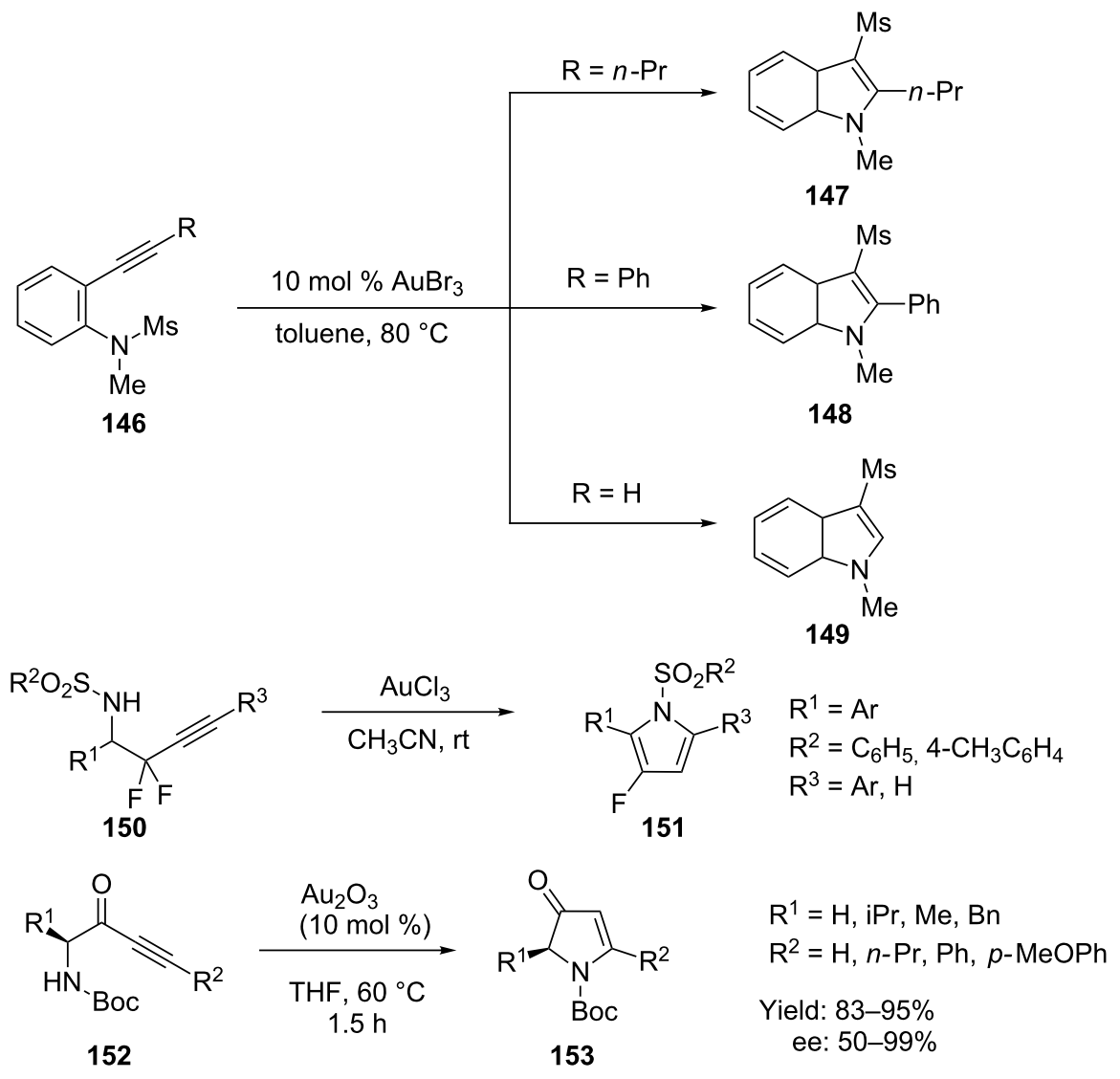

Scheme 26: Gold-catalyzed cyclization of ortho-alkynyl-N-sulfonylanilines and but-3-yn-1-amines. 

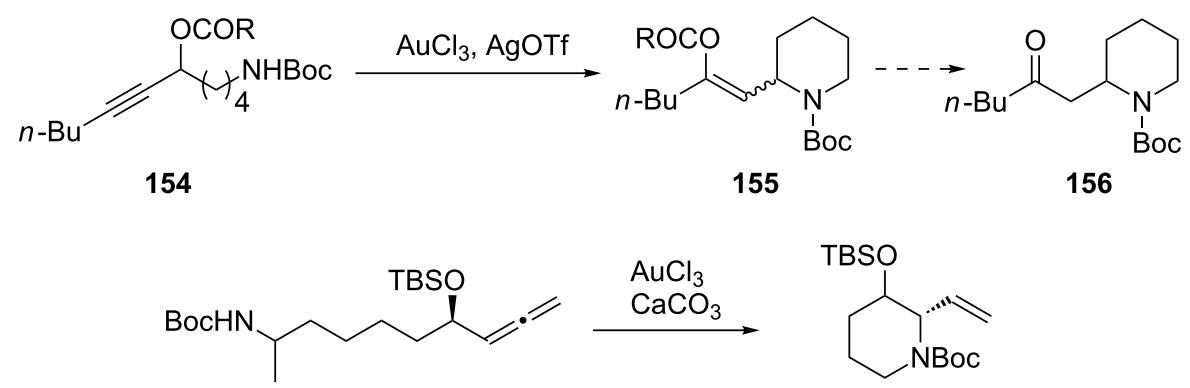

157

158

Scheme 27: Gold-catalyzed piperidine ring synthesis.

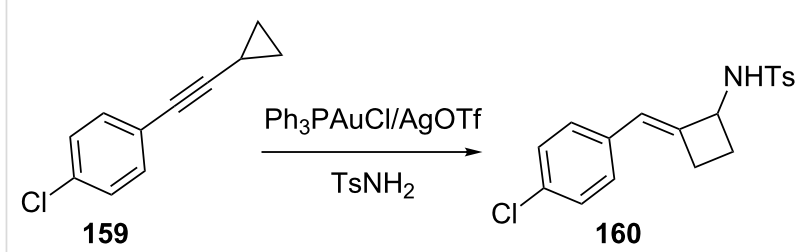

Scheme 28: Ring expansion of alkylnyl cyclopropanes.

The formation of tri- and tetrasubstituted pyrroles 163 [74] via cationic $N$-heterocyclic carbene-gold(I) complex catalyzed amino Claisen rearrangement of $N$-propargyl- $\beta$-enaminone derivatives 161 and the cyclization of $\alpha$-allenyl- $\beta$-enaminone intermediates has been developed by Saito and co-workers (Scheme 29) [75]. Toste's group has reported a novel gold(III)catalyzed [ $3+3$ ]-annulation of azomethine imines 165 with propargyl esters 164. Substitution of the $\beta$-position of the pyrazolidinone generally provides the bicyclic product 166 with high cis selectivity, which is determined during ring closing rather than in the formation of allyl-gold intermediate [76].

Gold-catalyzed cycloisomerization reaction of alkynyl aziridines 167 can give 2,5-disubstituted pyrroles 168 in high yields [77]. However, in some cases, aryl-substituted $N$-tosyl alkynyl aziridines 169 undergo a gold-catalyzed ring expansion to afford 2,5-substituted or 2,4-substituted pyrrole products [78]. Interestingly, the reaction pathway is determined by the counter ion of the gold catalyst. The formation of 2,5-substituted pyrroles 170 proceeds with $\mathrm{PPh}_{3} \mathrm{AuOTs}$ as the catalyst whilst a novel reaction pathway is accessed on changing the catalyst system to $\mathrm{PPh}_{3} \mathrm{AuOTf}$ and leads to 2,4-substituted pyrroles 171. Recently, the same group reported an efficient and selective synthesis of 2,5-substituted pyrroles 173 by goldcatalyzed ring expansion of alkynyl aziridines 172 [79]. In this study a combination of $\mathrm{Ph}_{3} \mathrm{PAuCl}$ and AgOTs generates a catalyst system that provides clean cycloisomerisation reactions.

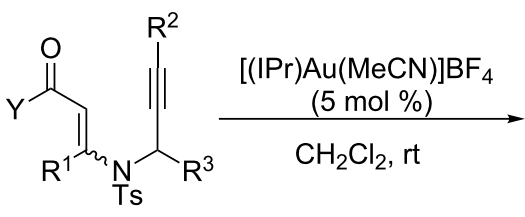

161<smiles>[R]C=C([R])C(C([R])=O)C([Y])N[As]</smiles>

162

$\mathrm{R}^{1}=\mathrm{H}, \mathrm{Ph}, \mathrm{Me}, \mathrm{COOEt} ; \mathrm{R}^{2}=\mathrm{H}, \mathrm{Me}, \mathrm{Ph}$

$\mathrm{R}^{3}=\mathrm{H}, n-\mathrm{C}_{5} \mathrm{H}_{11} ; \mathrm{Y}=\mathrm{Ar}$, alkyl<smiles>[R]C=[N+]1[R1]([O-])C(=O)C1=O</smiles>

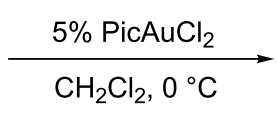

165<smiles>[R1]CN1[R1]2CCC(=O)N2C=C(OC(C)(C)C)C(C)(C)C1[R]</smiles>

166

$$
\begin{aligned}
& \mathrm{R}^{1}=\mathrm{H}, \mathrm{Me}, t-\mathrm{Bu}, \mathrm{Ph} \\
& \mathrm{R}^{2}=\mathrm{H}, \mathrm{Ar}, \text { alkyl }
\end{aligned}
$$


Similarly, $N$-Phth pyrrroles $\mathbf{1 7 5}$ are obtained via gold-catalyzed cycloisomerization of $\mathrm{N}$-Phth alkynyl aziridines $\mathbf{1 7 4}$ (Scheme 30) [80].<smiles>[R]C#CC1C([R])N1[R]</smiles>

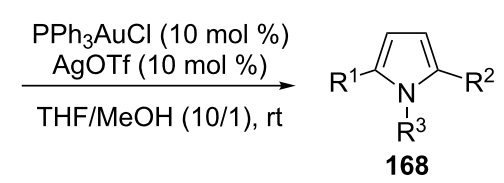

$\mathrm{R}^{1}=\mathrm{Ar}$, alkyl

$\mathrm{R}^{2}=\mathrm{Ar}$, alkyl, TMS, $\mathrm{H}$

$R^{3}=T s, M s$

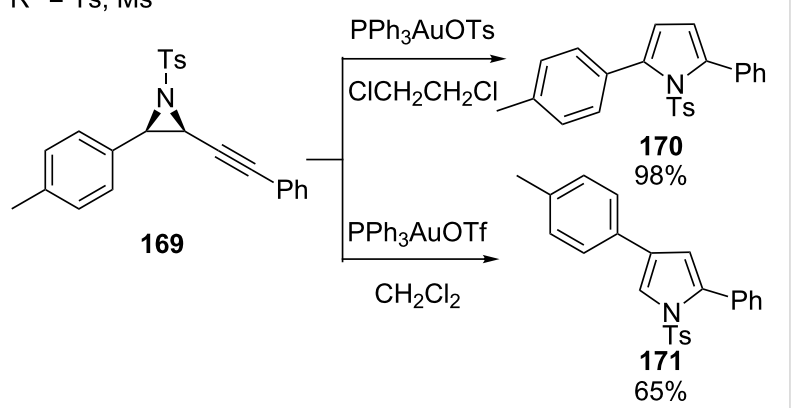<smiles>[R]C#CC1=[As]C1[R]</smiles>

$\mathrm{R}^{1}=\mathrm{Ar}$, alkyl

$\mathrm{R}^{2}=\mathrm{Ar}$, alkyl, allyl, silyl<smiles>[R]C#CC1([R])C([R])N1P</smiles>

174

$\mathrm{R}^{1}=\mathrm{CO}_{2} \mathrm{R}, \mathrm{COPh}, \mathrm{Ph} ; \mathrm{R}^{2}=$ alkyl, $\mathrm{H}$ $\mathrm{R}^{3}=\mathrm{Ar}$, alkyl; Phth $=$ phthalimidoyl

Scheme 30: Gold(I)-catalyzed cycloisomerization of aziridines.

Chan's group developed an efficient synthetic route to 1,2-dihydroquinolines 177 via $\mathrm{AuCl}_{3} / \mathrm{AgSbF}_{6}$-catalyzed intramolecular allylic amination of 2-(tosylamino)phenylprop-1-en-3-ols $\mathbf{1 7 6}$
(Scheme 31) [81]. The mechanism is suggested to involve activation of the alcohol substrate by the $\mathrm{AuCl}_{3} / \mathrm{AgSbF}_{6}$ catalyst and ionization of the starting material, which causes intramolecular nucleophilic addition of the sulfonamide unit to the allylic cation moiety and construction of a 1,2-dihydroquinoline.

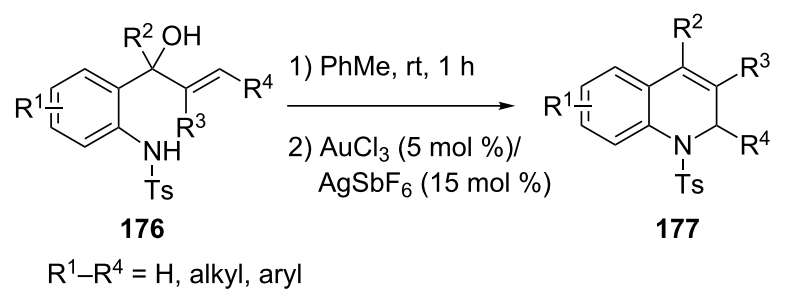

Scheme 31: $\mathrm{AuCl}_{3} / \mathrm{AgSbF}_{6}$-catalyzed intramolecular amination of 2-(tosylamino)phenylprop-1-en-3-ols.

Our group also discovered that a regioselective hydroamidation of 2-(1-alkynyl)phenylacetamides $\mathbf{1 7 8}$ could be achieved with $\mathrm{AuPPh}_{3} \mathrm{Cl} / \mathrm{AgSbF}_{6}$ as the catalyst and gave 3-benzazepin-2ones 180 via 7-endo-dig pathway [82]. Moreover, a $\mathrm{AuBr}_{3}$ mediated transformation of 2-(1-alkynyl)phenylacetamides 178 to 5-bromo-3-benzazepin-2-ones $\mathbf{1 7 9}$ was discovered, which indicated that the gold catalyst not only played an activation role but also acted as a reactant in the reaction (Scheme 32).

A simple, convenient, and green synthetic approach to diverse fused xanthines $\mathbf{1 8 2}$ has also been developed by gold-complex catalyzed intramolecular hydroamination of terminal alkynes 181 under microwave irradiation in aqueous media (Scheme 33). This transformation is atom-economical and has high functional group tolerance [83].

\subsection{Nitriles and nitrines as nucleophiles}

Ibrahim et al. reported a new and mild method for the synthesis of amide 184 from readily available benzhydrol 183 and nitriles catalyzed by a gold(I)-complex with a trimesitylene ligand [84]. Mechanistic control experiments with chiral alcohol 185 prove the intermediacy of carbenium ions. Further studies with not readily ionizable alcohols also indicate that for the benzhydrols<smiles>[R]C1=C(Br)c2ccccc2CC1=O</smiles>

179<smiles>[R]C#Cc1ccccc1CC(=O)N[R]</smiles>

178<smiles>[R]C1=Cc2ccccc2CC(=O)N1[R]</smiles>

180

$\mathrm{R}^{1}, \mathrm{R}^{2}=$ alkyl, $\mathrm{Ar}$ 
<smiles>[R][C]CCC1=NC2C(N1)C(=O)N([R1])C(=O)N2[R]</smiles>

181

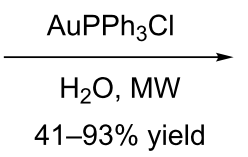

$41-93 \%$ yield<smiles>[R3]C1=CCCC2=NC3C(C(=O)N([R])C(=O)N3[R])N12</smiles>

182

$\mathrm{R}^{1}, \mathrm{R}^{2}=\mathrm{Bn}$, cyclohexylmethyl, $n-\mathrm{Bu}, n-\mathrm{Pr}, \mathrm{Et}, \mathrm{Me} ; \mathrm{R}^{3}=\mathrm{H}$

Scheme 33: Gold-catalyzed synthesis of fused xanthines.

the carbenium ions and gold(I)-hydroxy complexes are intermediates (Scheme 34). Yamamoto's group reported that intramolecular cyclization of 2-alkynylbenzyl azides $\mathbf{1 8 7}$ in the presence of $\mathrm{AuCl}_{3}$ and $\mathrm{AgSbF}_{6}$ in THF under pressure at $100{ }^{\circ} \mathrm{C}$ gives the corresponding isoquinolines $\mathbf{1 8 8}$ in good yields [85].<smiles>OC(c1ccccc1)c1ccccc1</smiles>
183<smiles>CC(O)c1ccccc1</smiles>
ee $=99.5 \%$ 185<smiles>[R]C#Cc1ccccc1C([R])N</smiles>
187

$\mathrm{R}^{1}=\mathrm{Ph}, 4-\mathrm{MeOC}_{6} \mathrm{H}_{4}, n-\mathrm{Bu}, 1$-cyclohexenyl $\mathrm{R}^{2}=\mathrm{H}, \mathrm{OAc}$, hexyl, $\mathrm{Ph}$

\section{Gold-catalyzed $\mathrm{C}-\mathrm{C}$ bond formations}

The formation of carbon-carbon bonds by using various transition metals such as $\mathrm{Pd}, \mathrm{Ni}, \mathrm{Ru}, \mathrm{Rh}$ has been extensively investigated and is well documented in the literature. Recent years have witnessed a tremendous growth in the number of gold-catalyzed highly selective chemical transformations. Although gold was considered to be an inert metal for a long time, its ability to behave as a soft Lewis acid has only been recently recognized. Such a property allows it to activate unsaturated functionalities such as alkynes, alkenes, and allenes, to create $\mathrm{C}-\mathrm{C}$ bonds under extremely mild conditions [15].
Scheme 34: Gold-catalyzed synthesis of amides and isoquinolines.

\subsection{Intermolecular coupling}

An unprecedented homogeneous gold-catalyzed oxidative cross-coupling which leads to $\alpha$-arylenones $\mathbf{1 9 0}$ from propargylic acetates 189 and arylboronic acids has been developed by Zhang's group (Scheme 35) [86]. This cross-coupling reaction reveals the synthetic potential of $\mathrm{Au}(\mathrm{I}) / \mathrm{Au}(\mathrm{III})$ catalytic cycles.

$\mathrm{Ph}_{3} \mathrm{PAuCl}(5 \mathrm{~mol} \%)$
$\mathrm{ArB}(\mathrm{OH})_{2}(4$ equiv)
$\begin{aligned} & \mathrm{Selectfluor}{ }^{\circledR} \text { (2 equiv) } \\ & \mathrm{MeCN} / \mathrm{H}_{2} \mathrm{O}=20: 1\end{aligned}$
$80^{\circ} \mathrm{C}, 15-30 \mathrm{~min}$

$\mathrm{R}^{1}=\mathrm{H}, \mathrm{Me}, \mathrm{iPr}$, cyclohexyl, Ar

$\mathrm{R}^{2}=n$-Butyl, $\mathrm{Ph}$, cyclohexyl, $\mathrm{MeOCH}_{2} \mathrm{CH}_{2}$

Scheme 35: Gold-catalyzed oxidative cross-coupling reactions of propargylic acetates.

Kimber reported a facile and mild synthesis of enamides (193-196) by a gold-catalyzed nucleophilic addition to allenamides 191 (Scheme 36) [87]. For example, treatment of

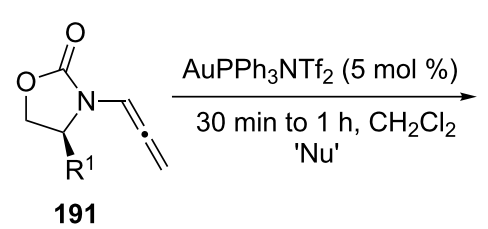<smiles>[R16]C1COC(=O)N1/C=C\CN</smiles>
$\mathrm{Nu}=$ electron rich aromatic/heteroaromatic<smiles>O=C1OCCN1/C=C/Cc1c[nH]c2ccccc12</smiles>

193 Yield $82 \%$<smiles>Cc1c(C/C=C/N2CCOC2=O)[nH]c2ccccc12</smiles>

194 Yield $56 \%$<smiles>COc1cc(OC)c(C/C=C/N2CCOC2=O)c(OC)c1</smiles><smiles>Cn1cccc1C/C=C/N1CCOC1=O</smiles>

196 Yield $42 \%$
Scheme 36: Gold-catalyzed nucleophilic addition to allenamides. 
allenamide and 1-methylindole with $5.0 \mathrm{~mol} \%$ of $\mathrm{PPh}_{3} \mathrm{AuNTf}_{2}$ in $\mathrm{CH}_{2} \mathrm{Cl}_{2}$ at room temperature gave the corresponding enamide in $83 \%$ yield.

Gold-catalyzed direct carbon-carbon bond coupling reactions have been less explored [88,89]. In 2008, Li et al. reported a gold(I) iodide catalyzed Sonogashira reaction [88]. Terminal alkynes 197 reacted smoothly with aryl iodides and bromides 198 in the presence of $1 \mathrm{~mol} \% \mathrm{AuI}$ and $1 \mathrm{~mol} \%$ dppf to generate the corresponding cross-coupling products 199 in good to excellent yields (Scheme 37). Another direct carbon-carbon bond coupling reaction was reported by Tarselli and co-workers [90]. In their study, the addition of nucleophilic methoxyarenes $\mathbf{2 0 0}$ to allenes $\mathbf{2 0 1}$ proceeded at room temperature in dichloromethane with a catalytic amount of phosphite-gold(I) pre-catalyst and a silver additive. Notably, the addition is regioselective for the allene terminus, and generates $(E)$-allylation products $\mathbf{2 0 2}$.

The direct $\mathrm{C}-\mathrm{H}$ functionalization of indoles or pyrroles is an efficient method for the introduction of vinyl and aryl groups. A gold-catalyzed direct alkynylation of indole and pyrrole heterocycles 204 with a benziodoxolone-based hypervalent iodine reagent $\mathbf{2 0 3}$ has been developed [91]. The functional group tolerance was greatly increased when compared with direct alkynylation of indoles reported previously. Kar et al. reported a general gold-catalyzed direct oxidative homo-coupling of nonactivated arenes $\mathbf{2 0 7}$ (Scheme 38). The reaction protocol toler-

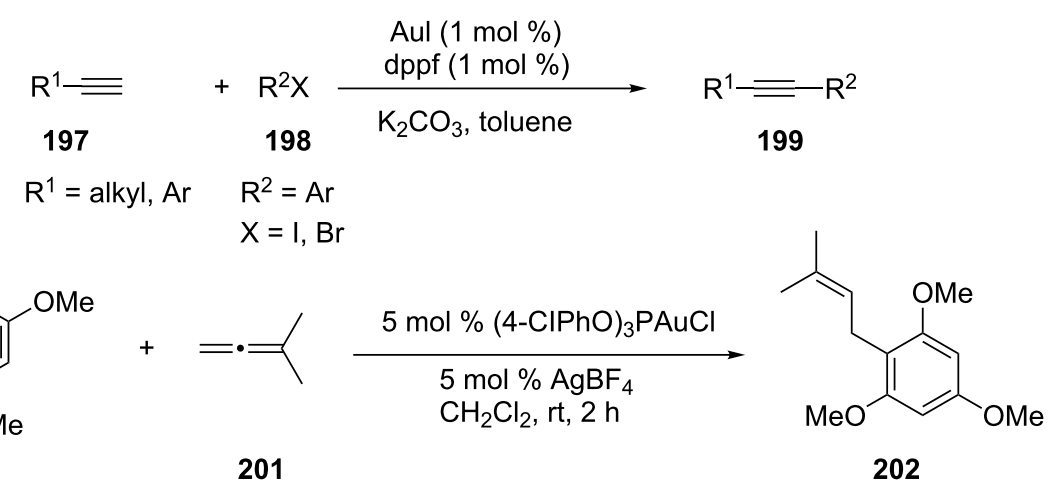

Scheme 37: Gold-catalyzed direct carbon-carbon bond coupling reactions.<smiles>O=C1OI(C#C[Se]P)c2ccccc21</smiles>

203<smiles>[R]COCC</smiles>

204

$\mathrm{R}^{1}=\mathrm{OH}, \mathrm{OMe}, \mathrm{NO}_{2}, \mathrm{CN}, \mathrm{Br}, \mathrm{I}, \mathrm{CO}_{2} \mathrm{H}$<smiles></smiles>

205 or

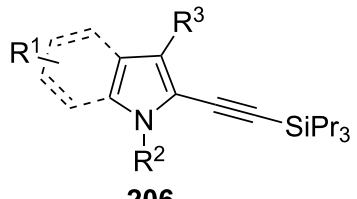

206

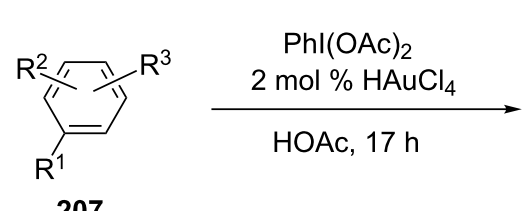

207

$\mathrm{R}^{1}, \mathrm{R}^{2}, \mathrm{R}^{3}=\mathrm{H}$, alkyl, alkoxy, cooMe

$\mathrm{R}^{2}=\mathrm{H}, \mathrm{Me} \quad \mathrm{R}^{3}=\mathrm{H}$, alkyl

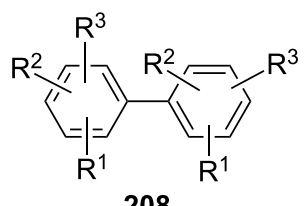

208 
ates a wide range of functional groups [92]. All halogens survive the reaction, which provides the potential for further reactions.

\subsection{Rearrangements and ring enlargement}

A gold-catalyzed rearrangement of 6-alkynylbicyclo[3.1.0]hexen-2-enes $\mathbf{2 0 9}$ has been developed [93]. In this reaction, divergent structural rearrangements are observed in the absence/presence of nucleophiles. The process results in a novel five-to-six-membered ring expansion that involves cleavage of the bridging $\mathrm{C}-\mathrm{C}$ bond and a formal [1,2]-alkynyl shift. Li et al. reported the first gold-catalyzed reaction of propargylcyclopropene systems $\mathbf{2 1 2}$ which affords benzene derivatives 213 in high yields [94] (Scheme 39).
Only few efficient methods have emerged for the synthesis of cyclobutane derivatives, which are important structural units in several natural products. Li et al. reported a novel goldcatalyzed oxidative ring-expansion of non-activated cyclopropylalkynes using $\mathrm{Ph}_{2} \mathrm{SO}$ as an oxidant [95]. Various alkynylcyclopropane derivatives $\mathbf{2 1 4}$ have been converted to cyclobutenyl ketones $\mathbf{2 1 5}$ in moderate to high yields under optimal conditions. Zou et al. has developed a versatile approach to 5-, 6-, and 7-membered carbocycles via the goldcatalyzed cycloisomerization of cyclopropyl alkynyl acetates [96]. The homo-Rautenstrauch rearrangement of 1-cyclopropylpropargylic esters 216 gave cyclohexenones 217 under mild conditions. Toste's group reported a gold(I)-catalyzed sequential cycloisomerization/ $/ \mathrm{sp}^{3} \mathrm{C}-\mathrm{H}$ bond functionalization<smiles>[R]C#CC1CC=CC=C1[R]</smiles>

$\mathrm{Au}$ (JohnPhos)Cl (1.2 mol \%) $\operatorname{AgOTf}(1.3 \mathrm{~mol} \%)$

210 $\mathrm{R}=\mathrm{Ar}$<smiles>[R]C#CC([R])([R])C1C([R])C1[R]</smiles>

212

$\mathrm{R}^{1}=\mathrm{H}$, alkyl, CN, Ph, alkynyl, alkenyl $\mathrm{R}^{2}=\mathrm{H}$, alkyl, $\mathrm{Ar}$

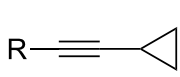

$$
\frac{[\mathrm{LAuCl}] / \mathrm{AgNTf}_{2}(5 \mathrm{~mol} \%)}{\mathrm{Ph}_{2} \mathrm{SO} \text { (5 equiv) }}
$$

214

$\mathrm{R}=\mathrm{Ar}, \mathrm{TsNMe}, \mathrm{TsN}(n-\mathrm{Pr}), \mathrm{MsNMe}, \mathrm{MsNBn}$<smiles>[R]C([R])=C([R])[C@H]1C[C@@H]1C(C)(C#C)OC(C)=O</smiles>

1) $\left[\mathrm{Au}\left(\mathrm{PPh}_{3}\right)\right] \mathrm{SbF}_{3}(1 \mathrm{~mol} \%)$ rt, $\mathrm{CH}_{2} \mathrm{Cl}_{2}$

2) $\mathrm{K}_{2} \mathrm{CO}_{3}, \mathrm{MeOH}, 30 \mathrm{~min}$

216

$\mathrm{R}^{1}, \mathrm{R}^{3}=\mathrm{H}$, alkyl, $\mathrm{R}^{2}=$ alkyl, $\mathrm{Ar}$<smiles>[R]C#CC1(CC=C)CCCCCC1</smiles>

218

\section{$\mathrm{Au}(\mathrm{JohnPhos}) \mathrm{Cl}$ (1.2 mol \%) AgOTf (1.3 mol \%) \\ $\mathrm{MeOH}$}<smiles>[R]c1c([R])c([R])c([R])c([R])c1[R]</smiles>

213
$\mathrm{R}^{3}=\mathrm{H}, \mathrm{OH}, \mathrm{OAc}$, OTMS

$\mathrm{R}^{4}=\mathrm{Ph}, n-\mathrm{Bu}$<smiles>[R]C1CCC2CCCC1C2(OC)OC</smiles>

211

$\mathrm{R}=\mathrm{H}$, alkyl, $\mathrm{Ar}, \mathrm{CHO}$ 
(Scheme 39) of 1,5-enynes 218 and 1,4-enallenes to yield tetracyclododecane $\mathbf{2 1 9}$ and tetracyclotridecane derivatives, respectively [97]. These transformations represent rare examples of $\mathrm{sp}^{3}$ $\mathrm{C}-\mathrm{H}$ bond insertion via a cationic gold(I)-carbenoid intermediate.

\subsection{Cycloadditions}

Intramolecular $[\mathrm{M}+\mathrm{N}]$-type cycloaddition reactions are powerful tools for accessing complex molecular frameworks [98]. Several gold-catalyzed [3 + 2] [99], [4 + 2] [100-105], and $[4+3]$ [106-108] cycloaddition reactions have been developed in last 3 years. Treatment of 1-aryl-1-allen-6-enes 220 with $\left[\mathrm{PPh}_{3} \mathrm{AuCl}\right] / \mathrm{AgSbF}_{6}(5 \mathrm{~mol} \%)$ in $\mathrm{CH}_{2} \mathrm{Cl}_{2}$ at $25{ }^{\circ} \mathrm{C}$ led to intramolecular [3+2] cycloadditions to afford cis-fused dihydrobenzo[ $a$ ]fluorenes $\mathbf{2 2 1}$ efficiently and selectively [99]. As pointed out by the researchers, the reactions proceeded with the initial formation of trans/cis mixtures of 2-alkyl-1-isopropyl-2phenyl-1,2-dihydronaphthalene cations, which were converted into the desired cis-fused cycloadducts through the combined action of a gold catalyst and a Brønsted acid. Gung and co-workers developed a 3,3-rearrangement/transannular [4 + 3] cycloaddition reaction (Scheme 40) in the presence of either a $\mathrm{Au}(\mathrm{I})$ or $\mathrm{Au}(\mathrm{III})$ catalyst [109]. In these reactions, the regiochemistry of the product $\mathbf{2 2 3}$ is controlled by the position of the acetoxy group in the starting material $\mathbf{2 2 2}$, while the stereochemistry of the reaction depends on the ring size.

In some gold(I)-catalyzed cycloaddition reactions, regiochemistry of the product is controlled by the ligand [100,101]. For example, the triphenylphosphinegold(I)-catalyzed reaction of allene-diene $\mathbf{2 2 4}$ provided a 2:1 mixture of the [4+3] and [4 +2] cycloadducts (225 and 226) [101]. The selectivity was improved to $96: 4$ in favor of the [4+3] cycloadduct when di-tert-butylbiphenylphosphinegold(I) was employed as the catalyst. On the other hand, the use of arylphosphitegold(I) complexes exclusively produced the formal [4+2] cycloaddition product in very good yield (Scheme 41 ).

Enynes [110-116], diynes [117-120], allenynes [121-128], and dienes [129-131] are common substrates for intramolecular cycloaddition reactions.

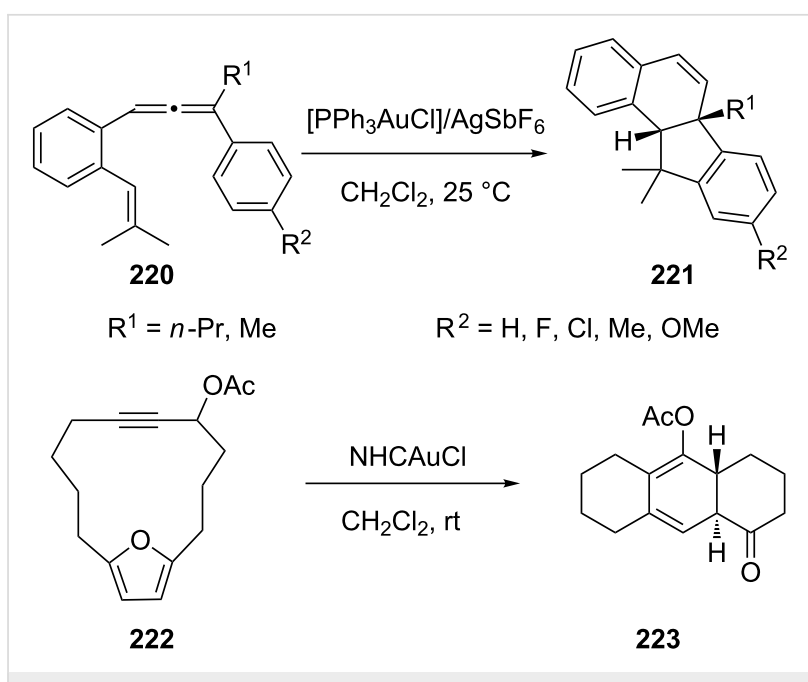

Scheme 40: Gold-catalyzed cycloaddition of 1-aryl-1-allen-6-enes and propargyl acetates.

Porcel et al. found that cationic $\mathrm{Au}(\mathrm{I})$ complexes are the most efficient catalysts for the intramolecular coupling of allyl acetates with allylstannanes (compound 227) [129]. Zhu and co-workers reported a gold-catalyzed carbocyclization of dienyl acetates 229 to construct multi-functionalized 3-vinylcyclohexanol derivatives 230 [130]. The reaction proceeded through the nucleophilic addition of the alkene to the allylic cation via a 6-endo-trig process. The structure of the substrate affected the configurational orientation of the allylic cation in a boat-like transition state, which led to either trans-cyclohexanols or cispiperidine derivatives. Some functionalized carbo- and heterocycles 232 were synthesized via gold-catalyzed cycloisomerization reactions of enynes 231 [110]. The $\mathrm{PPh}_{3} \mathrm{AuCl} / \mathrm{AgSbF}_{6}$ catalytic system promotes a Friedel-Crafts type addition of electron-rich aromatic and heteroaromatic derivatives to the non-activated alkene followed by a $\mathrm{C}-\mathrm{C}$ bond cyclization reaction. The carbon, oxygen and nitrogen tethered 1,6-enynes react smoothly with methoxy substituted benzenes, indoles, pyrroles and furans as nucleophilic partners (Scheme 42). The cycloisomerization reactions of boronated enynes $\mathbf{2 3 3}$ was achieved with gold(I) complexes generated from a mixture of gold and silver salts [111]. Both, alkynyl and alkenyl pinacol boronates were tolerated. The ratio of the different endo- and exo-prod-

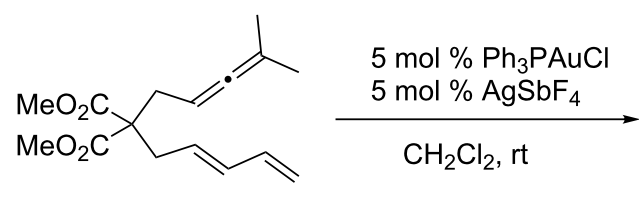

224

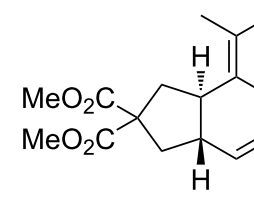

225

$225 / 226=2 / 1$ 


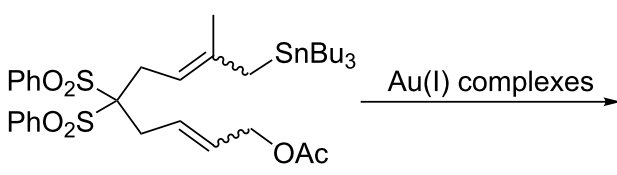

227

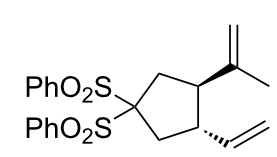

228

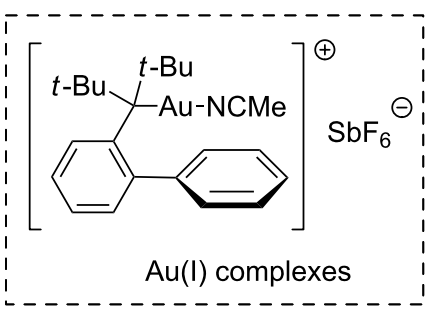<smiles>[R]C=C([R])CC/C=C\C([R])([R])O[R]</smiles>

229

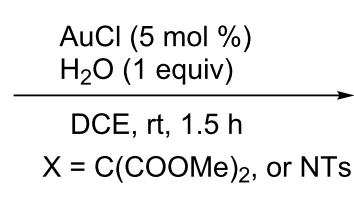

$X=\mathrm{C}(\mathrm{COOMe})_{2}$, or NTs<smiles>[R]CC([R])=CC1C[X]CC(O)(O)C1[R]</smiles>

$\mathrm{R}^{1}=\mathrm{H}, \mathrm{Me}$

$\mathrm{R}^{2}=\mathrm{H}, \mathrm{Me}$

$\mathrm{R}^{3}, \mathrm{R}^{4}=\mathrm{H}$, alkyl, Ar

230<smiles>[Z]CC=C([R])[R]</smiles>

231<smiles>COc1cc(OC)cc(OC)c1</smiles>

200

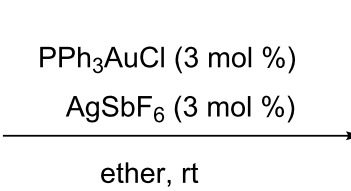

ether, rt

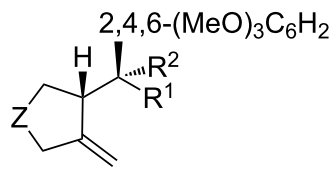

232

$$
\begin{aligned}
& \mathrm{R}^{1}, \mathrm{R}^{2}=\mathrm{H}, \mathrm{Ar} \\
& \mathrm{Z}=\mathrm{C}\left(\mathrm{CO}_{2} \mathrm{Me}\right)_{2}, \mathrm{C}\left(\mathrm{CO}_{2} \mathrm{Bn}\right)_{2}, \mathrm{C}\left(\mathrm{SO}_{2} \mathrm{Ph}\right)_{2}
\end{aligned}
$$

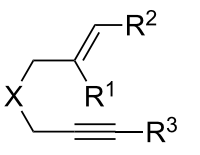

$\underset{\mathrm{AgSbF}_{6}(2 \mathrm{~mol} \%)}{\stackrel{\mathrm{PPh}_{3} \mathrm{AuCl}(2 \mathrm{~mol} \%)}{\longrightarrow}}$

233

$\mathrm{R}^{1}=\mathrm{H}, \mathrm{Me}, \mathrm{Bpin}$

$\mathrm{R}^{2}=\mathrm{H}$, Bpin

$\mathrm{R}^{3}=\mathrm{H}, \mathrm{Ph}$

$\mathrm{X}=\mathrm{C}\left(\mathrm{CO}_{2} \mathrm{Me}\right)_{2}, \mathrm{MeOCCCO}{ }_{2} \mathrm{Me}, \mathrm{NTs}$<smiles>[R]C=C([R])C1=C([R])CC([X])=C(C[R])C1</smiles>

235

Scheme 42: Gold(I)-catalyzed cycloaddition of dienes and enynes.

ucts was heavily dependent on the position of the boronate functionality (Scheme 42).

Li et al. reported a gold-catalyzed benzannulation of 3-alkoxy1,5-enynes 236 to produce functionalized benzenes 237 [112]. The reaction occurs selectively through a 6-endo-dig pathway to give tri- and tetrasubstituted benzenes efficiently. Cyclization reactions of 1,6-diynes (2,2-dipropargylmalonates 238 ) could be achieved with gold(I) catalysts. Disubstituted 1,6-diynes furnished the ( $Z$ )-cyclopentylidene derivative 239 stereoselectively [117]. Monosubstituted terminal diyne afforded the cyclopentene derivative $\mathbf{2 4 0}$, while the diterminal 1,6-diyne produced a cyclohexenone derivative 241 (Scheme 43).

Cheong and co-workers demonstrated that 1,5-allenynes $\mathbf{2 4 2}$ could be transformed to cross-conjugated trienes 243 via rearrangement with $\left[\left(\mathrm{Ph}_{3} \mathrm{PAu}\right)_{3} \mathrm{O}_{3} \mathrm{BF}_{4}\right.$ as the catalyst [121]. Computational results indicated that the ene-reaction proceeded through a unique nucleophilic addition of an allene double bond to a cationic phosphine-gold(I)-complexed phosphine-gold(I) acetylide, followed by a 1,5-hydrogen shift (Scheme 44).

A range of indole based cycloaddition products were obtained by concerting the initial regioselective site-selective indole attack (C3 position) to the $\mathrm{C}-\mathrm{C}$ multiple bonds [132-134]. In the case of gold(I)-catalyzed reactions initiated by 1,2-indole migrations [132], the starting material, indole 247, was converted to an intermediate with $\left[\operatorname{AuNTf}_{2}\left(\mathrm{Ph}_{3} \mathrm{P}\right)\right]$. Intramolecular attack of the indole on the activated alkyne gives the vinyl-gold complex, which is transformed into the gold carbene complex through a 1,2-migration of the indole. Further intramolecular nucleophilic attack of the phenyl group on the 


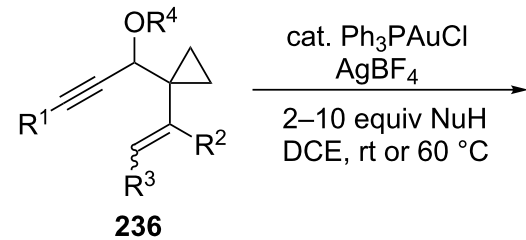

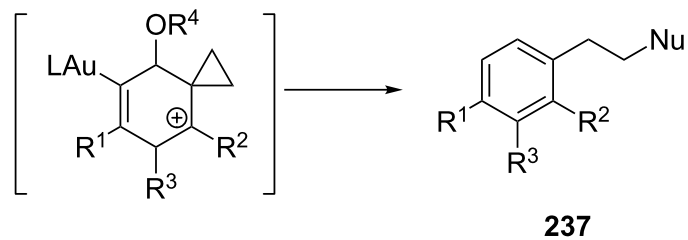

$\mathrm{R}^{1}, \mathrm{R}^{2}=$ aryl

$\mathrm{R}^{3}=\mathrm{H}$, alkyl<smiles>[R]C#CCC(CC#[R])(OC)OC</smiles>

$\underset{\mathrm{MeOH}}{\stackrel{\mathrm{AuCl}(\mathrm{L}), \mathrm{AgSbF}_{6}}{\longrightarrow}}$

238<smiles>[R]C=C1CC(OC)(OC)CC1C([R])=O</smiles>

$R^{1}, R^{2}=M e, E t, P h$

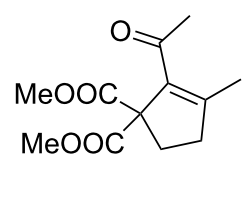

$R^{1}=M e, R^{2}=H$

240

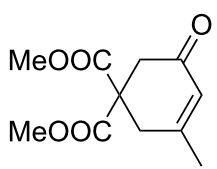

$\mathrm{R}^{1}=\mathrm{R}^{2}=\mathrm{H}$

Scheme 43: Gold-catalyzed intramolecular cycloaddition of 3-alkoxy-1,5-enynes and 2,2-dipropargylmalonates

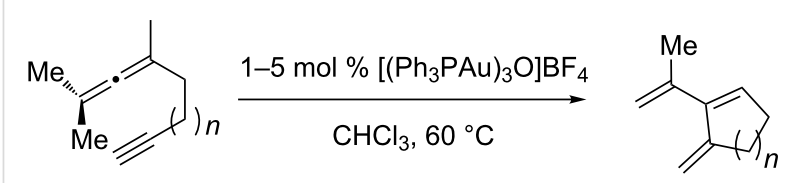

242

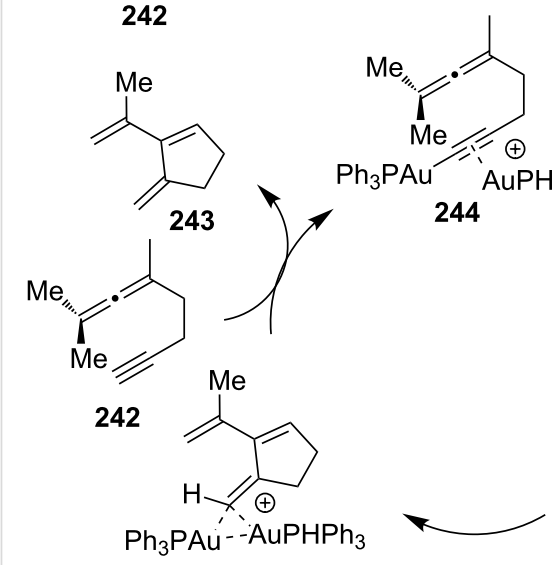

246

Scheme 44: Gold-catalyzed intramolecular cycloaddition of 1,5allenynes.

carbene carbon center, followed by a re-aromatization step and subsequent protodemetalation, affords $\mathbf{2 4 8}$ as the final product. Treatment of $N$-tethered 2,3-butadienyl- $1 H$-indole 249 with di-tert-butyl(o-biphenyl)phosphine and $\mathrm{AuNTf}_{2}$ led to 6-endo cyclization [133]. The methodology was applied in a direct synthesis of the relevant 6,9-dihydropyrido[1,2- $a]$-1H-indole core 250. A similar strategy was adopted by Ferrer and co-workers [134], who prepared the $1 H$-azocino[5,4-b]indole skeleton 252

of the lundurines by the 8-endo-dig cyclization of the alkynylindole 251 using gold(III) chloride as the catalyst (Scheme 45).

Electron-rich arenes are, in some cases, good nucleophiles $[135,136]$. An interesting gold-catalyzed electrophilic addition to an arylalkyne for the synthesis of substituted naphthalenes $\mathbf{2 5 5}$ has been developed [137]. Tarselli et al. reported a gold(I)catalyzed intramolecular hydroarylation of allenes [138]. Gold(I) complexes react with 4-allenylarenes 256 in an exo fashion to furnish vinyl-substituted benzocycles 257 . Interestingly, if 1-arylbuta-2,3-dienyl acetate $\mathbf{2 5 8}$ was used as the substrate, naphthalenes 259 are formed through a $\mathrm{AuPPh}_{3} \mathrm{Cl}$ catalyzed cyclization reaction [139]. Using gold complex [XPhosAu( $\left.\mathrm{NCCH}_{3}\right) \mathrm{SbF}_{6}$ ] as the catalyst, Jurberg and Gagosz prepared the cinnoline derivatives $\mathbf{2 6 1}$ by the hydroarylation of $N$-propargyl- $N$-arylhydrazines 260 [140]. With the gold complex $\left[\mathrm{Mes}_{3} \mathrm{PAu}\right] \mathrm{NTf}_{2}$, an alkynyl ether moiety triggered a new reaction mode of furan-yne cyclization and delivered a new class of tetracyclic system 263 rather than a phenol (Scheme 46) [141].

Insertion of a $\mathrm{C}-\mathrm{H}$ bond into a metal-carbenoid is a highly useful method for forming a new carbon-carbon bond. An atypical gold-carbenoid induced cleavage of a $\mathrm{sp}^{3}$-hybridized $\mathrm{C}-\mathrm{H}$ bond can be achieved by undergoing 1,3-addition to a vinyl-carbenoid intermediate [142]. The bicyclo[3.2.1] oct-6-en2-ones 265 and 267 could be synthesized stereoselectively by this method. Deuterium labeling experiments indicated the cyclization involved an unprecedented 1,3-addition of a $\mathrm{sp}^{3}$ hybridized $\mathrm{C}-\mathrm{H}$ bond to the vinyl-carbenoid moiety (Scheme 47). 
<smiles>[R7]C#CC([R])(c1ccc([R2])cc1)c1c([R])n([R1])c2ccc([R3])cc12</smiles>

$\stackrel{\left[\mathrm{AuNTf}_{2}\left(\mathrm{Ph}_{3} \mathrm{P}\right)\right](5 \mathrm{~mol} \%)}{\longrightarrow}$

$\mathrm{CH}_{2} \mathrm{Cl}_{2}$, rt<smiles>[R]C1=C(c2c([R])[nH]c3ccc([R])cc23)C([R])c2cc([R7])ccc21</smiles>

$248 R^{1}$

$\mathrm{R}^{1}=\mathrm{H}, \mathrm{Me}$ $\mathrm{R}^{2}=\mathrm{H}, \mathrm{Me}, \mathrm{Ph}$

$\mathrm{R}^{3}=\mathrm{H}, \mathrm{Br}, \mathrm{CO}_{2} \mathrm{Me}$

$\mathrm{R}^{5}=\mathrm{Ph}, n-\mathrm{Bu}$

$\mathrm{R}^{6}=\mathrm{H}, \mathrm{Cl}$

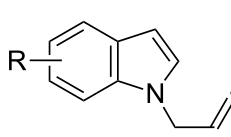

$\mathrm{R}^{4}=$ alkyl

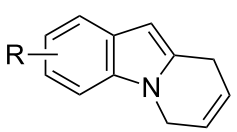

249

$\mathrm{R}=\mathrm{OMe}, \mathrm{Br}, \mathrm{Me}, \mathrm{CHO}, 4-\mathrm{MeO}-\mathrm{C}_{6} \mathrm{H}_{4}$

250

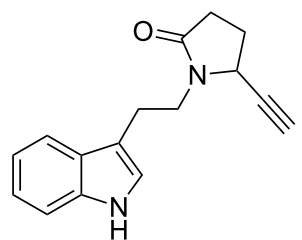

251
$\mathrm{AuCl}_{3}$<smiles>O=C1CCC2/C=C/c3[nH]c4ccccc4c3CCN12</smiles>

252

Scheme 45: Gold(I)-catalyzed cycloaddition of indoles.<smiles>[R]C(c1ccccc1)C([R])[N+](=O)[O-]</smiles>

253

$\mathrm{R}^{1}=\mathrm{H}, \mathrm{Ph}$, alkyl

$\mathrm{R}^{2}=\mathrm{H}, \mathrm{Me}, \mathrm{OEt}$

$$
254
$$

$\mathrm{R}^{3}=\mathrm{H}, \mathrm{Br}, \mathrm{Ph}, \mathrm{CH}_{2} \mathrm{OBn}$

$\mathrm{R}^{4}=\mathrm{Ph}, \mathrm{CH}_{2} \mathrm{OBn}$

\section{$\mathrm{CO}_{2} \mathrm{Me} \mathrm{CO}_{2} \mathrm{Me}$}

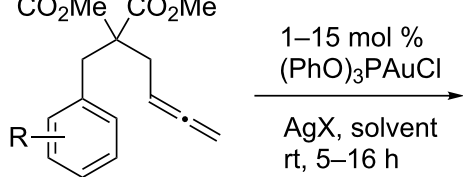

256

$\mathrm{R}=$ alkoxy, $\mathrm{Ar}$<smiles>[R]C=C=C([R])C(OC(C)=O)c1cc([R1])c([R])c([R])c1[R4]</smiles>

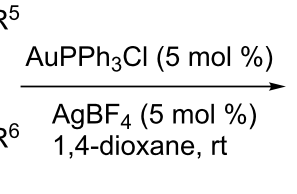

258

$\mathrm{R}^{1}=$ alkoxy; $\mathrm{R}^{2}, \mathrm{R}^{3}, \mathrm{R}^{4}=\mathrm{H}$, alkoxy

$\mathrm{R}^{5}=\mathrm{H}$, alkyl; $\mathrm{R}^{6}=\mathrm{Ar}$, alkyl<smiles>[R][14c]1ccc2c(c1)CC(C(C)=O)(C(C)=O)CC2C=C</smiles>

257<smiles>C#CCN(C(C)=O)N(c1ccccc1)c1ccccc1</smiles>

260

261

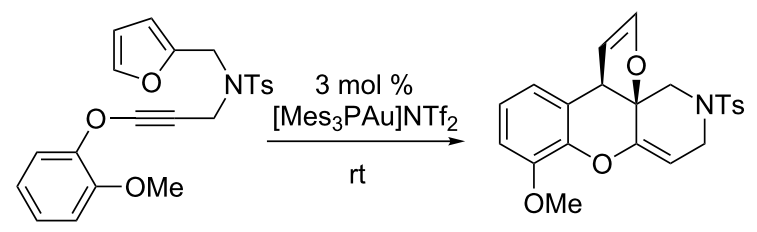

262 
<smiles>C=C(C)C(C)=C=Cc1ccccc1C(=O)OC</smiles>

$1.5 \mathrm{~mol} \%$ $\mathrm{AuCIPPh}_{3} / \mathrm{AgSbF}$ $\mathrm{DCM}, 10^{\circ} \mathrm{C}, 5 \mathrm{~min}$

2. $5 \% p$-TSA, acetone rt, 15 min

264<smiles>[2H]C(=C=C(C)C=C)c1ccccc1C(OC)(OC)OC</smiles>
O-

266

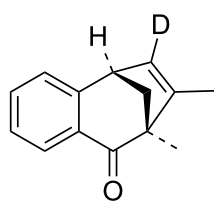

265
$1.5 \mathrm{~mol} \%$ $\mathrm{AuClPPh}_{3} / \mathrm{AgSbF}_{6}$ $\mathrm{DCM}, 10^{\circ} \mathrm{C}, 5 \mathrm{~min}$

2. $5 \% p$-TSA, acetone $\mathrm{rt}, 15 \mathrm{~min}$

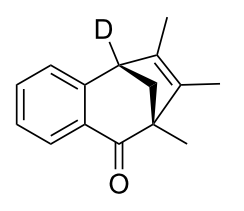

267

Scheme 47: Gold-carbenoid induced cleavage of a $\mathrm{sp}^{3}$-hybridized $\mathrm{C}-\mathrm{H}$ bond.

\section{Gold-catalyzed tandem reactions}

Tandem catalysis refers to the synthetic strategies of modular combination of catalytic reactions into one synthetic operation

with minimum workup or change in conditions [143]. The goldcatalyzed tandem reactions have allowed chemists to assemble diverse complex molecular frameworks more conveniently.

\subsection{Sequential inter-and intramolecular reactions}

Phenanthrenyl ketones are very important subunits in material science and also occur in numerous natural products. A goldcatalyzed cascade Friedel-Crafts/furan-yne cyclization/ heteroenyne metathesis was developed for the highly efficient construction of phenanthrene derivatives 270 [144]. Both $\mathrm{AuCl}_{3}$ and $\mathrm{PPh}_{3} \mathrm{AuCl}$ are effective catalysts for all the processes in the reaction and a variety of diyne substrates 271 could be used (Scheme 48). Similar strategies [145,146] were applied to synthesize arylated $(Z)$-enones, -enals or dihydrocyclohepta $[b]$ indole skeletons 277 by gold-catalyzed cascade Friedel-Crafts/furan (or indole)-alkyne cycloisomerizations (Scheme 48).

The polysubstituted butenolides $\mathbf{2 8 1}$ could be obtained through a gold-catalyzed multi-component tandem reaction that<smiles>[R]C#CC1=C(C(O)C#C[R])C[Y10]C1</smiles>

268<smiles>[R]c1ccoc1[R]</smiles>

269<smiles></smiles>

270

$\mathrm{R}^{1}, \mathrm{R}^{2}=\mathrm{Ar}$

$\mathrm{R}^{4}, \mathrm{R}^{5}=\mathrm{H}, \mathrm{Me}$

$\mathrm{R}^{3}=\mathrm{H}, \mathrm{F}$, alkoxy<smiles>[R]C#CC([R])=C([R])O</smiles>

271

$\mathrm{R}^{1}=\mathrm{Ar}$, alkyl

$\mathrm{R}^{2}=\mathrm{H}$, alkyl

$\mathrm{R}^{3}, \mathrm{R}^{4}=\mathrm{Ph}$, alky<smiles>[R]C#CC([R])=CC([R])O</smiles>

275

$\mathrm{R}^{1}=\mathrm{Ar}$, alkyl

$R^{2}, R^{3}=P h$, alkyl

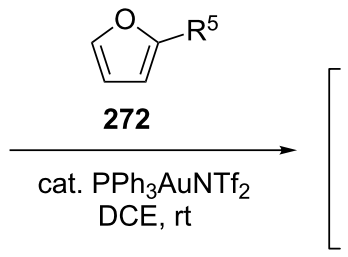

$\mathrm{R}^{5}=\mathrm{CH}_{3}, \mathrm{Ph}, \mathrm{TMS}$

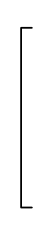

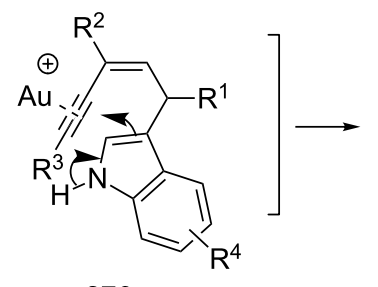

276

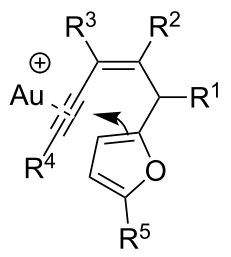

273<smiles>CC1CC1</smiles><smiles>[R]C(=O)/C=C\c1c([R])cc([R])c([R])c1[R]</smiles>

274 


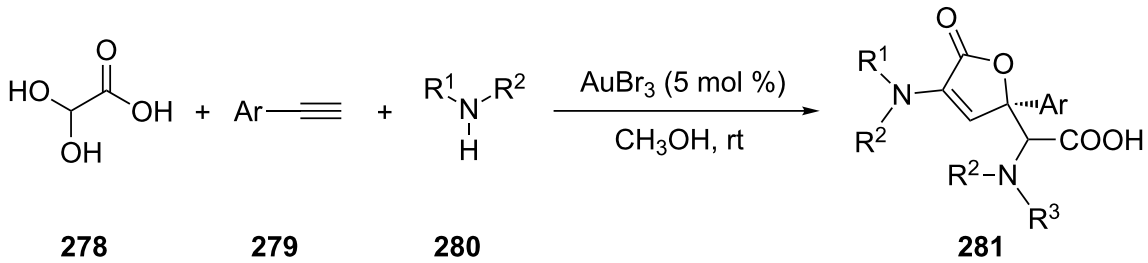

$\mathrm{R}^{1}, \mathrm{R}^{2}=$ alkyl, Bn

Scheme 49: Tandem process using aromatic alkynes.

involved novel direct alkyne 279-amine 280-glyoxylic acid (278) coupling, intramolecular cyclization of $\alpha-N$-substituted $\beta$-alkynoic acid, and subsequent reaction (Scheme 49) [147].

An intermolecular hetero-dehydro-Diels-Alder reaction between captodative 1,3-dien-5-ynes $\mathbf{2 8 2}$ and non-activated nitriles was introduced by Barluenga and co-workers [148]. The sequence is promoted by both, gold(I) and gold(III) catalysts and leads to the regioselective formation of tetrasubstituted pyridines $\mathbf{2 8 9}$. The initial coordination of the triple bond to the gold catalyst forms intermediate $\mathbf{2 8 4}$, followed by the regioselective nucleophilic attack of the nitrile, leading to the formation of 285. Cyclization may occur through resonance structure $\mathbf{2 8 6}$ or $\mathbf{2 8 7}$ followed by final metal de-coordination (Scheme 50).

\subsection{Sequential intramolecular reactions}

Sequential intramolecular reactions result in the formation of multi-ring products from a single substrate [149]. In 2010, a concise synthetic method for the generation of fused indoles (291-293), by a gold-catalyzed cascade cyclization of diynes 290 was developed by Hirano and co-workers [150]. The reaction gave aryl annulated $[a]$ carbazoles, dihydrobenzo $[g]$ indoles, and azepino- or oxepinoindole derivatives through an intramolecular cascade 5-endo-dig hydroamination followed by a 6 - or 7-endo-dig cycloisomerization. Dudnik et al. reported a gold(I)catalyzed cycloisomerization of propargylic esters 294 which led to unsymmetrically substituted naphthalenes 296 [151]. This cascade reaction involves a tandem sequence of 1,3- and 1,2migration of two different migrating groups. Jin and Yamamoto prepared the fused tri- and tetracyclic enones 298 through an<smiles>[R1][R14]=[W]</smiles>

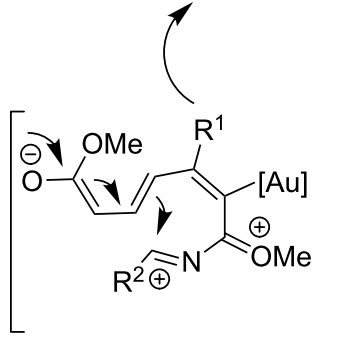

287<smiles>[R]C=NC(OC)=C([Y11])/C([R])=C\C=C\C(=O)OC</smiles>

286

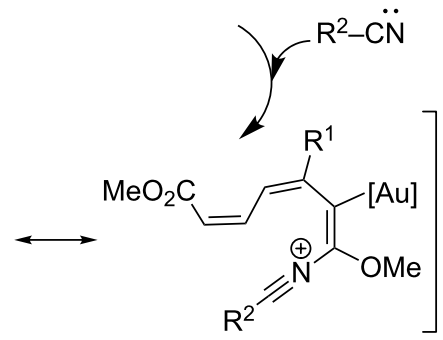

285 

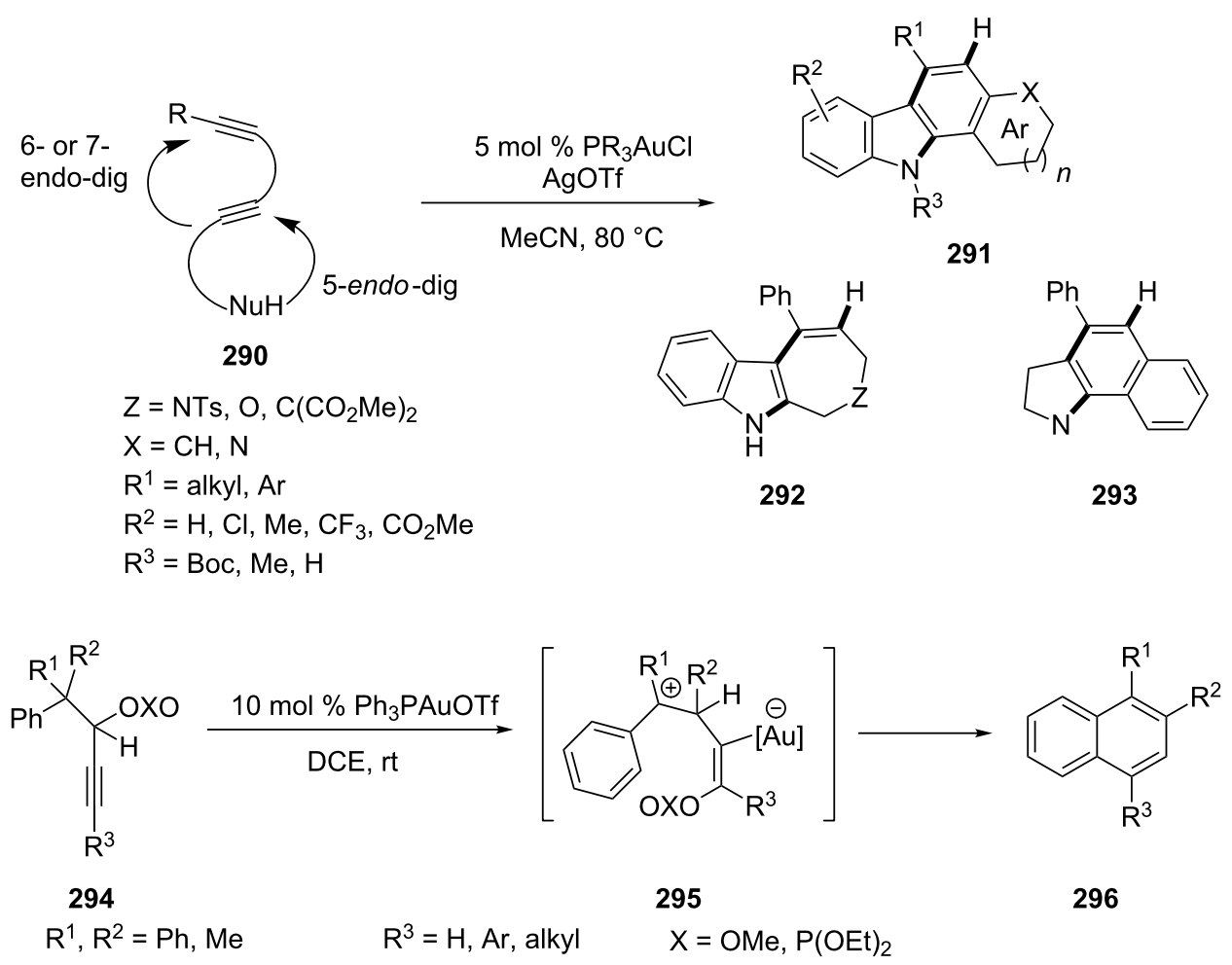

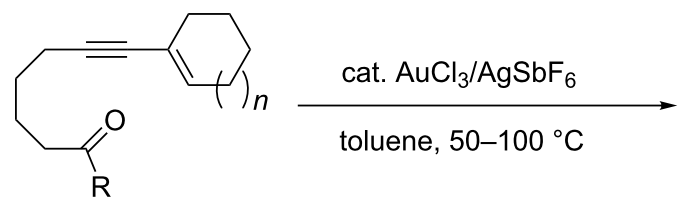

297

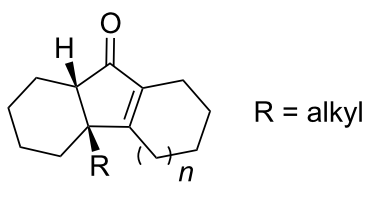

298

Scheme 51: Gold-catalyzed cascade cyclization of diynes, propargylic esters, and 1,3-enynyl ketones.

efficient gold(III)-catalyzed tandem reaction, heteroenyne metathesis, and Nazarov cyclization of 1,3-enynyl ketones 297 [152]. The gold(III) catalyst exhibits dual roles for activating both the alkyne and carbonyl moieties (Scheme 51).

More recently, Liu et al. developed a gold(III)-catalyzed tandem rearrangement/cyclization reaction of $\beta$-phenoxyimino ketone 299 (produced from $O$-arylhydroxylamines with 1,3-dicarbonyl compounds in situ) to give 3-carbonylated benzofuran derivatives 300 [153]. Trisubstituted isoxazoles $\mathbf{3 0 3}$ were obtained from alkynyl oxime ether $\mathbf{3 0 1}$ through a gold-catalyzed domino reaction involving cyclization and subsequent Claisen-type rearrangement [154]. The presence of additional substituents on the allyl moiety required an increase in catalyst loading and a prolonged reaction time for complete consumption of the substrate (Scheme 52).

Liu and Zhang have developed a gold-catalyzed region-divergent tandem cationic cyclization/ring expansion terminated by a pinacol rearrangement to produce naphthalen-2 $(1 H)$-ones or

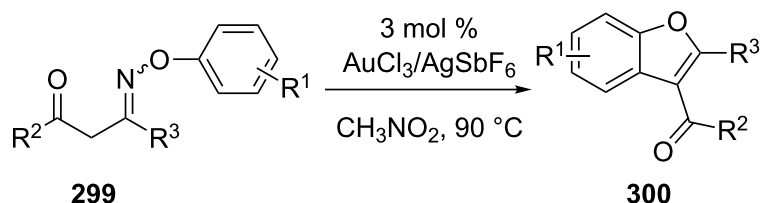

$\mathrm{R}^{1}=\mathrm{H}, \mathrm{Br}, \mathrm{Cl}, \mathrm{F}, \mathrm{Me}, \mathrm{CF}_{3}, \mathrm{CO}_{2} \mathrm{Me}$

Highly regioselective

$\mathrm{R}^{2}=$ aryl, alkyl, alkyloxy

$\mathrm{R}^{3}=$ aryl, alkyl

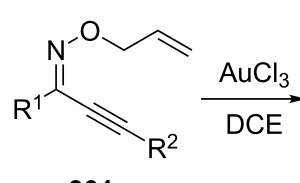

301

$\mathrm{R}^{1}=$ alkyl, $\mathrm{Ar}, \mathrm{CO}_{2} \mathrm{Me}$

$\mathrm{R}^{2}=\mathrm{Ar}$, alkyl, allyl
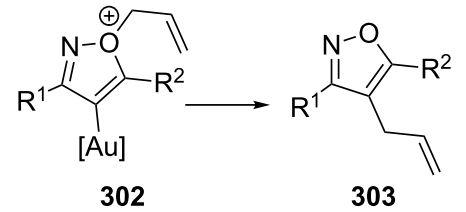

Scheme 52: Tandem reaction of $\beta$-phenoxyimino ketones and alkynyl oxime ethers. 
naphthalenes 305, 307, 309, and 311 selectively (Scheme 53) [155]. The synthesis of indole 313 [156] and tricyclic dihydroindenofuranone-type product 315 from 2-(tosylamino)phenylprop-1-yn-3-ol 312 [157] and allenoates 314 [158], respectively, has been reported (Scheme 53). The latter is the first example of a gold-catalyzed intramolecular $\mathrm{C}-\mathrm{C}$ crosscoupling reaction involving aryl $\mathrm{C}-\mathrm{H}$ functionalization with Selectfluor ${ }^{\circledR}$ as the oxidant.
2,4-Dien-6-ynecarboxylic acids 316 undergo gold-catalyzed tandem 1,6-cyclization/decarboxylation to afford 2,3-disubstituted phenols (318-321) and unsymmetrical bi- and terphenyls (Scheme 54) [159]. The reaction is greatly affected by the electronic properties of dienyne acid. The regioselective 1,6cyclization/decarboxylation sequence only takes place when a strong electron-donating group is not directly linked to the triple bond.<smiles>[R1]C#Cc1cc([R])c([R])cc1C=C([R])C(=O)c1ccccc1</smiles>

$304\left(R^{1 / R} / R^{2} / R^{4}=P h / H / C O P h\right)$

$306\left(R^{1} / R^{2} / R^{4}=\mathrm{Ph} / \mathrm{H} / \mathrm{COMe}\right)$

$308\left(R^{1 /} / R^{2} / R^{4}=1-\right.$ naphthyl/H/COPh)

$310\left(R^{1} / R^{2} / R^{4}=P h / O M e / C O P h\right)$<smiles>Nc1ccccc1C(O)(C#Cc1ccccc1)c1ccccc1</smiles>

312<smiles>CC(C)(C)OC(=O)C=C=CCc1ccccc1</smiles>

314

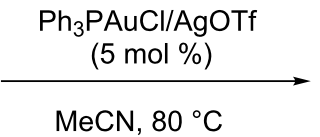

$\mathrm{MeCN}, 80^{\circ} \mathrm{C}$<smiles>[R]c1cc2cc([R])c3c(c2cc1[R])C([R])(O)c1ccccc1-3</smiles>

305 (73\%)

307 (50\%)

309 (55\%)

311 (52\%)

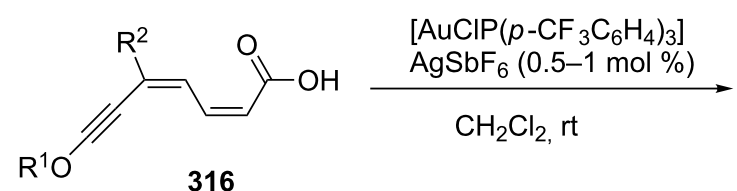<smiles>[R]OC(=O)c1c([R])cccc1O</smiles>

317

$\mathrm{R}^{1}=\mathrm{Me}, \mathrm{Et}$

$\mathrm{R}^{2}=\mathrm{Ar}$, alkyl, TMS, alkynyl, alkenyl<smiles>CC(=O)c1c(O)cccc1-c1ccccc1</smiles>

318

Yield 70\%<smiles>CC(=O)c1c(O)cccc1-c1cccc2ccccc12</smiles>

319

Yield 71\%<smiles>CC(=O)c1c(O)cccc1/C=C/c1ccccc1</smiles>

320

Yield 78\%<smiles>COC(=O)c1c(O)cccc1Br</smiles>

321

Yield 66\% 
Liu et al. has developed two highly stereoselective cationic gold(I)-catalyzed tandem cyclization reactions of alkynylindoles 322 [160]. The reaction proceeds with remarkable retention of chirality and allows the efficient enantioselective synthesis of polycyclic indolines $\mathbf{3 2 7}$ from the corresponding enantiomerically enriched alkynylindole 326 (Scheme 55).
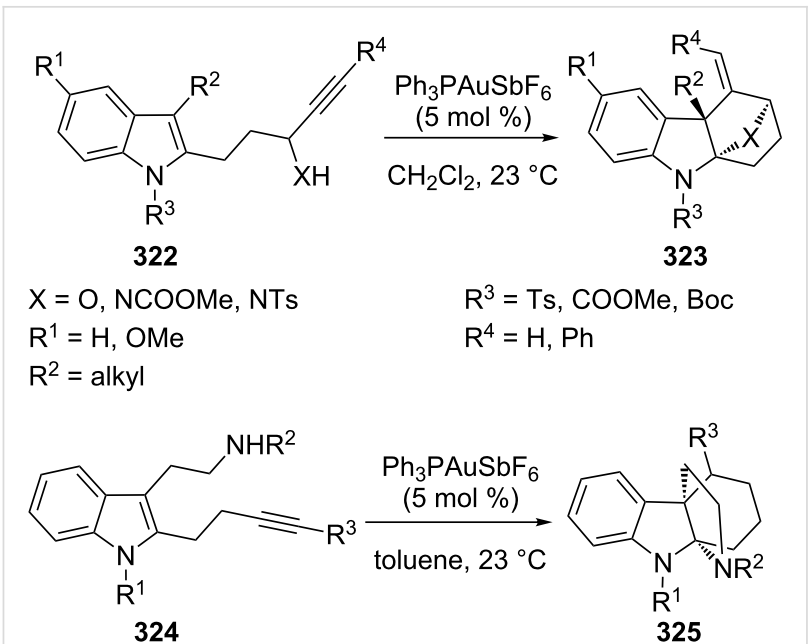

$\mathrm{R}^{1}=\mathrm{H}$, Boc, Me

$\mathrm{R}^{3}=\mathrm{H}, \mathrm{Ph}$

$\mathrm{R}^{2}=\mathrm{Ac}, \mathrm{Boc}, \mathrm{Ts}$

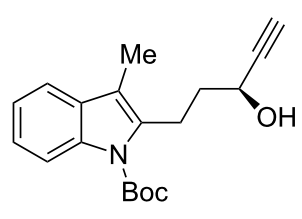

326

$81 \%$ ee

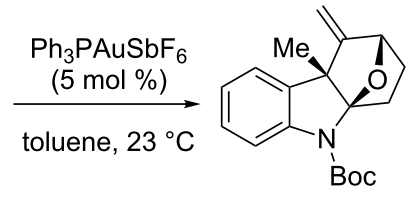

327

$81 \%$ ee
Scheme 55: Gold(I)-catalyzed tandem cyclization approach to tetracyclic indolines.

\subsection{Sequential intra-and intermolecular reactions}

In an attempt to devise an efficient synthesis of potential bioactive fused heterocyles, our group developed a highly efficient, $\left[\mathrm{Au}\left\{\mathrm{P}(t \text {-Bu })_{2}(o\right.\right.$-biphenyl $\left.\left.)\right\}\left\{\mathrm{CH}_{3} \mathrm{CN}\right\}\right] \mathrm{SbF}_{6}$-catalyzed cascade cycloisomerization to produce pyrrolo/pyrido[2,1$b]$ benzo[d][1,3]oxazin-1-ones 330 [161], pyrrolo/pyrido[2,1$a][1,3]$ benzoxazinones 332 [162], benzo[e]indolo[1,2-a]pyrrolo[2,1-c][1,4]diazepine-3,9-diones 335 [163], and fused quinoxalinones 337 [164]. These cascades are proposed to occur from an initial enol lactone intermediate via an intramolecular cycloaddition [165]. A subsequent intermolecular hydroamination of the intermediate, followed by a cyclization, leads to the observed products. Our group also investigated the construction of highly functionalized pyrrolo[1,2- $a]$ quinolin$1(2 H)$-ones 340 via a $\mathrm{AuBr}_{3} / \mathrm{AgSbF}_{6}$-catalyzed cascade transformation sequence (Scheme 56). The strategy affords a straightforward and efficient construction of tricyclic lactam molecular architectures in which several carbon-carbon and carbon-nitrogen bonds are formed in a one-pot reaction from simple starting materials [166].

The catalytic conversion of $\mathrm{C}\left(\mathrm{sp}^{3}\right)-\mathrm{Au}$ bonds into $\mathrm{C}\left(\mathrm{sp}^{3}\right)-\mathrm{C}\left(\mathrm{sp}^{2}\right)$ bonds is an ongoing challenge. In 2010, Zhang's group reported the first example in an intermolecular oxidative cross-coupling manner [167]. In their pioneering work, carboamination, carboalkoxylation and carbolactonization of terminal alkenes 341 was achieved via oxidative gold catalysis and provided expedient access to various substituted $N$ - or $O$-heterocycles (344-351) (Scheme 57). Deuterium labeling experiments were carried out to unveil the reaction mechanism. The results established the anti nature of the alkene functionalization and the indispensable role of $\mathrm{Au}(\mathrm{I}) / \mathrm{Au}$ (III) catalysis. Toste's group and Russell's group subsequently reported the aminoarylation and oxyarylation of alkenes ( $\mathbf{3 5 2}$ and $\mathbf{3 5 5}$ ) following a similar protocol $[168,169]$. In the gold-catalyzed intramolecular aminoarylation of alkenes, ligand and halide effects played a dramatic role for the addition to alkenes. The experimental studies suggest that the $\mathrm{C}-\mathrm{C}$ bond-forming reaction occurs through a bimolecular reductive elimination. Furthermore, a gold-catalyzed three-component coupling was also developed for the oxidative oxyarylation of alkenes $\mathbf{3 5 8}$ via a similar strategy [170].

From the discovery and development of metal-carbenoids in cycloadditions with alkenes, as well as the internal redox reactions on alkynes, a further extensive investigation was focused on the new redox/cycloaddition cascades on alkynes to obtain azacyclic compounds 363 [171]. The central cores of the products were constructed through a formal $[2+2+1]$ cycloaddition that involved $\alpha$-carbonyl-carbenoids, nitroso species and external alkenes (Scheme 58).

A gold(I)-catalyzed cascade cyclization/oxidative crosscoupling process has been devised to prepare $\beta$-alkynyl- $\gamma$ butenolides 366 directly from allenoates 364 and various terminal alkynes [172]. The González group developed an intermolecular reaction of internal alkynes and imines, in which the propargyl tosylates 367 react with $N$-tosylaldimines 368 to afford cyclopent-2-enimines 369 [173]. The final product was achieved through a 1,2-migration of the tosylate followed by the interaction with the imine and a Nazarov-like cyclization. Barluenga et al. reported a gold-catalyzed cascade reaction involving an unusual intramolecular redox process in which 5-heteroaryl-substituted ketone derivatives $\mathbf{3 7 2}$ were obtained from secondary 5-hexyn-1-ols 370 (Scheme 59) [174]. The first step is supposed to be an intramolecular addition of the hydroxy group to the internal carbon of the triple bond, which is similar to the mechanism mentioned above $[161,163]$. 
<smiles>[R]C(O)c1c[R1]ccc1N</smiles>

328<smiles>[R]C(=NC#C)C(=O)O</smiles>

329<smiles>[R]C1C(=O)N2C(C)(C)OC([R])C2(CC)C1[R]</smiles>

330

$n=1,2$

$\mathrm{R}^{1}=\mathrm{H}$, halogen, $\mathrm{Ar} ; \mathrm{R}^{2}=\mathrm{H}, \mathrm{Me} ; \mathrm{R}^{3}=\mathrm{H}$, alkyl<smiles>[R]C(=O)c1c[R1]ccc1N</smiles>

331<smiles>[R]C(C#C)C(=O)O</smiles>

329 $\underset{\text { one-pot }}{\stackrel{\mathrm{Au}(\mathrm{I}) \text { catalyst }}{\longrightarrow}}$

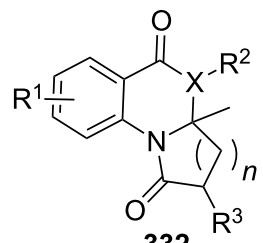

$n=1,2$

$\mathrm{X}=\mathrm{O}, \mathrm{N}$

$\mathrm{R}^{1}=\mathrm{H}, \mathrm{Me}, \mathrm{Cl}, \mathrm{OMe} ; \mathrm{R}^{2}=\mathrm{H}$, alkyl; $\mathrm{R}^{3}=\mathrm{H}$, alkyl<smiles>[R]c1ccc(C(=O)n2ccc3cc([R])ccc32)c(N)c1</smiles>

333<smiles>[R]C(C(=O)O)[Y]([Y])([H])C#C</smiles>

334

$\mathrm{AgSbF}_{6}(20 \mathrm{~mol} \%)$ $\mathrm{Au}(\mathrm{l})$ catalyst $(5 \mathrm{~mol} \%)$ toluene, $120^{\circ} \mathrm{C}$ $12 \mathrm{~h}$ or $18 \mathrm{~h}$

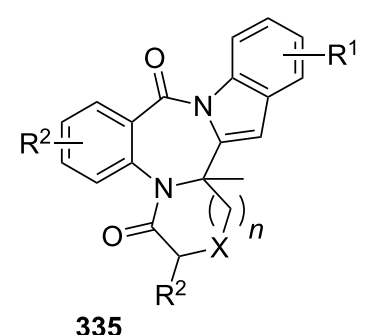

$n=0,1$

$\mathrm{X}=\mathrm{CH}_{2}, \mathrm{O}$

$\mathrm{R}^{1}=\mathrm{H}, \mathrm{Me}, \mathrm{F}, \mathrm{Cl}, \mathrm{CN} ; \mathrm{R}^{2}=\mathrm{H}, \mathrm{Me}, \mathrm{F}, \mathrm{Cl} ; \mathrm{R}^{3}=\mathrm{H}$, alkyl<smiles>[R]c1cccc(N)c1-n1ccc([R])c1CCC</smiles>

336<smiles>[R]C(C#C)C(=O)OC1CC1C#C</smiles>

329

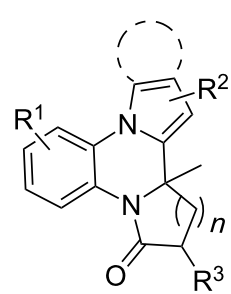

337

$n=1,2$

$\mathrm{R}^{1}=\mathrm{H}, \mathrm{Me}, \mathrm{F}, \mathrm{OMe}, \mathrm{CN}, \mathrm{CF}_{3} ; \mathrm{R}^{2}=\mathrm{H}, \mathrm{Me}, \mathrm{F}, \mathrm{OMe} ; \mathrm{R}^{3}=\mathrm{H}$, alkyl

$\mathrm{Au}(\mathrm{I})$ catalyst $=\left[\mathrm{Au}\left\{\mathrm{P}(t-\mathrm{Bu})_{2}(o-\right.\right.$ biphenyl $\left.\left.)\right\}\left\{\mathrm{CH}_{3} \mathrm{CN}\right\}\right] \mathrm{SbF}_{6}$

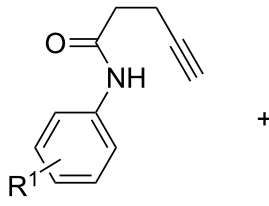

338

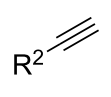

339

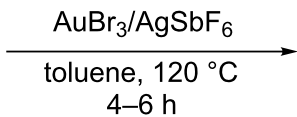

4-6 h<smiles>[R][R7]1ccc2c(c1)C([R])=CC1(C)CCC(=O)N21</smiles>

340

$\mathrm{R}^{1}=\mathrm{H}, \mathrm{Br}, \mathrm{F}, \mathrm{OPh}$, COOEt; $\mathrm{R}^{2}=\mathrm{H}, \mathrm{Cl}, \mathrm{F}, \mathrm{Ph}$ 


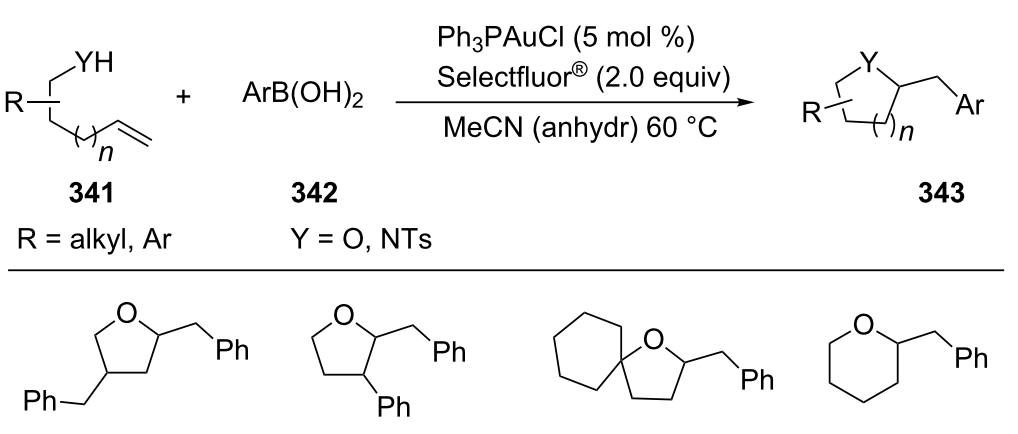

$\mathbf{3 4 4}, 71 \%(2 \mathrm{~h}) \quad \mathbf{3 4 5}, 61 \%(2 \mathrm{~h}) \quad \mathbf{3 4 6}, 56 \%(8 \mathrm{~h}) \quad \mathbf{3 4 7}, 35 \%(2 \mathrm{~h})$

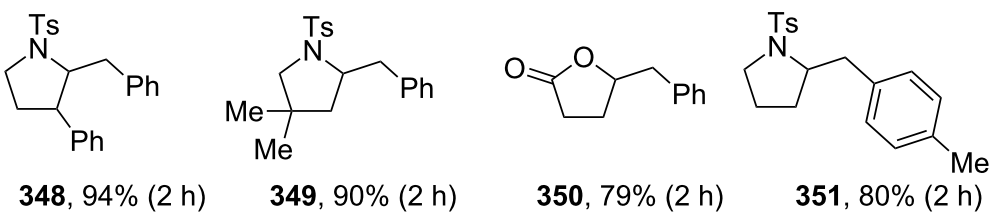

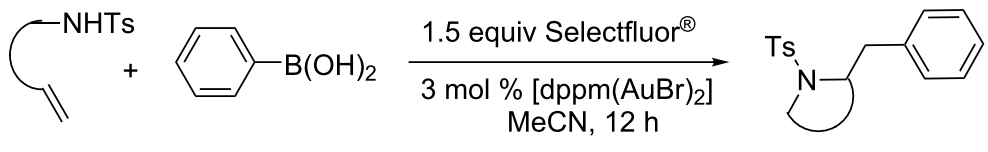

$352 \quad 353$

354<smiles>[R]c1ccccc1[SiH](C)C</smiles>

$355 \quad 356$

$\mathrm{R}=\mathrm{H}, \mathrm{Me}, \mathrm{F}, \mathrm{Br}, \mathrm{CO}_{2} \mathrm{Me}$

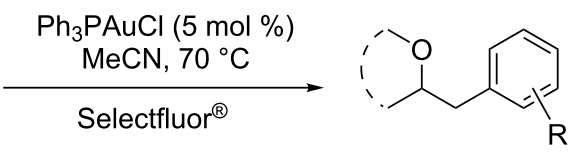

357

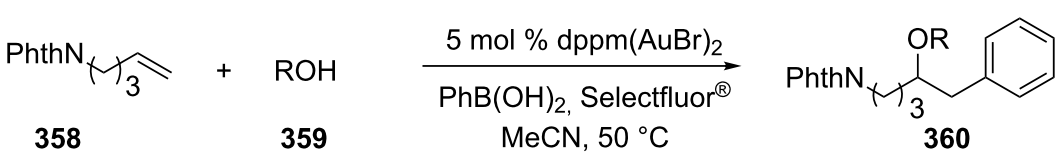

$\mathrm{R}=\mathrm{alkyl}, \mathrm{acyl}$

Scheme 57: Aminoarylation and oxyarylation of alkenes.

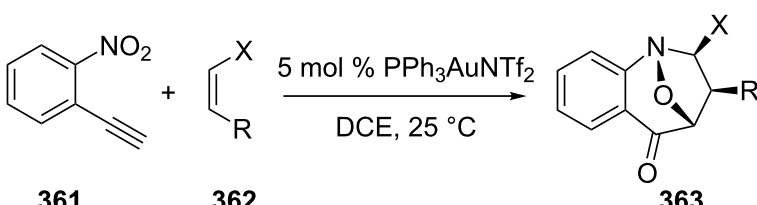

$\mathrm{R}=\mathrm{H}$, alkyl

$\mathrm{X}=$ alkoxy, alkyl sulfide, $\mathrm{Ar}$

Scheme 58: Cycloaddition of 2-ethynylnitrobenzene with various alkenes.

\section{Gold-catalyzed asymmetric addition reactions}

The chiral ligand used for the transition metal-catalyzed reactions are the main determinant of enantioselectivity. Although asymmetric catalysis using chiral organometal complexes and chiral organomolecules have shown many advantages and a range of catalytic asymmetric reactions have been well documented [175], gold-catalyzed asymmetric addition reactions do not feature often. More recently this situation has been changing with significant progress being made in this area. To date, a broad range of chiral catalysts have been developed. Despite the large amount of chiral ligands used, only a few provided good to high enantioselectivities. The best ee values have been obtained with thiourea-cinchonine [176], chiral carbene [177], BINAP [178-180], and BIPHEP [181-190] analogs.

Monge et al. reported a direct asymmetric one-pot synthesis of optically active 2,3-dihydropyrroles from propargyl malononitriles 375 and $N$-Boc-protected imines 374 (Scheme 60) [176]. In the alkyne hydroamination (which is based on a bifunctional organocatalytic Mannich-type reaction, subsequent gold- 


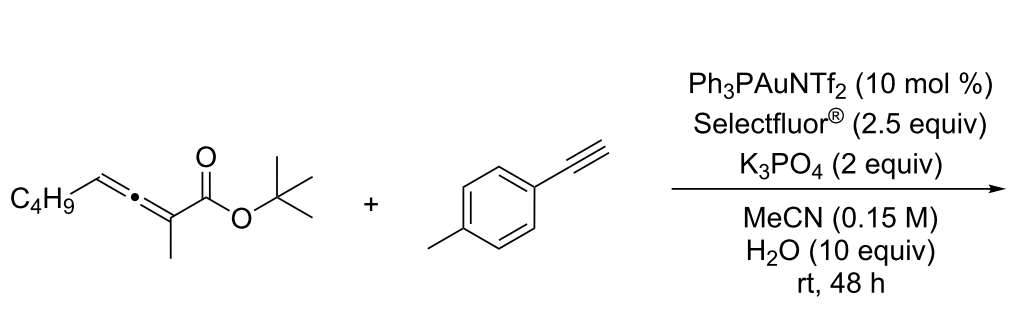

\section{C-O bond forming cyclization}

364

365

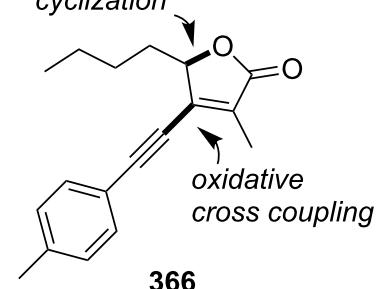<smiles></smiles>

367

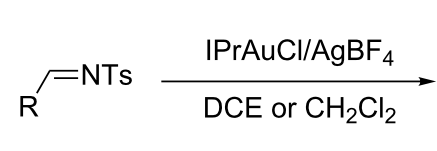

368<smiles>[R]C1=C(Br)C([R16])C(C)(C)C1C</smiles>

369

372<smiles>[R]C#CCCCC([R])O</smiles>

Scheme 59: Gold-catalyzed tandem reactions of allenoates and alkynes.

catalyzed alkyne hydroamination and isomerization) thioureabased hydrogen bonding organocatalyst 373 and $\mathrm{PPh}_{3} \mathrm{AuNTf}_{2}$ proved to be compatible upon protonation with $p-\mathrm{TsOH}$. Electron-poor aromatic imines can be employed to give the corresponding 2,3-dihydropyrroles 376 in good yields (74-80\%) and enantioselectivities $(68-72 \%$ ee). However, lower enantioselectivity may result from the more electron-rich substituent groups. For example, the heteroaromatic thiophene-based imine gave the desired products 379 in good yield (70\%), albeit in moderate enantioselectivity ( $58 \%$ ee).

In the study of enantioselective cyclization, for example, of 1,6enynes $\mathbf{3 8 1}$ for the synthesis of cyclopentane derivatives $\mathbf{3 8 2}$, Matsumoto and co-workers found chiral carbene- $\mathrm{AuCl}$ catalyst precursor $\mathbf{3 8 0}$ gave moderate enantioselectivity of up to $59 \%$ (Scheme 61) [177].

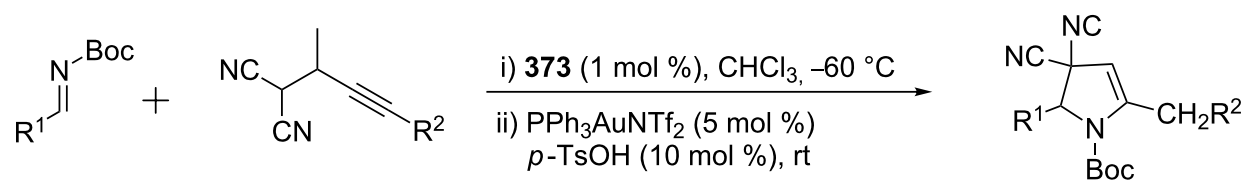

374

$\mathrm{R}^{1}=\mathrm{Ar}$

$\mathrm{R}^{2}=\mathrm{H}, \mathrm{Ph}$<smiles>C=CC1CN2CCC1C2[C@H](NC(=S)NC1CCCCCC1)c1ccnc2ccc(OC)cc12</smiles>

373<smiles>CC1=CC(C#N)(C#N)C(c2ccccc2)N1C(=O)OCc1ccccc1</smiles>

377

Yield 70\% ee $82 \%$<smiles>CC1=CC(C#N)(C#N)C(c2cccc3ccccc23)N1C(=O)OCc1ccccc1</smiles>

378

Yield 65\% ee $72 \%$<smiles>CC1=CC(C#N)(C#N)C(c2cccs2)N1C(=O)OC(C)(C)C</smiles>

379

Yield 70\%

ee $58 \%$

Scheme 60: Gold-catalyzed asymmetric synthesis of 2,3-dihydropyrroles. 


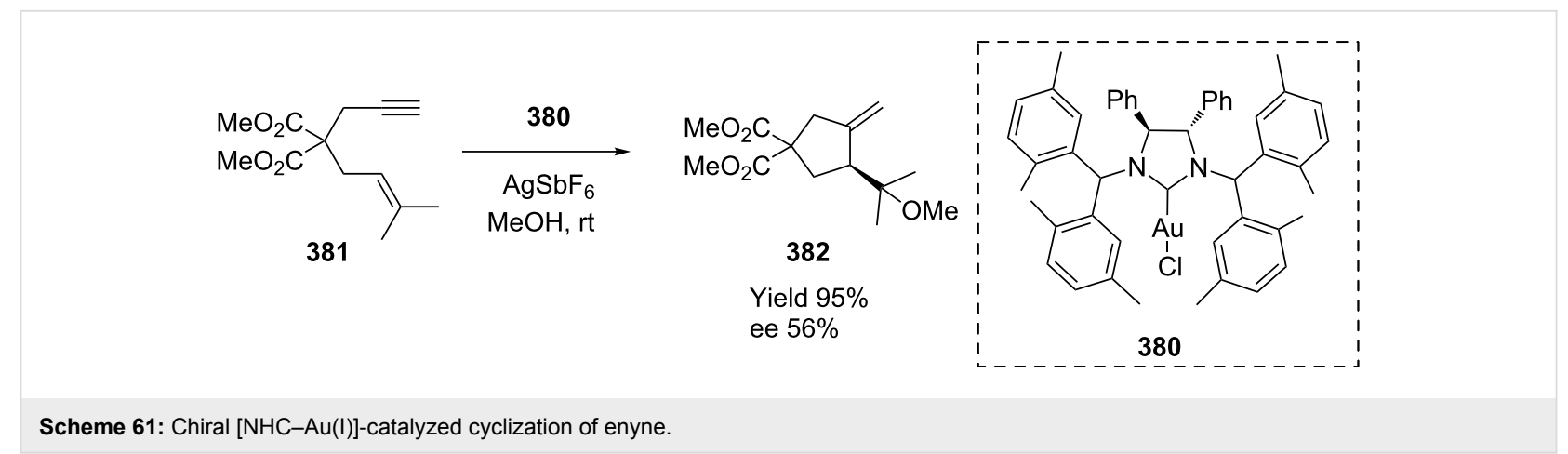

In the last 3 years, enantioselective gold-catalyzed reactions with BINAP and BIPHEP analogs have been far more documented compared to other ligands. In 2009, Toste's group reported the application of $\left.[(R) \text {-xylyl-binap-(AuOPNB })_{2}\right] \mathbf{3 8 3}$ in gold-catalyzed hydroaminations and hydroalkoxylations of allenes with hydroxylamines and hydrazines, which gave ee values of up to $99 \%$ [178]. Whereas chiral biarylphosphinegold(I) complexes are suitable catalysts for the enantioselective addition of nitrogen nucleophiles to allenes, the addition of oxygen nucleophiles requires the use of chiral anions $\mathbf{3 8 4}$ (Scheme 62).

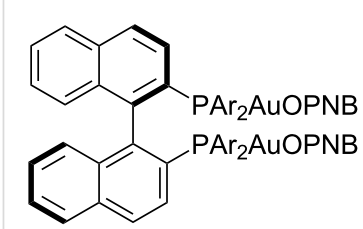

383

$\mathrm{Ar}=3,5-\mathrm{xylyl}$

$\left.[(R) \text {-xylyl-binap(AuOPNB })_{2}\right]$

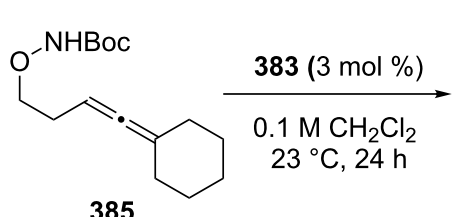

385

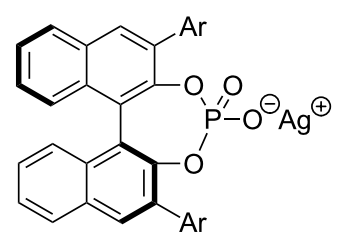

384

(S)-TriPAg (III) $\mathrm{Ar}=2,4,6$-triisopropylphenyl

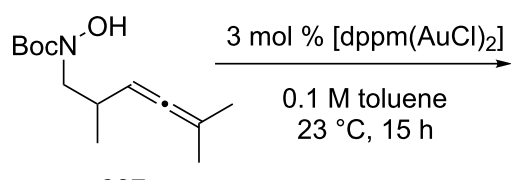

387
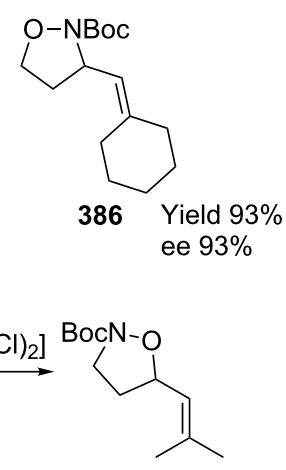

388 Yield 98\% ee $98 \%$

Scheme 62: Gold-catalyzed hydroaminations and hydroalkoxylations.

Gold(I)-catalyzed asymmetric cyclization of 1,3-dihydroxymethyl-2-alkynylbenzene chromium complexes $\mathbf{3 8 9}$ gave planar chiral isochromene-chromium complexes $\mathbf{3 9 0}$ with high enantioselectivity [179]. Enantioselectivities of the cyclized isochromene-chromium complexes are largely dependent on the combination of gold pre-catalysts and silver salts. The use of $\mathrm{AgSbF}_{6}$ resulted in excellent enantioselectivities, regardless of the nature of the gold pre-catalyst (Scheme 63).

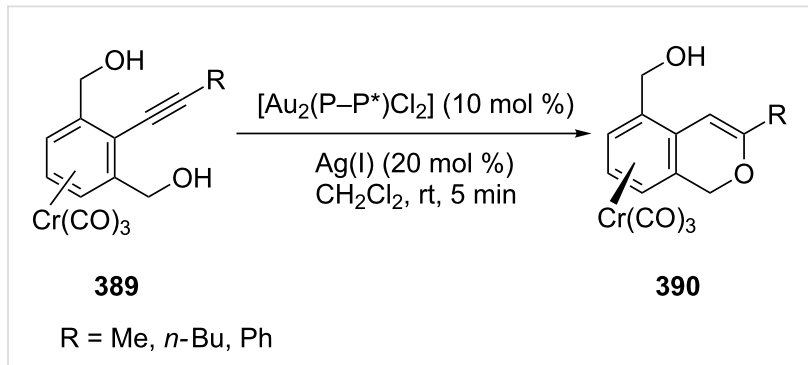

Scheme 63: Gold(I)-catalyzed asymmetric hydroalkoxylation of 1,3-dihydroxymethyl-2-alkynylbenzene chromium complexes.

Julolidine derivatives 396 were obtained via a highly enantioselective three-component (393-395) cascade reaction which involved an enantioselective $[4+2]$ cycloaddition reaction catalyzed by a chiral phosphoric acid and a subsequent catalytic intramolecular hydroamination by a gold(I) complex (Scheme 64) [180]. Further studies revealed that the Brønsted acid is both a chiral catalyst for the asymmetric cycloaddition and assists to facilitate the gold complex catalyzed hydroamination.

Muratore et al. have reported an interesting example of $\mathrm{C}-\mathrm{N}$ bond formation for the construction of chiral nitrogencontaining fused heterocycles 400 [191]. In this case, different alkynoic acids 397 were treated with $\mathrm{Ph}_{3} \mathrm{PAuCl} / \mathrm{AgOTf}$ and tryptamines $\mathbf{3 9 8}$ in the presence of $(R)-3,3^{\prime}-$ bis(triphenylsilyl)BPA 399. The multi-catalyst cascade products were isolated in good yields and with high ee values (Scheme 65).

BIPHEP is the most extensively used chiral atropisomeric biaryl diphosphine ligand in the gold catalytic enantioselective addi- 
<smiles>O=P1(O)Oc2c(Br)cc3ccccc3c2-c2c(Br)cc3ccccc3c2O1</smiles>

391, $\mathrm{Ar}=9$-anthracenyl<smiles>CC(C)(C)[PH](OC(=O)OP1(=O)Oc2c(Br)cc3ccccc3c2-c2c(c(Br)cc3ccccc23)O1)(c1ccccc1-c1ccccc1)C(C)(C)C</smiles>

392, $\mathrm{Ar}=$ 9-anthracenyl

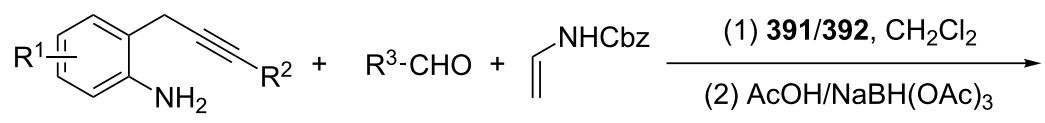

393
$\mathrm{R}^{1}=\mathrm{H}, 4-\mathrm{Cl}$
$\mathrm{R}^{2}=\mathrm{Ar}$
(2) $\mathrm{AcOH} / \mathrm{NaBH}(\mathrm{OAc})_{3}$<smiles>[R]C1CCc2cc[R1]c3c2N1C([R])C[C@H]3C(=O)O</smiles>

396

up to $>99 \%$ ee<smiles>[R]C#C[O]</smiles>

397<smiles>NCCc1c[nH]c2ccccc12</smiles>

398

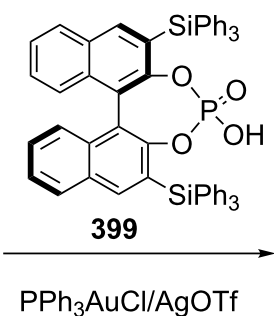

$\mathrm{PPh}_{3} \mathrm{AuCl} / \mathrm{AgOTf}$

Scheme 65: Gold-catalyzed the synthesis of chiral fused heterocycles.

tion. Although the gold catalysis has been well developed, the use of non-activated olefinic $\mathrm{C}-\mathrm{C}$ double bonds is still largely unexplored due to the intrinsic inertness of $\mathrm{C}=\mathrm{C}$ (with respect to allenes and alkynes) in taking part in nucleophilic addition reactions assisted by $\pi$-electrophilic activation [183]. The first example of a direct catalytic enantioselective Friedel-Crafts allylic alkylation reaction with alcohols was reported by Bandini's group [182]. In terms of stereo-induction, 3,5- $(t$ $\mathrm{Bu})_{2}$-4-MeO-MeOBIPHEP 401 (Scheme 66) gave the best results. Their method exploits the unprecedented capability of chiral gold(I) catalysts to activate selectively prochiral $\pi$-activated alcohols $\mathbf{4 0 2}$ toward aromatic functionalization in a highly enantioselective manner. On the basis of the above results, the same group extended the substrate scope of the 3,5$(t-\mathrm{Bu})_{2}-4-\mathrm{MeO}-\mathrm{MeOBIPHEP}-\mathrm{Au}-\mathrm{catalyzed}$ Friedel-Crafts- type alkylation to indolyl alcohols $\mathbf{4 0 4}$ bearing an unsaturated side chain at the $\mathrm{C} 2$ position of the indole [183]. 1,6-Enyne derivatives and their analogs are the most frequently used substrates for gold-catalyzed cycloisomerization. Chao et al. discovered that the combination of atropisomeric electron-rich and hindered chiral ligand 3,5-( $t$-Bu $)_{2}-4-\mathrm{MeO}-\mathrm{MeOBIPHEP}$ 401 with $\mathrm{Au}(\mathrm{I})$ and silver salts promoted the enantioselective hydroarylation/cyclization reaction of 1,6-enynes 406 under mild conditions [181]. Treatment of enynes with catalytic amount of 3,5-( $t$-Bu $)_{2}-4-\mathrm{MeO}-\mathrm{MeOBIPHEP}(\mathrm{AuCl})_{2}$ and AgOTf in $\mathrm{Et}_{2} \mathrm{O}$ at room temperature for 15-20 hours led to the desired arylated products with ee values up to $98 \%$. A similar strategy was also applied by the same group in the asymmetric $\mathrm{Au}(\mathrm{I})$-catalyzed synthesis of bicyclo[4.1.0]heptene derivatives 410 via a cycloisomerization process of 1,6-enynes 409 [184]. 


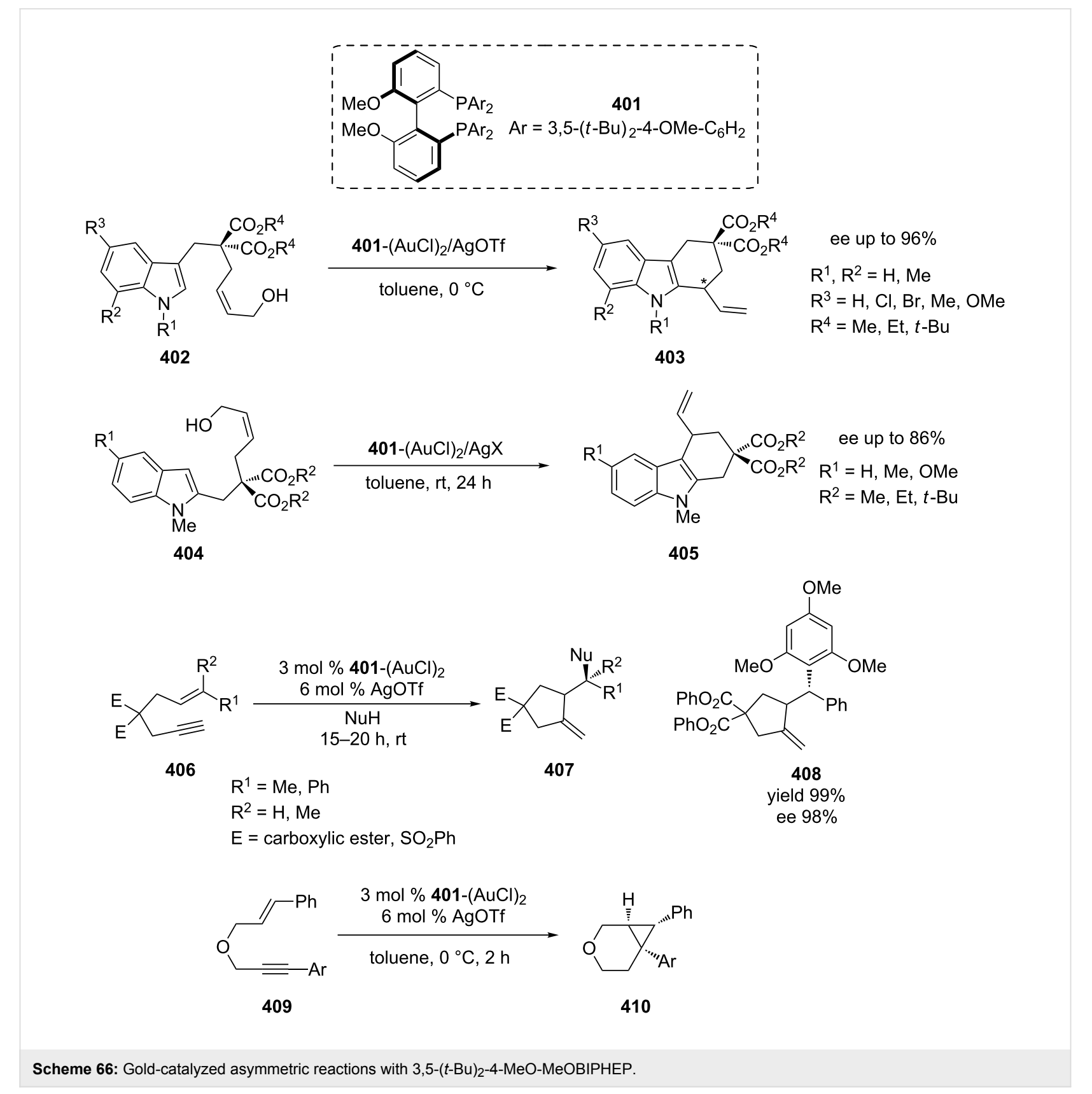

Employing the atropisomeric electron-rich ligand 3,5-xylylMeOBIPHEP 411 (Scheme 67), Sanz's group has developed an asymmetric gold-catalyzed cycloisomerization or alkoxycyclization of $o$-alkynylstyrenes $\mathbf{4 1 2}$ to prepare enantiomerically enriched functionalized $1 H$-indene derivatives $\mathbf{4 1 3}$ (including 414-417) with high ee values (up to 92\%) [190].

Due to the strength of $\mathrm{sp}^{3} \mathrm{C}-\mathrm{H}$ bonds and because it can be difficult for the metal to reach sterically hindered $\mathrm{C}-\mathrm{H}$ bonds, direct functionalization of $\mathrm{sp}^{3} \mathrm{C}-\mathrm{H}$ bonds remained a challenge for a long time. Recently, however, Zhang's group have presented the first example of an enantioselective redox-neutral domino reaction catalyzed by gold(I) that results in the direct functionalization of unreactive $\mathrm{sp}^{3} \mathrm{C}-\mathrm{H}$ bonds. Furan-fused azepine derivatives 419 (including 420-422) have been obtained from enyne $\mathbf{4 1 8}$ with high enantioselectivities (Scheme 68) [185].

Toste's group developed the first example of a highly enantioselective polyene $(\mathbf{4 2 3}, \mathbf{4 2 5}, \mathbf{4 2 7}, \mathbf{4 2 9})$ cyclization reaction in which transition metal-promoted alkyne activation serves as the cyclization initiating event [186]. The reactions of the enyne with the monocationic gold(I) complexes and $\mathrm{AgSbF}_{6}$ were carried out in the presence of sterically encumbered phosphines. 


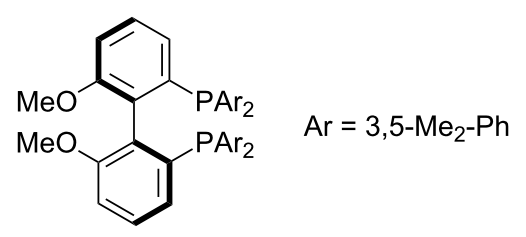

411<smiles>[R]C#Cc1cc([R])c([R])cc1C=C([R])C[R]</smiles>

412

411-(AuCl) 2 (5 mol \%) $\mathrm{Ag}(\mathrm{I})(10 \mathrm{~mol} \%)$

$\mathrm{R}^{6} \mathrm{OH}, \mathrm{CH}_{2} \mathrm{Cl}_{2},-30^{\circ} \mathrm{C}$<smiles>[R]CC([R7])([R])C1C([R])=Cc2cc([R])c([R])cc21</smiles>

413

$\mathrm{R}^{1}=\mathrm{H}$, alkoxy $\mathrm{R}^{2}=\mathrm{H}, \mathrm{F}, \mathrm{Br}$, alkoxy $\mathrm{R}^{3}=\mathrm{H}$, alkyl

$\mathrm{R}^{4}=\mathrm{alkyl}$

$\mathrm{R}^{5}=\mathrm{Ph}, 3-\mathrm{Th}, n-\mathrm{Bu}$

$\mathrm{R}^{6}=\mathrm{H}$, alkyl, allyl<smiles>COC(C)(C)[C@H]1C(c2ccccc2)=Cc2ccccc21</smiles>

414

ee $88 \%$<smiles>CCC(C)(C)[C@H]1C(c2ccccc2)=Cc2ccccc21</smiles>

415

ee $92 \%$<smiles>CC(C)(O)[C@H]1C(c2ccccc2)=Cc2ccc(F)cc21</smiles>

416

ee $86 \%$<smiles>CC(C)(O)[C@H]1C(c2ccccc2)=Cc2cc3c(cc21)OCO3</smiles>

417

ee $88 \%$

Scheme 67: Gold-catalyzed cyclization of o-(alkynyl) styrenes.<smiles>[R]C#C/C(=C/c1cc[R8]([R])cc1N([R])C[R])C([R])=O</smiles>

418

401-(AuCl) $)_{2} / \mathrm{Ag}(\mathrm{I})(1: 1)(5 \mathrm{~mol} \%)$ $\mathrm{CH}_{3} \mathrm{CN}$, rt<smiles>[R][R]c1oc([R])c2c1Cc1cc[R]([R])cc1N([R])C2[R]</smiles>

419

$$
\mathrm{R}^{1}=\mathrm{Me}, \mathrm{Ph}
$$

$\mathrm{R}^{2}=$ aryl, alkyl

$\mathrm{R}^{3}, \mathrm{R}^{4}=$ alkyl

$\mathrm{R}^{5}=\mathrm{H}, \mathrm{Br}$<smiles>Cc1oc(-c2ccccc2)c2c1Cc1ccc(Br)cc1N1CCOC[C@H]21</smiles>

420<smiles>Cc1oc(C)c2c1Cc1ccccc1N1CCOC[C@H]21</smiles>

421<smiles>Cc1oc(C)c2c1Cc1ccccc1N1CCOC[C@H]21</smiles>

422

$94 \%$ yield, $97 \%$ ee, $5.0 \mathrm{~h}$

$84 \%$ yield, $94 \%$ ee, $7.0 \mathrm{~h}$

$57 \%$ yield, $79 \%$ ee, $3.5 \mathrm{~h}$

The use of 3,5-(t-Bu) $)_{2}-4-\mathrm{MeO}-\mathrm{MeOBIPHEP} 401$ resulted in the formation of fused bicyclic compounds $(424,426,428,430)$ with good ee values (Scheme 69).
The 3,5-( $t$-Bu $)_{2}-4-\mathrm{MeO}-\mathrm{MeOBIPHEP}-\mathrm{Au}$ complex was also employed in the carboalkoxylation reaction of propargyl esters $\mathbf{4 3 1}$ to afford benzopyrans $\mathbf{4 3 2}$ containing quaternary stereocen- 
<smiles>C#CCC(COCC)(C/C(C)=C/CCC[NH3+])C(OCC)OCC</smiles>

423<smiles>C#CCC(COCC)(C/C(C)=C/Cc1ccccc1O)C(=O)OCC</smiles><smiles>C#CCC(C/C(C)=C/Cc1cc(OC)ccc1OC)(C(=O)OCC)C(=O)OCC</smiles>

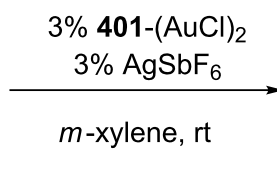<smiles>C=C1CC(COCC)(C(=O)OCC)C[C@]2(C)[C@H]1CCCN2[13CH3]</smiles>

424

$57 \%$ yield, $92 \%$ ee

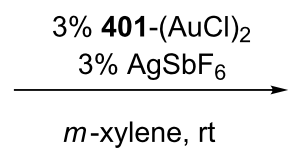<smiles>C=C1CC(C)(COCC)C[C@]2(C)Oc3ccccc3C[C@H]12</smiles>

426

$96 \%$ yield, $93 \%$ ee<smiles>C=C1CC(C)(C(=O)OCC)C[C@H]2c3c(cc(OC)cc3OC)CC[C@H]12</smiles>

$98 \%$ yield, $94 \%$ ee<smiles>C#CCC(F)(F)C/C(C)=C/CC/C(C)=C/CCCc1ccccc1O</smiles>

429

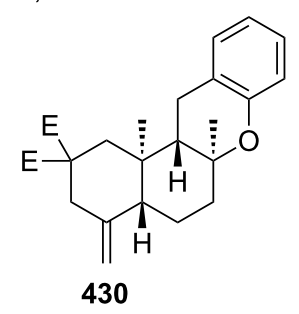

$50 \%$ yield, $88 \%$ ee

Scheme 69: Gold(I)-catalyzed enantioselective polyene cyclization reaction.

ters with excellent enantioselectivity (Scheme 70) [187]. Kleinbeck and Toste developed a gold(I)-catalyzed enantioselective ring expansion of allenylcyclopropanols 436 with the chiral ligand 3,5-xylyl-MeOBIPHEP 411 to obtain cyclobutanones 437 (including 438-441) (Scheme 71) [188]. Notably, the amount of catalyst could be reduced without significant loss of enantioselectivity or yield.

\section{Conclusion}

In this account, we have presented a summary of the recent gold catalysis which involves the addition of $\mathrm{X}-\mathrm{H}(\mathrm{X}=\mathrm{O}, \mathrm{N}, \mathrm{C})$ bonds to $\mathrm{C}-\mathrm{C}$ multiple bonds, tandem reactions, and asymmetric additions. The variety of reactions reflects that gold catalysis has become a very innovative synthetic tool in modern organic chemistry. What is particularly worth mentioning is that the design or choice of chiral ligands together with gold catalysts is the key to attaining high asymmetric induction. Up to now, only a small proportion of the chiral ligands have been

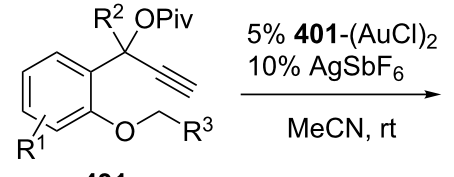

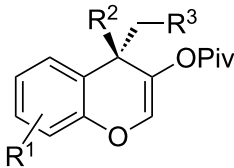

431

432

$\mathrm{R}^{1}=\mathrm{H}, 4-\mathrm{Cl}$, 4-Br, 4-t-Bu, 4- $\mathrm{Ph}, 4-\mathrm{OPh}, 5-t-\mathrm{Bu}$

$\mathrm{R}^{2}=$ alkyl, allyl

$\mathrm{R}^{3}=$ allyl<smiles>C[C@]1(C/C=C/c2ccccc2)C(O[Na])=COc2ccccc21</smiles>

433

ee $97 \%$<smiles>C=CC[C@@]1(C/C=C/c2ccccc2)C(O[Na])=COc2ccccc21</smiles>

434

ee $99 \%$<smiles>CCOC1=COc2ccccc2[C@]1(C)CC=C(C)C</smiles>

435

ee $97 \%$
Scheme 70: Gold(I)-catalyzed enantioselective synthesis of benzopyrans. 


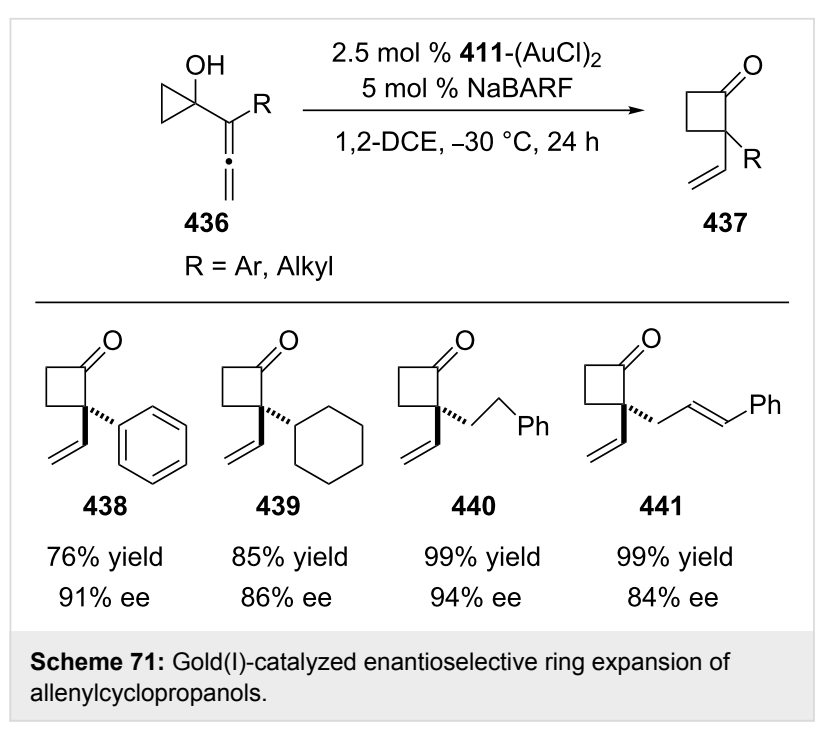

successfully introduced to gold-catalyzed reactions. Consequently, the development of new and efficient chiral ligands or chiral gold complexes is still a major challenge for the future.

\section{Acknowledgements}

We gratefully acknowledge financial support from the National Natural Science Foundation of China (Grants 21021063 , 20872153 and 81025017).

\section{References}

1. Hashmi, A. S. K.; Bührle, M. Aldrichimica Acta 2010, 43, 27-33.

2. Shapiro, N. D.; Toste, F. D. Synlett 2010, 675-691. doi:10.1055/s-0029-1219369

3. Patil, N. T.; Yamamoto, Y. ARKIVOC 2007, (v), 6-19.

4. Hashmi, A. S. K. Pure Appl. Chem. 2010, 82, 657-668. doi:10.1351/Pac-Con-09-10-17

5. Bandini, M. Chem. Soc. Rev. 2011, 40, 1358-1367. doi:10.1039/C0cs00041h

6. Arcadi, A. Chem. Rev. 2008, 108, 3266-3325. doi:10.1021/Cr068435d

7. Shen, H. C. Tetrahedron 2008, 64, 3885-3903. doi:10.1016/j.tet.2008.01.081

8. Shen, H. C. Tetrahedron 2008, 64, 7847-7870. doi:10.1016/j.tet.2008.05.082

9. Fürstner, A.; Davies, P. W. Angew. Chem., Int. Ed. 2007, 46, 3410-3449. doi:10.1002/anie.200604335

10. Hashmi, A. S. K.; Hutchings, G. J. Angew. Chem., Int. Ed. 2006, 45, 7896-7936. doi:10.1002/anie.200602454

11. Muzart, J. Tetrahedron 2008, 64, 5815-5849. doi:10.1016/j.tet.2008.04.018

12. Jiménez-Núñez, E.; Echavarren, A. M. Chem. Rev. 2008, 108, 3326-3350. doi:10.1021/Cr0684319

13. Hashmi, A. S. K. Chem. Rev. 2007, 107, 3180-3211. doi:10.1021/Cr000436x

14. Li, Z.; Brouwer, C.; He, C. Chem. Rev. 2008, 108, 3239-3265. doi:10.1021/Cr068434l

15. Skouta, R.; Li, C.-J. Tetrahedron 2008, 64, 4917-4938. doi:10.1016/j.tet.2008.03.083
16. Jiménez-Núñez, E.; Echavarren, A. M. Chem. Commun. 2007, 333-346. doi:10.1039/B612008c

17. Corma, A.; Leyva-Pérez, A.; Sabater, M. J. Chem. Rev. 2011, 111, 1657-1712. doi:10.1021/cr100414u

18. Eom, D.; Kang, D.; Lee, P. H. J. Org. Chem. 2010, 75, 7447-7450. doi:10.1021/Jo101474s

19. Balamurugan, R.; Koppolu, S. R. Tetrahedron 2009, 65, 8139-8142. doi:10.1016/j.tet.2009.07.087

20. Du, X. W.; Song, F. J.; Lu, Y. H.; Chen, H. Y.; Liu, Y. H. Tetrahedron 2009, 65, 1839-1845. doi:10.1016/j.tet.2008.11.109

21. Kim, S.; Kang, D.; Shin, S.; Lee, P. H. Tetrahedron Lett. 2010, 51, 1899-1901. doi:10.1016/j.tetlet.2010.02.026

22. Aponick, A.; Li, C.-Y.; Malinge, J.; Marques, E. F. Org. Lett. 2009, 11, 4624-4627. doi:10.1021/OI901901m

23. Aponick, A.; Biannic, B. Synthesis 2008, 3356-3359. doi:10.1055/s-0028-1083160

24. Bandini, M.; Monari, M.; Romaniello, A.; Tragni, M. Chem.-Eur. J. 2010, 16, 14272-14277. doi:10.1002/chem.201002606

25. Aksin, Ö.; Krause, N. Adv. Synth. Catal. 2008, 350, 1106-1112. doi:10.1002/adsc. 200800050

26. Rüttinger, R.; Leutzow, J.; Wilsdorf, M.; Wilckens, K.; Czekelius, C. Org. Lett. 2011, 13, 224-227. doi:10.1021/OI102628x

27. Wilckens, K.; Uhlemann, M.; Czekelius, C. Chem.-Eur. J. 2009, 15, 13323-13326. doi:10.1002/chem.200901702

28. Liu, L.-P.; Hammond, G. B. Org. Lett. 2009, 11, 5090-5092. doi:10.1021/OI902215n

29. Aponick, A.; Li, C.-Y.; Palmes, J. A. Org. Lett. 2009, 11, 121-124. doi:10.1021/OI802491m

30. Zhang, Y.; Xue, J. J.; Xin, Z. J.; Xie, Z. X.; Li, Y. Synlett 2008, 940-944. doi:10.1055/s-2008-1042910

31. Bauer, J. T.; Hadfield, M. S.; Lee, A.-L. Chem. Commun. 2008, 6405-6407. doi:10.1039/B815891f

32. Hadfield, M. S.; Bauer, J. T.; Glen, P. E.; Lee, A. L. Org. Biomol. Chem. 2010, 8, 4090-4095. doi:10.1039/C0ob00085j

33. Corma, A.; Ruiz, V. R.; Leyva-Pérez, A.; Sabater, M. J. Adv. Synth. Catal. 2010, 352, 1701-1710. doi:10.1002/adsc.201000094

34. Schuler, M.; Silva, F.; Bobbio, C.; Tessier, A.; Gouverneur, V. Angew. Chem., Int. Ed. 2008, 47, 7927-7930. doi:10.1002/anie.200802162

35. Hirai, T.; Hamasaki, A.; Nakamura, A.; Tokunaga, M. Org. Lett. 2009, 11, 5510-5513. doi:10.1021/OI9023166

36. Cuenca, A. B.; Mancha, G.; Asensio, G.; Medio-Simon, M. Chem.-Eur. J. 2008, 14, 1518-1523. doi:10.1002/chem.200701134

37. Ye, L. W.; Cui, L.; Zhang, G. Z.; Zhang, L. M. J. Am. Chem. Soc. 2010, 132, 3258-3259. doi:10.1021/Ja100041e

38. Cordonnier, M.-C.; Blanc, A.; Pale, P. Org. Lett. 2008, 10, 1569-1572. doi:10.1021/OI800219k

39. Li, Y.; Tang, P. P.; Chen, Y. X.; Yu, B. J. Org. Chem. 2008, 73, 4323-4325. doi:10.1021/Jo8003875

40. Götze, S.; Fitzner, R.; Kunz, H. Synlett 2009, 3346-3348. doi:10.1055/s-0029-1218356

41. Sureshkumar, G.; Hotha, S. Chem. Commun. 2008, 4282-4284. doi:10.1039/B806707d

42. Li, Y.; Yang, X. Y.; Liu, Y. P.; Zhu, C. S.; Yang, Y.; Yu, B. Chem.-Eur. J. 2010, 16, 1871-1882. doi:10.1002/chem.200902548

43. Thadke, S. A.; Hotha, S. Tetrahedron Lett. 2010, 51, 5912-5914. doi:10.1016/j.tetlet.2010.09.004

44. Belting, V.; Krause, N. Org. Biomol. Chem. 2009, 7, 1221-1225. doi:10.1039/B819704k 
45. Belot, S.; Vogt, K. A.; Besnard, C.; Krause, N.; Alexakis, A. Angew. Chem., Int. Ed. 2009, 48, 8923-8926. doi:10.1002/anie.200903905

46. Liu, L. P.; Hammond, G. B. Org. Lett. 2010, 12, 4640-4643. doi:10.1021/ol101985d

47. Kotera, A.; Uenishi, J.; Uemura, M. J. Organomet. Chem. 2010, 695, 2180-2190. doi:10.1016/j.jorganchem.2010.06.005

48. Seraya, E.; Slack, E.; Ariafard, A.; Yates, B. F.; Hyland, C. J. T. Org. Lett. 2010, 12, 4768-4771. doi:10.1021/OI101862u

49. Wang, Y. H.; Zhu, L. L.; Zhang, Y. X.; Chen, Z. L. Chem. Commun. 2010, 46, 577-579. doi:10.1039/B913348h

50. Liu, L.-P.; Xu, B.; Mashuta, M. S.; Hammond, G. B. J. Am. Chem. Soc. 2008, 130, 17642-17643. doi:10.1021/Ja806685j

51. Shi, Y. L.; Roth, K. E.; Ramgren, S. D.; Blum, S. A. J. Am. Chem. Soc. 2009, 131, 18022-18023. doi:10.1021/Ja9068497

52. Pennell, M. N.; Unthank, M. G.; Turner, P.; Sheppard, T. D. J. Org. Chem. 2011, 76, 1479-1482. doi:10.1021/j0102263t

53. Buzas, A. K.; Istrate, F. M.; Gagosz, F. Tetrahedron 2009, 65, 1889-1901. doi:10.1016/j.tet.2008.11.108

54. Ye, L.; He, W.; Zhang, L. J. Am. Chem. Soc. 2010, 132, 8550-8551. doi:10.1021/ja1033952

55. Widenhoefer, R. A.; Han, X. Q. Eur. J. Org. Chem. 2006, 4555-4563. doi:10.1002/ejoc.200600399

56. Sun, H.; Su, F.-Z.; Ni, J.; Cao, Y.; He, H.-Y.; Fan, K. N. Angew. Chem., Int. Ed. 2009, 48, 4390-4393. doi:10.1002/anie.200900802

57. He, L.; Lou, X. B.; Ni, J.; Liu, Y. M.; Cao, Y.; He, H. Y.; Fan, K. N. Chem.-Eur. J. 2010, 16, 13965-13969. doi:10.1002/chem.201001848

58. Zeng, X. M.; Soleilhavoup, M.; Bertrand, G. Org. Lett. 2009, 11, 3166-3169. doi:10.1021/OI901418c

59. Hill, A. W.; Elsegood, M. R. J.; Kimber, M. C. J. Org. Chem. 2010, 75, 5406-5409. doi:10.1021/Jo101035n

60. Hesp, K. D.; Stradiotto, M. J. Am. Chem. Soc. 2010, 132, 18026-18029. doi:10.1021/Ja109192w

61. Mukherjee, P.; Widenhoefer, R. A. Org. Lett. 2011, 13, 1334-1337. doi:10.1021/ol103175w

62. Nakamura, I.; Okamoto, M.; Terada, M. Org. Lett. 2010, 12, 2453-2455. doi:10.1021/OI100581m

63. Benedetti, E.; Lemière, G.; Chapellet, L.-L.; Penoni, A.; Palmisano, G.; Malacria, M.; Goddard, J.-P.; Fensterbank, L. Org. Lett. 2010, 12, 4396-4399. doi:10.1021/Ol101889h

64. Ye, D. J.; Wang, J. F.; Zhang, X.; Zhou, Y.; Ding, X.; Feng, E. G.; Sun, H. F.; Liu, G. N.; Jiang, H. L.; Liu, H. Green Chem. 2009, 11, 1201-1208. doi:10.1039/B904044g

65. Li, H.; Widenhoefer, R. A. Org. Lett. 2009, 11, 2671-2674. doi:10.1021/OI900730w

66. Iglesias, A.; Muñiz, K. Chem.-Eur. J. 2009, 15, 10563-10569. doi:10.1002/chem.200901199

67. Mukherjee, P.; Widenhoefer, R. A. Org. Lett. 2010, 12, 1184-1187. doi:10.1021/OI902923e

68. Nakamura, I.; Yamagishi, U.; Song, D.; Konta, S.; Yamamoto, Y. Chem.-Asian J. 2008, 3, 285-295. doi:10.1002/asia.200700278

69. Surmont, R.; Verniest, G.; De Kimpe, N. Org. Lett. 2009, 11, 2920-2923. doi:10.1021/OI900953n

70. Gouault, N.; Le Roch, M.; Cornée, C.; David, M.; Uriac, P. J. Org. Chem. 2009, 74, 5614-5617. doi:10.1021/Jo900693a

71. Huang, J. F.; Huang, X.; Liu, B. Org. Biomol. Chem. 2010, 8, 2697-2699. doi:10.1039/C003734f

72. Bates, R. W.; Dewey, M. R. Org. Lett. 2009, 11, 3706-3708. doi:10.1021/OI901094h
73. Ye, S. Y.; Yu, Z.-X. Org. Lett. 2010, 12, 804-807. doi:10.1021/OI9028786

74. Shu, X.-Z.; Liu, X.-Y.; Xiao, H.-Q.; Ji, K.-G.; Guo, L.-N.; Liang, Y.-M. Adv. Synth. Catal. 2008, 350, 243-248. doi:10.1002/adsc.200700452

75. Saito, A.; Konishi, T.; Hanzawa, Y. Org. Lett. 2010, 12, 372-374. doi:10.1021/OI902716n

76. Shapiro, N. D.; Shi, Y.; Toste, F. D. J. Am. Chem. Soc. 2009, 131, 11654-11655. doi:10.1021/Ja903863b

77. Chen, D.-D.; Hou, X.-L.; Dai, L.-X. Tetrahedron Lett. 2009, 50, 6944-6946. doi:10.1016/j.tetlet.2009.05.091

78. Davies, P. W.; Martin, N. Org. Lett. 2009, 11, 2293-2296. doi:10.1021/OI900609f

79. Davies, P. W.; Martin, N. J. Organomet. Chem. 2011, 696, 159-164. doi:10.1016/j.jorganchem.2010.08.040

80. Du, X. W.; Xie, X.; Liu, Y. H. J. Org. Chem. 2010, 75, 510-513. doi:10.1021/Jo902357x

81. Kothandaraman, P.; Foo, S. J.; Chan, P. W. H. J. Org. Chem. 2009, 74, 5947-5952. doi:10.1021/Jo900917q

82. Zhang, L.; Ye, D. J.; Zhou, Y.; Liu, G. N.; Feng, E. G.; Jiang, H. L.; Liu, H. J. Org. Chem. 2010, 75, 3671-3677. doi:10.1021/Jo100378u

83. Ye, D.; Zhang, X.; Zhou, Y.; Zhang, D.; Zhang, L.; Wang, H.; Jiang, H.; Liu, H. Adv. Synth. Catal. 2009, 351, 2770-2778. doi:10.1002/adsc.200900505

84. Ibrahim, N.; Hashmi, A. S. K.; Rominger, F. Adv. Synth. Catal. 2011, 353, 461-468. doi:10.1002/adsc.201000779

85. Huo, Z. B.; Yamamoto, Y. Tetrahedron Lett. 2009, 50, 3651-3653. doi:10.1016/j.tetlet.2009.03.129

86. Zhang, G. Z.; Peng, Y.; Cui, L.; Zhang, L. M. Angew. Chem., Int. Ed. 2009, 48, 3112-3115. doi:10.1002/anie.200900585

87. Kimber, M. C. Org. Lett. 2010, 12, 1128-1131. doi:10.1021/OI1001494

88. Li, P. H.; Wang, L.; Wang, M.; You, F. Eur. J. Org. Chem. 2008, 5946-5951. doi:10.1002/ejoc.200800765

89. Xie, C. S.; Zhang, Y. H.; Yang, Y. Z. Chem. Commun. 2008, 4810-4812. doi:10.1039/B806821f

90. Tarselli, M. A.; Liu, A.; Gagne, M. R. Tetrahedron 2009, 65, 1785-1789. doi:10.1016/j.tet.2008.10.110

91. Brand, J. P.; Charpentier, J.; Waser, J. Angew. Chem., Int. Ed. 2009, 48, 9346-9349. doi:10.1002/anie.200905419

92. Kar, A.; Mangu, N.; Kaiser, H. M.; Beller, M.; Tse, M. K. Chem. Commun. 2008, 386-388. doi:10.1039/B714928j

93. Barluenga, J.; Tudela, E.; Vicente, R.; Ballesteros, A.; Tomás, M. Angew. Chem., Int. Ed. 2011, 50, 2107-2110. doi:10.1002/anie.201007795

94. Li, C. K.; Zeng, Y.; Zhang, H.; Feng, J. J.; Zhang, Y.; Wang, J. B. Angew. Chem., Int. Ed. 2010, 49, 6413-6417. doi:10.1002/anie.201002673

95. Li, C.-W.; Pati, K.; Lin, G.-Y.; Abu Sohel, S. M.; Hung, H.-H.; Liu, R.-S. Angew. Chem., Int. Ed. 2010, 49, 9891-9894. doi:10.1002/anie.201004647

96. Zou, Y.; Garayalde, D.; Wang, Q. R.; Nevado, C.; Goeke, A. Angew. Chem., Int. Ed. 2008, 47, 10110-10113. doi:10.1002/anie.200804202

97. Horino, Y.; Yamamoto, T.; Ueda, K.; Kuroda, S.; Toste, F. D. J. Am. Chem. Soc. 2009, 131, 2809-2811. doi:10.1021/Ja808780r

98. Patil, N. T.; Yamamoto, Y. Chem. Rev. 2008, 108, 3395-3442. doi:10.1021/Cr050041j

99. Chaudhuri, R.; Liao, H.-Y.; Liu, R.-S. Chem.-Eur. J. 2009, 15, 8895-8901. doi:10.1002/chem.200900580 
100.Benitez, D.; Tkatchouk, E.; Gonzalez, A. Z.; Goddard, W. A., III; Toste, F. D. Org. Lett. 2009, 11, 4798-4801. doi:10.1021/OI9018002 101.Mauleón, P.; Zeldin, R. M.; González, A. Z.; Toste, F. D. J. Am. Chem. Soc. 2009, 131, 6348-6349. doi:10.1021/Ja901649s 102.Alonso, I.; Trillo, B.; López, F.; Montserrat, S.; Ujaque, G.; Castedo, L.; Lledós, A.; Mascareñas, J. L. J. Am. Chem. Soc. 2009, 131, 13020-13030. doi:10.1021/Ja905415r

103.Cui, L.; Peng, Y.; Zhang, L. M. J. Am. Chem. Soc. 2009, 131, 8394-8395. doi:10.1021/Ja903531g

104.Teng, T.-M.; Liu, R.-S. J. Am. Chem. Soc. 2010, 132, 9298-9300. doi:10.1021/Ja1043837

105.Kusama, H.; Karibe, Y.; Onizawa, Y.; Iwasawa, N. Angew. Chem., Int. Ed. 2010, 49, 4269-4272. doi:10.1002/anie.201001061

106.Gao, H. Y.; Wu, X. X.; Zhang, J. L. Chem. Commun. 2010, 46, 8764-8766. doi:10.1039/C0cc02778b

107.Hsu, Y.-C.; Datta, S.; Ting, C.-M.; Liu, R.-S. Org. Lett. 2008, 10 521-524. doi:10.1021/OI7030334

108.Shapiro, N. D.; Toste, F. D. J. Am. Chem. Soc. 2008, 130 , 9244-9245. doi:10.1021/Ja803890t

109.Gung, B. W.; Craft, D. T.; Bailey, L. N.; Kirschbaum, K. Chem.-Eur. J. 2010, 16, 639-644. doi:10.1002/chem.200902185

110.Leseurre, L.; Chao, C.-M.; Seki, T.; Genin, E.; Toullec, P. Y.; Genêt, J.-P.; Michelet, V. Tetrahedron 2009, 65, 1911-1918. doi:10.1016/j.tet.2008.11.105

111.Lee, J. C. H.; Hall, D. G. Tetrahedron Lett. 2011, 52, 321-324. doi:10.1016/j.tetlet.2010.11.051

112.Li, G. J.; Liu, Y. H. J. Org. Chem. 2010, 75, 2903-2909. doi:10.1021/Jo100137j

113.Chen, Z. L.; Zhang, Y.-X.; Wang, Y.-H.; Zhu, L.-L.; Liu, H.; Li, X.-X.; Guo, L. Org. Lett. 2010, 12, 3468-3471. doi:10.1021/Ol1012923

114. Toullec, P. Y.; Blarre, T.; Michelet, V. Org. Lett. 2009, 11, 2888-2891. doi:10.1021/OI900864n

115. Escribano-Cuesta, A.; López-Carrillo, V.; Janssen, D.; Echavarren, A. M. Chem.-Eur. J. 2009, 15, 5646-5650. doi:10.1002/chem.200900668

116. Echavarren, A. M.; Jiménez-Núñez, E. Top. Catal. 2010, 53, 924-930. doi:10.1007/s11244-010-9524-6

117.Sperger, C.; Fiksdahl, A. Org. Lett. 2009, 11, 2449-2452. doi:10.1021/OI900681b

118.Sperger, C. A.; Fiksdahl, A. J. Org. Chem. 2010, 75, 4542-4553. doi:10.1021/Jo100712d

119.Meng, J.; Zhao, Y.-L.; Ren, C.-Q.; Li, Y.; Li, Z.; Liu, Q. Chem.-Eur. J. 2009, 15, 1830-1834. doi:10.1002/chem.200802304

120.Sperger, C.; Strand, L. H. S.; Fiksdahl, A. Tetrahedron 2010, 66, 7749-7754. doi:10.1016/j.tet.2010.07.071

121.Cheong, P. H.-Y.; Morganelli, P.; Luzung, M. R.; Houk, K. N.; Toste, F. D. J. Am. Chem. Soc. 2008, 130, 4517-4526. doi:10.1021/Ja711058f

122. Imase, H.; Noguchi, K.; Hirano, M.; Tanaka, K. Org. Lett. 2008, 10 , 3563-3566. doi:10.1021/OI801466f

123.Lee, Y. T.; Kang, Y. K.; Chung, Y. K. J. Org. Chem. 2009, 74, 7922-7934. doi:10.1021/Jo901771p

124.Barabé, F.; Bétournay, G.; Bellavance, G.; Barriault, L. Org. Lett. 2009, 11, 4236-4238. doi:10.1021/O1901722q

125.Michon, C.; Liu, S. Y.; Hiragushi, S.; Uenishi, J.; Uemura, M. Tetrahedron 2008, 64, 11756-11762. doi:10.1016/j.tet.2008.09.086

126. Jiménez-Núñez, E.; Molawi, K.; Echavarren, A. M. Chem. Commun. 2009, 7327-7329. doi:10.1039/B920119j
127.Amijs, C. H. M.; López-Carrillo, V.; Raducan, M.; Pérez-Galán, P.; Ferrer, C.; Echavarren, A. M. J. Org. Chem. 2008, 73, 7721-7730. doi:10.1021/Jo8014769

128.Schelwies, M.; Moser, R.; Dempwolff, A. L.; Rominger, F.; Helmchen, G. Chem.-Eur. J. 2009, 15, 10888-10900. doi:10.1002/chem.200901614

129.Porcel, S.; López-Carrillo, V.; García-Yebra, C.; Echavarren, A. M. Angew. Chem., Int. Ed. 2008, 47, 1883-1886. doi:10.1002/anie. 200704500

130.Zhu, L.-L.; Wang, Y.-H.; Zhang, Y.-X.; Li, X.-X.; Liu, H.; Chen, Z. J. Org. Chem. 2011, 76, 441-449. doi:10.1021/Jo1018014

131.Miege, F.; Meyer, C.; Cossy, J. Org. Lett. 2010, 12, 4144-4147. doi:10.1021/OI101741f

132.Sanz, R.; Miguel, D.; Rodríguez, F. Angew. Chem., Int. Ed. 2008, 47, 7354-7357. doi:10.1002/anie.200802660

133.Barluenga, J.; Piedrafita, M.; Ballesteros, A.; Suárez-Sobrino, A. L.; González, J. M. Chem.-Eur. J. 2010, 16, 11827-11831. doi:10.1002/chem.201001754

134.Ferrer, C.; Escribano-Cuesta, A.; Echavarren, A. M. Tetrahedron 2009, 65, 9015-9020. doi:10.1016/j.tet.2009.08.067

135. Gronnier, C.; Odabachian, Y.; Gagosz, F. Chem. Commun. 2011, 47, 218-220. doi:10.1039/C0cc00033g

136. Park, C.; Lee, P. H. Org. Lett. 2008, 10, 3359-3362. doi:10.1021/OI801196g

137. Balamurugan, R.; Gudla, V. Org. Lett. 2009, 11, 3116-3119. doi:10.1021/OI900863d

138. Tarselli, M. A.; Gagné, M. R. J. Org. Chem. 2008, 73, 2439-2441. doi:10.1021/Jo7024948

139. Kong, W.; Fu, C.; Ma, S. Eur. J. Org. Chem. 2010, 6545-6555. doi:10.1002/ejoc.201001112

140.Jurberg, I. D.; Gagosz, F. J. Organomet. Chem. 2011, 696, 37-41. doi:10.1016/j.jorganchem.2010.06.017

141.Hashmi, A. S. K.; Rudolph, M.; Huck, J.; Frey, W.; Bats, J. W.; Hamzić, M. Angew. Chem., Int. Ed. 2009, 48, 5848-5852. doi:10.1002/anie.200900887

142. Bhunia, S.; Liu, R.-S. J. Am. Chem. Soc. 2008, 130, 16488-16489. doi:10.1021/Ja807384a

143.Zhou, J. Chem.-Asian J. 2010, 5, 422-434. doi:10.1002/asia.200900458

144. Chen, Y.; Li, G.; Liu, Y. Adv. Synth. Catal. 2011, 353, 392-400. doi:10.1002/adsc.201000644

145. Chen, Y.; Lu, Y.; Li, G.; Liu, Y. Org. Lett. 2009, 11, 3838-3841. doi:10.1021/OI901408u

146. Lu, Y.; Du, X.; Jia, X.; Liu, Y. Adv. Synth. Catal. 2009, 351, 1517-1522. doi:10.1002/adsc.200900068

147.Zhang, Q.; Cheng, M.; Hu, X.; Li, B.-G.; Ji, J.-X. J. Am. Chem. Soc. 2010, 132, 7256-7257. doi:10.1021/ja101804p

148. Barluenga, J.; Fernández-Rodríguez, M. A.; García-García, P.; Aguilar, E. J. Am. Chem. Soc. 2008, 130, 2764-2765. doi:10.1021/ja7112917

149. Li, C.-J.; Trost, B. M. Proc. Natl. Acad. Sci. U. S. A. 2008, 105, 13197-13202. doi:10.1073/pnas.0804348105

150. Hirano, K.; Inaba, Y.; Takahashi, N.; Shimano, M.; Oishi, S.; Fujii, N.; Ohno, H. J. Org. Chem. 2011, 76, 1212-1227. doi:10.1021/jo102507c

151.Dudnik, A. S.; Schwier, T.; Gevorgyan, V. Org. Lett. 2008, 10, 1465-1468. doi:10.1021/ol800229h

152. Jin, T.; Yamamoto, Y. Org. Lett. 2008, 10, 3137-3139. doi:10.1021/OI801265s

153.Liu, Y.; Qian, J.; Lou, S.; Xu, Z. J. Org. Chem. 2010, 75, 6300-6303. doi:10.1021/Jo101357d 
154.Ueda, M.; Sato, A.; Ikeda, Y.; Miyoshi, T.; Naito, T.; Miyata, O Org. Lett. 2010, 12, 2594-2597. doi:10.1021/OI100803e

155.Liu, L.; Zhang, J. Angew. Chem., Int. Ed. 2009, 48, 6093-6096. doi:10.1002/anie.200901628

156. Hirano, K.; Inaba, Y.; Watanabe, T.; Oishi, S.; Fujii, N.; Ohno, H. Adv. Synth. Catal. 2010, 352, 368-372. doi:10.1002/adsc.200900880

157.Kothandaraman, P.; Rao, W.; Foo, S. J.; Chan, P. W. H. Angew. Chem., Int. Ed. 2010, 49, 4619-4623. doi:10.1002/anie.201000341

158. Hopkinson, M. N.; Tessier, A.; Salisbury, A.; Giuffredi, G. T.; Combettes, L. E.; Gee, A. D.; Gouverneur, V. Chem.-Eur. J. 2010, 16, 4739-4743. doi:10.1002/chem.201000322

159. García-García, P.; Fernández-Rodríguez, M. A.; Aguilar, E. Angew. Chem., Int. Ed. 2009, 48, 5534-5537. doi:10.1002/anie.200901269

160.Liu, Y.; Xu, W.; Wang, X. Org. Lett. 2010, 12, 1448-1451. doi:10.1021/OI100153h

161.Zhou, Y.; Zhai, Y.; Ji, X.; Liu, G.; Feng, E.; Ye, D.; Zhao, L.; Jiang, H.; Liu, H. Adv. Synth. Catal. 2010, 352, 373-378. doi:10.1002/adsc.200900724

162.Feng, E.; Zhou, Y.; Zhang, D.; Zhang, L.; Sun, H.; Jiang, H.; Liu, H. J. Org. Chem. 2010, 75, 3274-3282. doi:10.1021/jo100228u

163.Zhou, Y.; Li, J.; Ji, X.; Zhou, W.; Zhang, X.; Qian, W.; Jiang, H.; Liu, H. J. Org. Chem. 2011, 76, 1239-1249. doi:10.1021/jo101727r

164.Zhou, Y.; Ji, X.; Liu, G.; Zhang, D.; Zhao, L.; Jiang, H.; Liu, H. Adv. Synth. Catal. 2010, 352, 1711-1717. doi:10.1002/adsc.201000199

165.Patil, N. T.; Mutyala, A. K.; Lakshmi, P. G. V. V.; Gajula, B.; Sridhar, B.; Pottireddygari, G. R.; Rao, T. P. J. Org. Chem. 2010, 75, 5963-5975. doi:10.1021/jo1013228

166.Zhou, Y.; Feng, E.; Liu, G.; Ye, D.; Li, J.; Jiang, H.; Liu, H. J. Org. Chem. 2009, 74, 7344-7348. doi:10.1021/Jo901418m

167.Zhang, G.; Cui, L.; Wang, Y.; Zhang, L. J. Am. Chem. Soc. 2010, 132, 1474-1475. doi:10.1021/Ja909555d

168.Brenzovich, W. E.; Benitez, D.; Lackner, A. D.; Shunatona, H. P.; Tkatchouk, E.; Goddard, W. A., III; Toste, F. D. Angew. Chem., Int. Ed. 2010, 49, 5519-5522. doi:10.1002/anie.201002739

169.Ball, L. T.; Green, M.; Lloyd-Jones, G. C.; Russell, C. A. Org. Lett. 2010, 12, 4724-4727. doi:10.1021/Ol1019162

170. Melhado, A. D.; Brenzovich, W. E.; Lackner, A. D., Jr.; Toste, F. D. J. Am. Chem. Soc. 2010, 132, 8885-8887. doi:10.1021/Ja1034123

171.Jadhav, A. M.; Bhunia, S.; Liao, H.-Y.; Liu, R.-S. J. Am. Chem. Soc. 2011, 133, 1769-1771. doi:10.1021/ja110514s

172. Hopkinson, M. N.; Ross, J. E.; Giuffredi, G. T.; Gee, A. D.; Gouverneur, V. Org. Lett. 2010, 12, 4904-4907. doi:10.1021/ol102061k

173.Suárez-Pantiga, S.; Rubio, E.; Alvarez-Rúa, C.; González, J. M. Org. Lett. 2009, 11, 13-16. doi:10.1021/ol8025523

174.Barluenga, J.; Fernández, A.; Rodríguez, F.; Fañanás, F. J. Chem.-Eur. J. 2009, 15, 8121-8123. doi:10.1002/chem.200901557

175.Ding, C.-H.; Hou, X.-L. Chem. Rev. 2011, 111, 1914-1937. doi:10.1021/cr100284m

176.Monge, D.; Jensen, K. L.; Franke, P. T.; Lykke, L.; Jørgensen, K. A. Chem.-Eur. J. 2010, 16, 9478-9484. doi:10.1002/chem.201001123

177.Matsumoto, Y.; Selim, K. B.; Nakanishi, H.; Yamada, K.; Yamamoto, Y.; Tomioka, K. Tetrahedron Lett. 2010, 51, 404-406. doi:10.1016/j.tetlet.2009.11.039
178.LaLonde, R. L.; Wang, Z. J.; Mba, M.; Lackner, A. D.; Toste, F. D. Angew. Chem., Int. Ed. 2010, 49, 598-601.

doi:10.1002/anie.200905000

179. Murai, M.; Uenishi, J.; Uemura, M. Org. Lett. 2010, 12, 4788-4791. doi:10.1021/OI1019376

180.Wang, C.; Han, Z.-Y.; Luo, H.-W.; Gong, L.-Z. Org. Lett. 2010, 12, 2266-2269. doi:10.1021/Ol1006086

181.Chao, C.-M.; Vitale, M. R.; Toullec, P. Y.; Genêt, J.-P.; Michelet, V. Chem.-Eur. J. 2009, 15, 1319-1323. doi:10.1002/chem.200802341

182. Bandini, M.; Eichholzer, A. Angew. Chem., Int. Ed. 2009, 48, 9533-9537. doi:10.1002/anie.200904388

183.Bandini, M.; Gualandi, A.; Monari, M.; Romaniello, A.; Savoia, D.; Tragni, M. J. Organomet. Chem. 2011, 696, 338-347. doi:10.1016/j.jorganchem.2010.09.065

184. Chao, C. M.; Beltrami, D.; Toullec, P. Y.; Michelet, V. Chem. Commun. 2009, 6988-6990. doi:10.1039/B913554e

185.Zhou, G.; Liu, F.; Zhang, J. Chem.-Eur. J. 2011, 17, 3101-3104. doi:10.1002/chem.201100019

186. Sethofer, S. G.; Mayer, T.; Toste, F. D. J. Am. Chem. Soc. 2010, 132, 8276-8277. doi:10.1021/Ja103544p

187. Uemura, M.; Watson, I. D. G.; Katsukawa, M.; Toste, F. D. J. Am. Chem. Soc. 2009, 131, 3464-3465. doi:10.1021/Ja900155x

188. Kleinbeck, F.; Toste, F. D. J. Am. Chem. Soc. 2009, 131, 9178-9179. doi:10.1021/Ja904055z

189. Liu, F.; Yu, Y.; Zhang, J. Angew. Chem., Int. Ed. 2009, 48, 5505-5508. doi:10.1002/anie.200901299

190.Martínez, A.; García-García, P.; Fernández-Rodríguez, M. A.; Rodríguez, F.; Sanz, R. Angew. Chem., Int. Ed. 2010, 49, 4633-4637. doi:10.1002/anie.201001089

191. Muratore, M. E.; Holloway, C. A.; Pilling, A. W.; Storer, R. I.; Trevitt, G.; Dixon, D. J. J. Am. Chem. Soc. 2009, 131, 10796-10797. doi:10.1021/ja9024885

\section{License and Terms}

This is an Open Access article under the terms of the Creative Commons Attribution License (http://creativecommons.org/licenses/by/2.0), which permits unrestricted use, distribution, and reproduction in any medium, provided the original work is properly cited.

The license is subject to the Beilstein Journal of Organic Chemistry terms and conditions:

(http://www.beilstein-journals.org/bjoc)

The definitive version of this article is the electronic one which can be found at: $\underline{\text { doi: } 10.3762 / \text { bjoc. } 7.103}$ 